HOOFDSTUK IX

\title{
Het conflict tussen Nederland en de Republiek Indonesië \\ Laatste fase \\ Het geschil over Nieuw-Guinea
}

\section{Inleiding en overzicht}

Toen het Koninkrijk der Nederlanden zijn soevereiniteit over het voormalige Nederlands-Indië op 27 december 1949 overdroeg aan de Republiek der Verenigde Staten van Indonesië, leek er een waardig einde gekomen te zijn aan het drama dat begonnen was met de Indonesische onafhankelijkheidsproclamatie van 17 augustus 1945. In Amsterdam liet het carillon van het paleis op de Dam het Indonesia Raja horen. In Indonesië voltrok de bestuursoverdracht zich overal ordelijk. Tussen de soldaten van het Republikeinse leger en de Nederlandse militairen bleek weinig vijandigheid te bestaan. Ondanks de strijd van de afgelopen jaren beschikte Nederland nog over veel goodwill in zijn vroegere kolonie. Binnen Nederland zelf stond het merendeel van de bevolking welwillend tegenover het onafhankelijke Indonesië. Men kon dus denken 'eind goed, al goed'.

Maar het was het einde van het drama nog niet en het ging niet goed. Er volgde nog een laatste bedrijf, waarin de verstandhouding tussen Indonesië en Nederland volledig verstoord werd. Dat laatste bedrijf duurde bijna driemaal zo lang als alle bedrijven tussen 1945 en 1949 bij elkaar.

$\mathrm{Al}$ in de loop van het eerste jaar leed het vertrouwen in de wederpartij zowel aan Nederlandse als aan Indonesische kant ernstige schade. Aan Nederlandse kant was dat allereerst een reactie op de Indonesische acties tot ontmanteling van de federale staatsstructuur, die op 17 augustus 1950 uitmondden in vervanging van de Verenigde Staten van Indonesië door een unitaire Republiek Indonesië. De in 1949 op de Rondetafelconferentie overeengekomen federale structuur had voor veel Nederlanders de kern gevormd van het compromis 
tussen Nederland enerzijds en Soekarno's Republiek anderzijds. Daarom zagen zij de opheffing van die structuur als een flagrante contractbreuk. Het leek zelfs alsof alle Nederlandse inspanningen en offers in de strijd tegen Jogja voor niets geweest waren.

Intussen hadden opstandige Indonesiërs op Ambon een Republiek der Zuid-Molukken (RMS) uitgeroepen, die in september-november 1950 door de Indonesische strijdkrachten gewelddadig onderdrukt werd. Ook deze onderdrukking deed ernstige afbreuk aan het vertrouwen in het nieuwe Indonesië bij een deel van het Nederlandse publiek. Veel Nederlanders geloofden dat Ambon zich nauw met Nederland verbonden voelde en daarom buiten de nieuwe Indonesische staat wilde blijven. Sympathie voor de underdog vermengde zich bij hen met gevoelens van schuld jegens het Ambonese volk dat, naar zij meenden, door Nederland in de steek gelaten was.

Omgekeerd leidde de Nederlandse sympathie voor de RMS aan Indonesische kant juist tot ondermijning van het vertrouwen in Nederland. Veel Indonesiërs legden verband tussen de uitroeping van de RMS en enkele andere in 1950 tegen het centrale gezag ondernomen acties, in het bijzonder een mislukte aanslag op Bandung en een mislukte muiterij in Makassar. Men zag hierin vooral machinaties van koloniaalgezinde Nederlanders die het onafhankelijke Indonesië probeerden te ontwrichten.

Veel groter schade aan het Indonesische vertrouwen in Nederland werd eind 1950 aangericht door de Nederlandse weigering tot overdracht van westelijk Nieuw-Guinea. Het ging nu immers niet om de houding van individuele Nederlanders maar om de opstelling van de Nederlandse regering en het Nederlandse parlement. De op de Rondetafelconferentie voor de duur van een jaar gemaakte uitzondering voor Nieuw-Guinea was in Indonesië algemeen opgevat als een tijdelijke kunstgreep, die nodig geweest was om in het Nederlandse parlement de vereiste twee derde meerderheid voor de soevereiniteitsoverdracht te verkrijgen. Dat Nederland nu ondanks het verstrijken van die termijn Nieuw-Guinea bleef vasthouden ervoer men als een flagrante schending van het gegeven woord.

Indonesiërs konden zich volstrekt niet vinden in de Nederlandse redenering dat Nieuw-Guinea eigenlijk niet bij Indonesië hoorde. Met het kaartbeeld van de kolonie Nederlands-Indië waren zij allen vertrouwd. De Nederlandse weigering om Nieuw-Guinea over te dragen betekende een forse verminking van dat kaartbeeld. Weliswaar hadden de contacten tussen dat eiland en de rest van de kolonie zich vroeger meestal tot de Molukken beperkt, maar het koloniale regime had toen politieke tegenstanders uit de hele archipel binnen Nieuw-Guinea geïnterneerd. Ook had de nationale vrijheidsbeweging het Indonesië waarvoor zij onafhankelijkheid verlangde steeds omschreven als 'van Sabang tot Merauke'.

Men kon de Indonesische motieven voor het opeisen van Nieuw-Guinea 
wel afdoen als meer van psychologische dan van zakelijke aard, maar hetzelfde gold in veel sterkere mate voor de Nederlandse motieven om NieuwGuinea vast te houden. Die motieven waren vooral een reactie op de snelle dekolonisatie van Nederlands-Indië. Daarbij valt te bedenken dat de psychologische betekenis van Indonesië voor Nederland veel groter geweest was dan die van bijvoorbeeld India voor Groot-Brittannië of van Indochina voor Frankrijk. Terwijl het in 1945 voor de meeste Nederlanders nog vanzelf sprak dat Indonesië bij Nederland hoorde, had de dekolonisatie zich daarna in enkele jaren voltrokken. Die abrupte verandering had voor veel Nederlanders een traumatische ervaring betekend, vooral voor hen die gewend waren de band met 'Indië' als een bestanddeel van hun nationale identiteit te zien. In die kring kon het vasthouden van Nieuw-Guinea enigszins als pleister op de wonde dienen. Men stelde zich dan voor dat dit vrijwel ongerepte gebied nog een arbeidsveld voor Nederlandse ondernemingsgeest en Nederlands roepingsbesef kon worden en dat Nederland door het behoud van een presentie in Azië toch nog een zekere rol op het wereldtoneel zou kunnen spelen.

De wens om Nieuw-Guinea van de overdracht aan Indonesië uit te zonderen bestond in 1949 alleen bij een minderheid van de Nederlandse politici, al was deze minderheid sterk genoeg om een twee derde meerderheid voor een ongeclausuleerde soevereiniteitsoverdracht te kunnen blokkeren. Enkele jaren later ontwikkelde deze wens zich echter tot een meerderheidspositie in de Nederlandse binnenlandse politiek. In 1954 waren bijna alle partijen het er over eens, dat de soevereiniteit over westelijk Nieuw-Guinea bij Nederland berustte en moest blijven berusten totdat de bevolking van het gebied in staat zou zijn zelf over haar staatkundig lot te beschikken, dat er geen sprake kon zijn van onderhandelingen met Indonesië over de toekomstige status van het gebied en dat Nederland geen enkele vorm van gemengd bestuur of gedeelde verantwoordelijkheid voor het gebied zou mogen aanvaarden.

De officiële vertegenwoordigers van Nederland in Djakarta waarschuwden herhaaldelijk dat alle Nederlandse invloed in Indonesië verloren dreigde te gaan als Nederland op het punt van Nieuw-Guinea onbuigzaam bleef. In de loop der jaren werd in Nederland ook herhaaldelijk van niet-politieke kant aangedrongen op wijziging van het Nieuw-Guineabeleid, onder meer uit kerkelijke kring en uit de hoek van de Nederlandse ondernemers. Het mocht allemaal niet baten. Onder de Nederlandse politici overheerste de mening dat, als men moest kiezen tussen het behoud van Nieuw-Guinea en het behoud van goede betrekkingen met Indonesië, de keus op Nieuw-Guinea moest vallen.

De goede betrekkingen van Nederland met Indonesië bleven dan ook niet in stand. De samenwerking in het kader van de Indonesisch-Nederlandse Unie kwam niet van de grond. De Nederlandse taal raakte binnen enkele jaren buiten gebruik. In 1956 zegde Indonesië de Unie eenzijdig op. Eind 1957 begon in Indonesië een intimidatiecampagne tegen Nederlandse ingezetenen 
die ertoe leidde dat de grote meerderheid van hen het land verliet. In diezelfde periode stelde de Indonesische regering de Nederlandse bedrijven onder beheer; eind 1958 volgde de nationalisatie ervan. In mei 1960 drongen demonstranten in Djakarta het gebouw van de Nederlandse vertegenwoordiging binnen, waar ze de inventaris vernielden en de Nederlandse vlag verbrandden. Enige maanden later verbrak Indonesië de diplomatieke betrekkingen met Nederland. In het kader van de dekolonisatie na de Tweede Wereldoorlog is het nergens ter wereld tot zo'n volledige breuk tussen een voormalige kolonie en het voormalige moederland gekomen als tussen Indonesië en Nederland. Pas jaren later, toen het geschil over Nieuw-Guinea tot het verleden behoorde, bleek tussen de beide landen toch een verstandhouding zonder vijandschap mogelijk.

Bij de langdurige Nederlandse onwil om Indonesië op het punt van NieuwGuinea tegemoet te komen vallen twee kanttekeningen te maken.

Ten eerste was de Indonesische eis tot overdracht van westelijk NieuwGuinea van begin af aan in vormen gegoten die in Nederland averechts werkten. Onafgebroken stelde Soekarno het voor alsof zijn land met geen groter probleem te kampen had dan de voortgezette Nederlandse aanwezigheid in dat gebied. Al sinds 1950 dreigden Indonesische politici met represailles tegen Nederlanders en tegen Nederlandse ondernemingen als Nederland aan Nieuw-Guinea bleef vasthouden. Die dreigementen werden in de volgende jaren veelvuldig herhaald en tenslotte in 1957 en 1958 in daden omgezet. Dit maakte het voor Nederland steeds moeilijker om Indonesië ter wille te zijn, omdat niemand graag de indruk wekt voor chantage te wijken.

Ten tweede maakte Indonesië sinds 1950 een binnenlands-politieke ontwikkeling door die het Nederlandse vertrouwen in de leiding van dat land sterk verminderde. Daartoe behoorde ook de berechting van enige Nederlanders op basis van evident valse beschuldigingen. Intussen ontwikkelde de communistische partij zich tot de best georganiseerde politieke beweging van het land en keerde Soekarno zich tegen de op westerse normen gebaseerde democratie. In die situatie leek het moeilijk met de Nederlandse verantwoordelijkheid te rijmen om de bevolking van Nieuw-Guinea aan dit onberekenbare regime over te dragen.

Uiteindelijk ging Nederland daar in 1962 toch toe over, zij het via een korte tussenfase onder bestuur van de Verenigde Naties. Indonesië had inmiddels een grote strijdmacht opgebouwd die het voor de bevrijding van NieuwGuinea dreigde in te zetten. Nederland zou het gebied niet hebben kunnen verdedigen. Het was aan de Amerikaanse regering te danken dat Nederland in staat werd gesteld om nog met enig gezichtsbehoud het gebied los te laten. 


\section{De politieke situatie na de soevereiniteitsoverdracht}

Nederland had op 27 december 1949 zijn soevereiniteit over Indonesië overgedragen aan de Republiek der Verenigde Staten van Indonesië (RVI). In de eerste weken van 1950 heerste hier in het algemeen een vreedzame en ontspannen sfeer. Bijna iedereen was opgelucht dat de oorlog voorbij was. Aan de Indonesische bevolking gaf het grote voldoening dat Nederland zijn koloniaal gezag had opgegeven en de onafhankelijkheid van Indonesië had erkend. De tijdens en na de Rondetafelconferentie (RTC) gepleegde nauwe samenwerking tussen de Republiek en de BFO wettigde de hoop dat de tegenstelling tussen unitarisme en federalisme in de RVI geen bron van grote conflicten hoefde te zijn. De Nederlandse Hoge Commissaris, H.M. Hirschfeld, onderhield uitstekende betrekkingen met de regering van de RVI. De Nederlandse ondernemers (de 'planters') verwachtten hun werk op de ondernemingen grotendeels op de oude voet te kunnen voortzetten of hervatten op basis van de in de RTC overeengekomen garanties. Van de Nederlandse ambtenaren, die nu door de RTC-akkoorden RVI-ambtenaren geworden waren, hoopten velen dat de nieuwe heersers nog een tijd lang van hun deskundigheid gebruik zouden willen maken. De in de afgelopen jaren uit Nederland naar Indonesië overgebrachte militairen waren blij naar huis te kunnen terugkeren. Overigens bleek tussen deze militairen en de soldaten van de oude Republiek verrassend weinig vijandigheid te bestaan.

De soevereiniteitsoverdracht bevatte weliswaar één manco: de voorlopige handhaving van het Nederlandse bestuur over Nieuw-Guinea, maar daarover maakte men zich geen ernstige zorgen. Men wist dat deze uitzondering nodig geweest was om in het Nederlandse parlement de vereiste twee derde meerderheid te verkrijgen, maar ook dat was afgesproken de kwestie nog in 1950 op te lossen. De verwachting was wijdverbreid, ook onder Nederlanders in Indonesië, dat Nieuw-Guinea dan alsnog overgedragen zou worden.

Het hierboven geschetste beeld van vredigheid en ontspanning was niet in alle opzichten maatgevend. Zo bestonden er aan Indonesische kant nog zowel ultra-linkse als islamitische strijdgroepen die niet bereid waren zich aan het gezag van Soekarno en Hatta te onderwerpen. De 'Indische Nederlanders' (personen van gemengd Europees-Aziatische afstamming die onder het koloniale bestel de status van 'Europeanen' genoten hadden) zagen hun eigen toekomst met zorg tegemoet. Zij verloren hun bevoorrechte positie, maar kregen nog twee jaar de tijd om voor het Nederlandse dan wel het Indonesische staatsburgerschap te opteren; deden zij het eerste dan zouden ze vreemdelingen in eigen land worden. Zij maakten zich bovendien zorgen over hun persoonlijke veiligheid in het licht van het geweld waaraan hun bevolkingsgroep tijdens de bersiap-periode had blootgestaan. Wat de blanke Nederlanders betreft waren er twee groepen wier bestaan zo nauw met het koloniale bestel verweven was 
dat de soevereiniteitsoverdracht hen eigenlijk van hun bestaansgrond beroofde: de bestuursambtenaren en de KNIL-officieren. Een deel van hen koesterde nog steeds kolonialistische denkbeelden. Deze koloniaal-conservatieven vonden dat de inheemse bevolking van Indonesië onvoldoende capabel was om een moderne samenleving te laten functioneren en daarom Nederlandse leiding nodig had. Zij hadden weinig begrip voor het Indonesisch nationalisme en schreven alle inheemse steun voor de Republiek toe aan misleiding, intimidatie en terreur. Zij meenden dat Nederland in december 1948 een klinkende overwinning op de Republiek behaald had en vonden het daarom absurd dat de regering binnen een jaar Indonesië alsnog had prijsgegeven aan Soekarno. In de loop van 1950 vertrokken ongeveer vijftigduizend Nederlandse burgers uit Indonesië naar Nederland; een flink deel hiervan behoorde tot de hier genoemde groepen.

Van de Nederlandse bestuursambtenaren maakten velen op grond van hun opleiding en ervaring nog wel kans op een nieuwe werkkring in Nederland zelf. Voor de Nederlandse KNIL-officieren stond de mogelijkheid open naar de Nederlandse landmacht over te gaan. Hetzelfde gold in beginsel voor de Nederlandse onderofficieren in het KNIL (onder wie vooral Indische Nederlanders). Daarentegen waren de Indonesische KNIL-militairen in een moeilijke positie beland nu in de RTC was overeengekomen het KNIL medio 1950 op te heffen. Op grond van de in Den Haag genomen besluiten konden deze militairen nog slechts kiezen tussen twee mogelijkheden: hetzij overgaan naar de strijdkrachten van de RVI, hetzij de dienst verlaten en een andere broodwinning zoeken.

Het besluit tot opheffing van het KNIL had deze militairen ernstig geschokt. Zij waren er in de voorgaande jaren steeds van uitgegaan dat het KNIL de kern zou vormen van het leger van het toekomstige onafhankelijke Indonesië. Dat vertegenwoordigers van de deelstaten al in juli-augustus 1949 hadden ingestemd met de wens van de Republiek, dat niet het KNIL maar de TNI de kern van dat leger zou vormen (zie p. 646), was de meesten ontgaan. Vervolgens had het overleg over militaire onderwerpen in de RTC in Den Haag zich in volstrekte geheimhouding voltrokken. Pas na de RTC werd bekend dat het KNIL zou verdwijnen. Overigens was ook ten tijde van de soevereiniteitsoverdracht nog niet geregeld onder welke voorwaarden KNIL-militairen zouden kunnen overstappen naar de nieuwe strijdmacht, de Angkatan Perang Republik Indonesia Serikat (APRIS, Strijdkrachten van de Republiek der Verenigde Staten van Indonesië). Voor veel Indonesische KNIL-militairen was het psychologisch moeilijk om naar de APRIS over te gaan, omdat die nu eenmaal in meerderheid uit hun vroegere vijanden bestond. Bovendien was het onzeker of zij als voormalige dienaren van het koloniaal gezag binnen de APRIS wel welkom zouden zijn.

Voor geen groep gold dit alles in sterkere mate dan voor de Molukse KNIL- 
militairen, meestal 'Ambonezen' genoemd. Vooral veel christelijke Ambonezen voelden zich sterk met het Nederlandse gezag, de Nederlandse vlag en het Nederlandse koningshuis verbonden. Al generaties lang hadden velen van hen voor een loopbaan in het koloniale leger gekozen. In dat leger waren zij dikwijls juist voor de gevaarlijkste opdrachten ingezet. Eind 1948 hadden Ambonezen bijvoorbeeld nog een belangrijk aandeel gehad in de spectaculaire verovering van Jogja. Door het geheel buiten hen om genomen besluit van de Nederlandse regering tot ontbinding van het KNIL voelden de Ambonese KNIL-militairen zich dan ook bij uitstek in de steek gelaten.

\section{De APRA-affaire}

De vredige sfeer na de soevereiniteitsoverdracht werd op maandagochtend 23 januari 1950 ruw verstoord. Uit de westelijk van Bandung gelegen garnizoensplaats Tjimahi trokken toen ruim driehonderd geüniformeerde strijders de stad binnen, schoten op alle TNI-militairen die ze zagen en bezetten enige gebouwen, waaronder het hoofdkwartier van de Siliwangidivisie. Deze strijders, in meerderheid Ambonezen, bleken volgelingen te zijn van de voormalige KNIL-officier Westerling. De verovering van het hoofdkwartier had hun weinig moeite gekost omdat daar in hoofdzaak administratief personeel aanwezig was; de elite-eenheden van de Siliwangidivisie bevonden zich niet in Bandung maar in Djakarta.

Als kapitein van het KNIL had Westerling eind 1946 met een speciale eenheid een meedogenloze terreurcampagne in Zuid-Celebes gevoerd ter onderdrukking van het anti-koloniale verzet (zie pp. 517-8). Zijn eenheid was later uitgebreid tot een Korps Speciale Troepen (KST) van ruim achthonderd man. Onder de leden van dat korps was Westerling uitzonderlijk populair, maar in november 1948 had de legerleiding hem van het commando daarover ontheven. Daarna had hij het KNIL verlaten en was hij directeur geworden van een particulier transportbedrijf in West-Java. In 1949 reisde hij hier veel rond en onderhield hij allerlei contacten, onder meer met vroegere KST-collega's, met hooggeplaatste KNIL-officieren en ook met Indonesische politici. Nadat in mei het akkoord tussen Rum en Van Roijen de weg had vrijgemaakt voor terugkeer van de leiders van de Republiek naar Jogja, begon Westerling plannen te smeden voor de vorming van een strijdgroep die overheersing van Indonesië door Soekarno en Hatta zou moeten voorkomen. Hij noemde die strijdgroep Angkatan Perang Ratu Adil (APRA, Strijdkrachten van de Rechtvaardige Vorst), aanknopend bij de oude Djojobojo-legende die voorspelde dat op Java na allerlei rampspoed een rechtvaardige vorst zou komen die vrede en voorspoed brengen zou (zie pp. 56-7). Eind 1949 gingen steeds meer geruchten over deze APRA de ronde doen. Haar aanhang zou vooral 
uit ontevreden KNIL-militairen bestaan. De leiding van de Republiek maakte zich hier zorgen over, vooral voor het geval zo'n anti-Republikeins leger zou gaan samenwerken met de Darul Islam die al sommige delen van West-Java beheerste en zich uiterst vijandig tegenover de Republiek opstelde. Haar leider, Kartosuwirjo, had in augustus definitief met de Republiek gebroken door een Negara Islam Indonesia (Islamitische Indonesische Staat) uit te roepen. De situatie in West-Java werd nog verder gecompliceerd door het optreden van een strijdgroep van volgelingen van Tan Malaka onder leiding van Chaerul Saleh die de RTC-akkoorden afwees.

Op 5 januari 1950 richtte Westerling een ultimatum tot de regering van de RVI en de regering van de deelstaat Pasundan, waarin hij eiste dat de APRA als het eigen leger van Pasundan erkend zou worden tenzij de RVI binnen een week maatregelen tegen de TNI zou nemen. Namens de Nederlandse regering nam Hirschfeld scherp afstand van dit ultimatum. De Nederlandse legerleiding maakte bekend dat desertie van onder Nederlands bevel staande soldaten streng zou worden bestraft. Het ultimatum verstreek overigens zonder dat er iets gebeurde.

Toen APRA-aanhangers op 23 januari een overval op Bandung pleegden, vreesden velen dat Westerling alsnog een burgeroorlog in West-Java zou ontketenen. Hatta pleegde onmiddellijk overleg met Hirschfeld; de Nederlandse regering liet weten dat zij bereid was de RVI-regering militair bij te staan. De overvallers bestonden voornamelijk uit KST-militairen en uit voormalige KNIL-soldaten die al naar de APRIS overgegaan waren. Al spoedig bleek echter dat hun actie weinig om het lijf had. Zij wisten niet wat ze verder moesten doen en lieten zich nog dezelfde middag door hoge KNIL-officieren overhalen om hun avontuur te beëindigen en de bezette gebouwen te verlaten. De gedeserteerde militairen keerden grotendeels naar hun kampementen terug, waar ze werden ontwapend en in hechtenis genomen. Intussen brachten Nederlandse militaire vliegtuigen soldaten van de Siliwangidivisie naar Bandung over. Het APRA-avontuur had het leven gekost aan drieënnegentig TNI-militairen en zes burgers.

Westerling zelf had in het voorafgaande weekeinde wel aan de voorbereiding van de overval deelgenomen, maar was zondagavond naar Djakarta vertrokken. Het was zijn bedoeling geweest ook daar een machtsgreep te ondernemen en de RVI-regering uit te schakelen, maar van dit plan kwam niets terecht, onder meer omdat de samenzweerders geen beschikking kregen over de wapens waarop ze gerekend hadden. Na de mislukte machtsgreep in Bandung bleef Westerling wekenlang onvindbaar, maar eind februari dook hij plotseling in Singapore op. Het bleek dat hij Indonesië met hulp van Nederlandse officieren had kunnen verlaten.

De KNIL-militairen die aan de aanslag op Bandung deelgenomen hadden kwamen er minder goed af. Midden 1950 veroordeelde de Nederlandse krijgs- 
raad honderdvierentwintig van hen wegens desertie tot gevangenisstraffen van maximaal een jaar, waartoe ze naar Nieuw-Guinea werden overgebracht.

Hoewel de Nederlandse regering zich in de APRA-affaire duidelijk achter de regering van de RVI gesteld had, werd de Indonesisch-Nederlandse verstandhouding door de aanslag op Bandung en de nasleep ervan ernstig geschaad. De affaire bevestigde het vermoeden, dat een deel van de Nederlanders in Indonesië de soevereiniteitsoverdracht afkeurde en ongelukkig was over de overheersende positie van de Republikeinse leiders binnen de RVI. Onder die Nederlanders had Westerling kennelijk aanmoediging en steun gekregen voor zijn subversieve activiteiten. Het wekte extra ergernis dat Nederlandse officieren ook na de mislukte aanslag op Bandung geholpen hadden om hem het land uit te werken en aan de Indonesische justitie te onttrekken. Blijkbaar was men aan Nederlandse kant diep bezorgd over de onthullingen die Westerling zou kunnen doen als hij in Indonesië terecht moest staan. Een andere grond voor Indonesische ergernis en teleurstelling was het leedvermaak waarmee een deel van het Nederlandse publiek op de affaire reageerde. Veel Nederlanders vonden het prachtig dat de APRA in Bandung de TNI vernederd had en bewonderden als een heldendaad wat in feite een even brute als klungelige actie geweest was.

Tot de nasleep van de affaire behoorde ook dat de Indonesische politie een groot aantal personen arresteerde die van medeplichtigheid aan de activiteiten van Westerling verdacht werden. De meeste Nederlanders onder de gearresteerden kwamen weer spoedig vrij, maar sommigen bleven tot 1953 in hechtenis.

\section{Ontmanteling van de federale staatsstructuur}

Het was een onderdeel van de RTC-overeenkomst dat de nieuwe Republiek, waaraan Nederland zijn soevereiniteit over Indonesië overdroeg en waarvan het de onafhankelijkheid erkende, een federale staat zou zijn. De samenstellende delen van die federatie werden in de voorlopige constitutie van de RVI opgesomd. Het waren er zestien in totaal, zeven deelstaten en negen autonome gebieden. Deze federale structuur was zowel onevenwichtig als gecompliceerd: onevenwichtig wegens enorme onderlinge verschillen in bevolkingsomvang en grondgebied, gecompliceerd wegens diverse onderlinge verschillen in bevoegdheden en organisatie.

De Nederlandse regering had in haar conflict met de oorspronkelijke Republiek van 1946 af het standpunt ingenomen, dat een onafhankelijk Indonesië alleen maar goed zou kunnen functioneren als het een federatie vormde. Hoe dit uitgangspunt te rijmen viel met het feit dat Nederland zelf de kolonie Nederlands-Indië altijd unitaristisch bestuurd had legde de regering 
niet uit. Wat de vorm van die federatie betreft had Van Mook oorspronkelijk gepleit voor een verdeling in vier grote deelstaten, Java, Sumatra, Borneo en Oost-Indonesië. In het akkoord van Linggadjati van eind november 1946 had ook de Republiek aanvaard dat Indonesië een federatie zou worden, en wel in de vorm van drie deelstaten, de Republiek zelf (die Java en Sumatra zou omvatten), Borneo en Oost-Indonesië. Maar naast de Republiek en OostIndonesië stichtte het Nederlands-Indische gouvernement in 1948-1949 nog veertien andere deelstaten en autonome gebieden, waarvan zes op grondgebied dat volgens het akkoord van Linggadjati onder de Republiek zou vallen. Meer en meer deed men het van Nederlandse kant voorkomen alsof het bij de dekolonisatie van Indonesië niet ging om een conflict tussen Nederland en de Republiek, maar om een interne tegenstelling binnen Indonesië tussen unitaristen en federalisten.

De federale conceptie was op zichzelf niet onverenigbaar met het Indonesische onafhankelijkheidsstreven. In de jaren twintig hadden verscheidene nationalisten, onder wie ook Hatta en Soekarno, een federaal Indonesië voorgestaan. Pas tijdens de Japanse bezetting ontwikkelde zich een duidelijke voorkeur voor de unitaire staatsvorm (zie p. 342). Daarna was de federale staatsvorm nog veel sterker in diskrediet geraakt toen Nederland de keuze tussen eenheidsstaat en bondsstaat tot een keuze voor of tegen de Republiek maakte.

$\mathrm{Na}$ de soevereiniteitsoverdracht openbaarde zich in Indonesië een wijdverbreide weerzin tegen handhaving van de federale staatsstructuur. Velen zagen de lappendeken van deelstaten en autonome gebieden vooral als een product van Nederlandse verdeel-en-heers-politiek. Het verzet hiertegen werd onder meer uitgedragen door Republikeinse militairen die uit de guerrillagebieden terugkeerden. Al in januari kwamen in verscheidene steden comités tot stand die opriepen tot herstel van de eenheidsstaat.

Begin januari had Westerling te kennen gegeven dat hij met zijn APRA de deelstaat Pasundan wilde beschermen tegen overheersing door de Republiek van Jogja. Het resultaat van de aanslag op Bandung was precies het omgekeerde. Al twee dagen daarna werden twee ministers van deze deelstaat gearresteerd op verdenking van samenspanning met de aanslagplegers. Op 27 januari zei het parlement van Pasundan zijn vertrouwen in het deelstaatkabinet op en sprak het zich uit voor overdracht van het bestuur aan de centrale regering. De president van Pasundan, Wiranatakusuma, legde kort daarna zijn functie neer; ook hij bleek met Westerling gesproken te hebben.

Van februari tot april groeide de agitatie voor herstel van de eenheidsstaat uit tot een politieke storm. In bijna alle federale gebieden vonden massabetogingen plaats die de vertegenwoordigende lichamen van deze gebieden onder druk zetten om hun autonome status op te heffen. De heftigheid van die agitatie riep herinneringen aan de bersiap-tijd op (zie pp. 399-403). Zo 
moesten leden van vertegenwoordigende lichamen zich soms een weg banen door een tierende menigte demonstranten voordat ze de vergadering konden bereiken waarin de kwestie aan de orde zou komen. De minister van binnenlandse zaken van de centrale regering, Anak Agung, die voor de soevereiniteitsoverdracht premier van Oost-Indonesië en vice-voorzitter van de BFO geweest was, wilde zich niet inspannen voor behoud van de federale structuur voorzover die niet levensvatbaar was. Op 8 maart kondigde de regering een noodwet af die voor federale gebieden de mogelijkheid opende zich bij andere federale gebieden aan te sluiten. Op basis hiervan sloot het merendeel van die gebieden zich in de volgende weken aan bij de deelstaat Republiek Indonesië (de Jogjase Republiek). Deze aansluitingen werden telkens door het parlement van de RVI bekrachtigd. Begin april bestonden er naast de Jogjase Republiek nog maar drie andere federale gebieden, Oost-Indonesië, Oost-Sumatra en West-Borneo.

Op 5 april werd bekendgemaakt dat het hoofd van West-Borneo, sultan Hamid II van Pontianak, gearresteerd was wegens samenspanning met Westerling. Hamid, die voorzitter van de BFO geweest was en in het KNIL de rang van generaal-majoor bekleedde, had verwacht in de RVI minister van defensie te worden of een andere belangrijke functie te krijgen. Tot zijn teleurstelling was hij alleen minister zonder portefeuille geworden, terwijl Anak Agung wel een belangrijke plaats in de centrale regering kreeg. Volgens na zijn arrestatie in de pers verschenen berichten zou Hamid met Westerling hebben afgesproken dat deze het kabinet-Hatta gewapenderhand zou uitschakelen, waarna er een nieuwe centrale regering zou moeten komen waarin Hamid wel een zware functie zou vervullen en overheersing van Indonesië door de TNI zou tegenhouden. Het bericht over de arrestatie van Hamid leidde in West-Borneo tot versterkte agitatie voor aansluiting bij de Jogjase Republiek. Op 15 april werd ook deze aansluiting door het RVI-parlement bekrachtigd.

\section{Mislukte muiterij in Makassar}

Van alle door het Nederlands-Indische gouvernement opgerichte deelstaten leek de eind 1946 gevormde staat Oost-Indonesië het meest stevig gevestigd. In tegenstelling tot de andere federale gebieden was de vorming ervan uitdrukkelijk in het akkoord van Linggadjati voorzien; het was dan ook de enige deelstaat die door de Republiek formeel erkend was. Ook zijn territoriale omvang was uitzonderlijk: Celebes plus de Kleine Sunda-eilanden plus de Molukken. Hiertoe behoorden onder meer de twee Indonesische gebieden die het meest Nederlands-georiënteerd waren: Ambon en de Minahasa (waarvan de bevolking Menadonezen genoemd werd). Daar stond tegenover dat Oost-Indonesië ook een lange geschiedenis van verzet tegen de Nederlandse overheersing 
kende en dat sommige delen ervan pas na 1900 volledig onder Nederlands gezag gebracht waren: Zuid-Celebes, Midden-Celebes en de eilanden Bali, Ceram, Sumbawa en Flores (zie pp. 123-8). Bovendien waren niet alleen veel KNIL-militairen maar ook verscheidene prominente Republikeinse politici van Ambonese of Menadonese afkomst.

Sommige leidende Oost-Indonesische politici wilden de deelstaat graag handhaven. Dit gold onder meer voor de president van Oost-Indonesië, de Balinese aristocraat Sukawati, en ook voor zijn schoonzoon Anak Agung, die tot eind 1949 premier van Oost-Indonesië geweest was en nu in de centrale RVI-regering minister van binnenlandse zaken was. Een bijzonder felle antiRepublikein was de Ambonees Chris Soumokil; in de deelstaat Oost-Indonesië was hij procureur-generaal, minister van justitie en waarnemend premier geweest, maar sinds de laatste kabinetsformatie maakte hij geen deel meer van de regering uit. Hij zag nog liever dat Oost-Indonesië uit de RVI zou treden dan dat het in de Jogjase Republiek zou opgaan. Daarentegen telde het OostIndonesische parlement een aanzienlijk aantal leden die geen bezwaar hadden tegen een unitaire staatstructuur voor Indonesië.

Een belangrijk verschil van de situatie in Oost-Indonesië met die in de meeste andere federale gebieden was dat zich hier geen militairen bevonden van de TNI, het Republikeinse leger, maar wel een groot aantal militairen uit het KNIL, het koloniale leger. Intussen kwam in de eerste maanden van 1950 de overgang van KNIL-militairen naar de nieuwe federale strijdmacht, de APRIS, geleidelijk op gang. Eind januari werd bekend gemaakt dat het KNIL op 26 juli ontbonden zou worden. De meeste KNIL-militairen in OostIndonesië waren wel bereid naar de APRIS over te gaan, mits ze in dit gebied gelegerd zouden blijven. Zo ging eind maart in Makassar een KNIL-compagnie naar het federale leger over die geleid werd door kapitein Andi Abdul Aziz. Hij was op Celebes geboren maar in Nederland opgegroeid en had daar tijdens de Duitse bezetting aan het verzet deelgenomen.

Evenals in de hoofdplaatsen van andere federale gebieden werd in maart in Makassar gedemonstreerd voor aansluiting bij de Republiek. Daar stond tegenover dat hier ook demonstraties voor handhaving van de deelstaat plaatsvonden. De spanning in de stad steeg, onder meer door de komst van enige officieren uit Java die een territoriaal APRIS-commando voor Oost-Indonesië moesten opzetten. De Oost-Indonesische regering had eind december met de regering van de RVI afgesproken dat geen APRIS-eenheden zonder haar instemming in Oost-Indonesië gelegerd zouden worden. Niettemin werd begin april bekend dat een uit voormalige TNI-soldaten bestaand APRIS-bataljon in twee schepen onderweg was naar Makassar. Onder de voorstanders van handhaving van de deelstaat wekte dit grote ongerustheid, omdat TNI-eenheden in andere federale gebieden hun positie gebruikt hadden om kracht bij te zetten aan de beweging voor de eenheidsstaat. Soumokil, die kort daarvoor weer tot 
procureur-generaal van Oost-Indonesië benoemd was, besloot zich hiertegen te verzetten en kreeg hierbij steun van Sukawati en Aziz.

Op 5 april 1950 bezette Aziz met zijn compagnie en met steun van een paar honderd KNIL-militairen verschillende strategische punten in Makassar en het kantoor van de uit Java overgekomen APRIS-officieren, terwijl Soumokil een aantal voorstanders van aansluiting bij de Republiek liet arresteren. Aziz verklaarde dat het hem er alleen om te doen was ontscheping van het bataljon voormalige TNI-soldaten te beletten. Op het eerste gezicht leek zijn actie het gevaar in te houden dat Oost-Indonesië zich los zou maken van de RVI. Maar wat de RVI-regering vreesde en wat Aziz hoopte gebeurde niet: de Oost-Indonesische regering stelde zich niet achter zijn actie, zijn voorbeeld leidde niet tot muiterijen elders in Oost-Indonesië en ook in Makassar zelf steunde de meerderheid van de KNIL-militairen hem niet. Op 11 april riep de RVI-regering Aziz op binnen twee dagen naar Djakarta te komen om zich te verantwoorden; zij zond daartoe een vliegtuig naar Makassar en beloofde hem een vrijgeleide.

Toen Aziz hier niet op inging hield president Soekarno op 13 april een dreigend getoonzette radiorede; daarin noemde hij hem nooit bij naam maar sprak hij telkens over 'die jonge officier wiens naam ik niet zal uitspreken'. Zijn rede eindigde met een bevel aan de strijdkrachten om aan de opstand een eind te maken. De volgende dag vloog Aziz op aandrang van Sukawati alsnog naar Djakarta; hij dacht dat zijn vrijgeleide verlengd was, maar werd bij aankomst meteen gevangen genomen. Het APRIS-bataljon ging bij Makassar aan land; de volgelingen van Aziz gaven zich binnen enkele dagen over. Dit bataljon bestond overigens geheel uit soldaten van Oost-Indonesische afkomst. Soumokil had Makassar intussen verlaten. Op 25 april zei het parlement van Oost-Indonesië op voorstel van een Ambonees parlementslid het vertrouwen in de Oost-Indonesische regering op. Er werd een nieuwe regering gevormd onder een pro-Republikeinse premier. Evenals Westerling in januari had Aziz met zijn actie het omgekeerde bewerkstelligd van wat hij beoogd had.

\section{Uitroeping van de Republiek der Zuid-Molukken}

Het eiland Ambon in de Zuid-Molukken was het eerste gebied in Indonesië geweest waar de Nederlanders zich vestigden, nadat zij daar in 1605 op aandrang van inheemse hoofden de Portugezen hadden verdreven (zie p. 27). Die hoofden hadden zich toen bij verdrag tot eeuwige trouw aan Nederland verbonden en een flink deel van de bevolking was tot het christendom overgegaan. Eeuwenlang waren mannen uit Ambon als soldaten in Nederlandse dienst getreden. Men placht niet alleen de bevolking van Ambon zelf maar ook die van de naburige Zuid-Molukse eilanden als 'Ambonezen' te betitelen. 
Sinds de negentiende eeuw waren veel Ambonezen naar andere delen van Indonesië getrokken, niet alleen als militairen maar onder meer ook als ambtenaren en onderwijzers. Ten tijde van de soevereiniteitsoverdracht bevonden tienduizenden Ambonezen zich buiten de Zuid-Molukken; een aanzienlijk deel van hen was niet in de Molukken geboren en opgegroeid.

Traditioneel plachten veel Ambonezen zich te zien als steunpilaren van het Nederlandse gezag. Dit gold in het bijzonder voor de Ambonese KNILmilitairen. Na 1945 was op Java in Ambonese kring maar met steun van Nederlandse officieren een anti-Republikeinse organisatie opgericht, de Persatoean Timoer Besar (PTB, Vereniging Grote Oost), die ernaar streefde de Molukken af te scheiden van de rest van Indonesië onder behoud van een nauwe band met Nederland (zie pp. 657-8). Daarentegen steunden veel Ambonese intellectuelen de Indonesische vrijheidsbeweging en speelden sommige Ambonezen een belangrijke rol in de Republiek, zoals Johannes Leimena, leider van de protestants-christelijke partij Parkindo en minister van volksgezondheid in de RVI-regering. Er bestond zelfs een Ambonees legeronderdeel binnen de TNI: het Pattimura-bataljon, genoemd naar een ZuidMolukse opstandeling uit het begin van de negentiende eeuw (zie pp. 78-9).

In de eerste maanden van 1950 heerste op het eiland Ambon geen eensgezindheid over de toekomst van de Zuid-Molukken. De PTB had er enige aanhang, maar ook een Republikeinsgezinde partij was er actief en de meeste leden van de Zuid-Molukkenraad steunden het separatistische streven niet. Eén van de meest anti-Republikeinse leden van die Raad was J.A. Manusama, een uit Java afkomstige Ambonees die in 1947 hoofd van een middelbare school op Ambon geworden was. De separatistische gelederen werden begin 1950 versterkt doordat het KNIL een aantal Molukse militairen in afwachting van hun demobilisatie naar Ambon overbracht. Daardoor bevonden zich nu ruim tweeduizend KNIL-militairen op het eiland, waaronder een bewapende KST-compagnie.

In april raakte de politieke ontwikkeling op Ambon in een stroomversnelling als gevolg van de muiterij in Makassar. Op 18 april leidde Manusama een massabetoging waarin hij zich fel keerde tegen het streven naar een Indonesische eenheidsstaat. Hij deed een beroep op de regering van Oost-Indonesië om zich tegen de vorming daarvan te verzetten en zo nodig een onafhankelijke staat Oost-Indonesië te stichten. Intussen bevond zich op Ambon ook Soumokil; hij had Makassar na de mislukking van de muiterij tijdig kunnen verlaten. Het werd al spoedig duidelijk dat de Oost-Indonesische regering niet van plan was zich tegen de RVI te keren. Met steun van KST-militairen wisten Manusama en Soumokil nu de voorzitter van de Zuid-Molukkenraad, J.H. Manuhutu, te bewegen tot het proclameren van een onafhankelijke Republik Maluku Selatan (RMS, Republiek der Zuid-Molukken). De proclamatie vond op 24 april plaats en kreeg een geestdriftig onthaal bij een deel van de Ambonese 
bevolking. Er werd een regering gevormd met Manuhutu als president en Soumokil als minister van buitenlandse zaken.

De RVI-regering probeerde in eerste aanleg langs vreedzame weg aan de Ambonse rebellie een eind te maken. Zij zond eind april per schip een verzoeningsmissie naar Ambon onder leiding van minister Leimena. KST-militairen verhinderden echter contact tussen deze missie en de leiders van de RMS. Wel konden enige honderden Nederlanders midden mei Ambon per schip verlaten, samen met bijna tweehonderd KNIL-militairen die niet aan de rebellie mee wilden doen. De andere Molukse KNIL-militairen hadden intussen hun Nederlandse officieren ontwapend en formeel hun dienstverband met het KNIL opgezegd.

\section{Opheffing van het KNIL}

Volgens de militaire bepalingen van de Rondetafelconferentie (zie p. 655) zouden de uit Nederland naar Indonesië gezonden landstrijdkrachten zo mogelijk binnen zes maanden gerepatrieerd worden. De Nederlandse KNIL-militairen zouden deels kunnen overgaan naar de Nederlandse landmacht (officieel Koninklijke Landmacht geheten, afgekort KL) en deels de dienst moeten verlaten. De Indonesische KNIL-militairen zouden deels kunnen overgaan naar de strijdkrachten van de RVI (de APRIS) en deels eveneens de dienst moeten verlaten. Zes maanden na bekendmaking van de voorwaarden voor overgang naar de APRIS zou het KNIL ophouden te bestaan. De wapens, uitrusting, gebouwen en terreinen van het KNIL zouden aan de RVI worden overgedragen. De Nederlandse marine zou binnen een jaar uit Indonesië worden teruggetrokken, maar zou in die tijd nog taken voor de RVI blijven verrichten; ook zou Nederland een aantal marineschepen aan de RVI overdragen. Verder zou een Nederlandse militaire missie in Indonesië behulpzaak zijn bij de opbouw en opleiding van de strijdkrachten van de RVI.

In de jaren 1945-1949 had Nederland ruim honderdtwintigduizend KL-militairen naar Indonesië overgebracht. Ten tijde van de soevereiniteitsoverdracht waren hiervan de oorlogsvrijwilligers en het grootste deel van de 7 December-divisie al gerepatrieerd en bevonden zich nog ruim zeventigduizend KL-militairen in Indonesië. Nederland beschikte niet over voldoende eigen scheepsruimte om dit aantal binnen zes maanden af te voeren en moest daarom buitenlandse scheepsruimte huren; hierdoor konden bijna al deze militairen nog voor september 1950 Indonesië verlaten.

Op 26 januari 1950 maakte de RVI-regering de voorwaarden voor overgang naar de APRIS bekend. Dit bracht mee dat de Nederlandse regering het KNIL per 26 juli 1950 moest opheffen.

Het KNIL omvatte ten tijde van de soevereiniteitsoverdracht ongeveer 65.000 
man, van wie 15.000 de Nederlandse nationaliteit en 50.000 de Indonesische nationaliteit bezaten. Bijna 8000 van de Nederlandse KNIL-militairen gingen over naar de KL en vertrokken naar Nederland (waar velen van hen nog nooit geweest waren; dit betrof vooral Indo-Europeanen). Van de 50.000 Indonesische KNIL-militairen bestond de meerderheid uit Javanen en ongeveer een vijfde deel uit Ambonezen en Menadonezen. Uiteindelijk zijn ongeveer 26.000 van hen naar de APRIS overgegaan, maar voor een deel gebeurde dat pas na de opheffing van het KNIL. De KNIL-militairen die de dienst verlieten hadden op grond van een vooroorlogse regeling er recht op te worden gedemobiliseerd op een plaats van hun keuze binnen Indonesië. De belangrijkste KNIL-militair die naar de APRIS overging was de Ambonese luitenant-kolonel Julius Tahija. Hij had in de Tweede Wereldoorlog aan de strijd tegen Japan deelgenomen, had de Nederlandse delegatie geadviseerd in de conferentie op de Hoge Veluwe, was adjudant van generaal Spoor geweest en had als lid van de BFO-delegatie de Rondetafelconferentie bijgewoond. Hij wist veel KNIL-militairen ertoe over te halen de overstap naar de APRIS te wagen en het was vooral aan zijn invloed te danken dat de meeste Ambonese militairen in Makassar zich in april afzijdig hielden van de muiterij van kapitein Aziz.

Toen in juli 1950 de datum naderde waarop het KNIL opgeheven zou worden, stond echter voor een deel van de Indonesische KNIL-militairen nog niet vast of ze de militaire dienst zouden verlaten dan wel naar de APRIS zouden overgaan. In een aantal gevallen hadden zij zelf nog niet definitief gekozen, in andere gevallen hadden zij wel gekozen maar had de Indonesische overheid daar nog geen beslissing op genomen. Zoals eerder vermeld vonden vooral veel Ambonese militairen het moeilijk om naar de APRIS over te gaan. De problemen werden nog veel groter na de proclamatie van de Republiek der Zuid-Molukken. Een deel van die militairen verlangde nu op Ambon gedemobiliseerd te worden.

Omdat het onmogelijk was deze problemen voor de opheffingsdatum op te lossen kwamen de Nederlandse en de Indonesische regering overeen, dat de nog niet overgegane of gedemobiliseerde KNIL-militairen met ingang van 24 juli 1950 tijdelijk de status van KL-militair zouden krijgen. Deze militairen en hun gezinnen werden in doorgangskampen op Java ondergebracht. Enige honderden Nederlandse KL-militairen zouden nog tot uiterlijk eind december in Indonesië kunnen blijven om die kampen te beveiligen.

\section{Herstel van de Indonesische eenheidsstaat}

Van de vijftien federale gebieden die de RVI ten tijde van de soevereiniteitsoverdracht telde naast de Jogjase Republiek sloten dertien zich voor het eind van april bij die Republiek aan (zie p. 695). De twee toen resterende gebieden 
waren Oost-Indonesië en Oost-Sumatra. De president van Oost-Indonesië, Sukawati, voelde er niet voor zijn deelstaat in de Jogjase Republiek te laten opgaan, maar na de onderdrukking van de muiterij in Makassar verklaarde hij wel te willen meewerken aan de vestiging van een Indonesische eenheidsstaat, mits zijn deelstaat daarbij op dezelfde voet zou worden behandeld als die Republiek. De president van Oost-Sumatra, Mansur, die zich in 1948 en 1949 scherp tegenover de Republiek opgesteld had, sloot zich hierbij aan. Begin mei kwamen Sukawati en Mansur met Hatta overeen, dat hun deelstaten samen met de Jogjase Republiek de nieuwe eenheidsstaat zouden stichten; zij machtigden Hatta om hun deelstaten te vertegenwoordigen bij het daartoe met Jogja te voeren overleg.

Ter voorbereiding van de eenheidsstaat werd een commissie ingesteld die in de eerste plaats een nieuwe grondwet moest ontwerpen. Voorzitter werd de RVI-minister van justitie, Supomo, die ook een belangrijk aandeel had gehad in de opstelling van zowel de Republikeinse grondwet van 1945 als de federale grondwet van 1949. Men had het zich nu eenvoudig kunnen maken door uit die laatste grondwet alleen die bepalingen te schrappen die op de federale staatstructuur betrekking hadden, maar zo eenvoudig ging het niet. De commissie verdiepte zich ook uitvoerig in allerlei andere aspecten van het nieuwe staatsbestel. Na ruim twee maanden bereikte ze overeenstemming over een ontwerp dat gedeeltelijk aan de grondwetten van 1945 en 1949 ontleend was en gedeeltelijk nieuw geformuleerd was. Zo keerde het recht op onderwijs, dat in de eerste grondwet uitdrukkelijk erkend was maar in de RVI-grondwet niet meer voorkwam, weer in de oude formulering terug. De nieuwe eenheidsstaat zou 'Republiek Indonesië' heten, precies zoals de in augustus 1945 gevormde staat. Evenals de grondwetten van 1945 en 1949 zou de nieuwe grondwet slechts een voorlopig karakter dragen, maar de grondwet van 1950 onderstreepte dit door zich uitdrukkelijk 'Voorlopige grondwet' te noemen. Bovendien bepaalde ze dat de definitieve grondwet zou worden vastgesteld door een 'Konstituante' waarvan de leden door de Indonesische onderdanen in algemene, vrije en geheime verkiezingen zouden worden gekozen.

De commissie behandelde verder ook enige andere kwesties, zoals de samenstelling van het nieuwe parlement en de verdeling van het grondgebied van de eenheidsstaat in provincies. In de tweede week van augustus werd de nieuwe staatsinrichting met ruime meerderheden goedgekeurd door het parlement van de RVI en door het Werkcomité van het KNIP (het voorlopige parlement van de Jogjase Republiek). Op 17 augustus 1950, de vijfde verjaardag van de onafhankelijkheidsproclamatie, maakte Soekarno bekend dat de RVI plaats had gemaakt voor een nieuwe unitaire Republiek Indonesië. Soekarno en Hatta bleven president en vicepresident, maar Hatta zou zijn functie van minister-president neerleggen. De voorzitter van de Masjumi, Mohammad Natsir, kreeg opdracht een nieuw kabinet te vormen. 
De transformatie van de RVI in de nieuwe Republiek Indonesië had voor de Indonesiërs een betekenis die verder reikte dan de vraag of hun staat beter in provincies dan in deelstaten verdeeld kon worden. Dat laatste was een kwestie waar men verschillend over kon denken, maar het stond buiten twijfel dat de federale structuur van de RVI een Nederlandse schepping geweest was. De Nederlandse soevereiniteitsoverdracht aan die RVI had het onafhankelijke Indonesië daardoor met een koloniale erfenis belast. Ook Indonesiërs die geen vurige voorstanders van een unitaire staatsstructuur waren konden daarom in de opheffing van deze federale structuur een voltooiing zien van de Indonesische vrijheidsstrijd.

In Nederland viel de transformatie van de RVI in een nieuwe unitaire Republiek daarentegen buitengewoon slecht. Men kon wel betogen, zoals Hirschfeld deed, dat dit een interne kwestie van het soevereine Indonesië was die men eenvoudig had te accepteren, maar de meeste Nederlanders zagen het anders. Voor hen was de federale staatsvorm geen zaak waar Indonesië vrij over kon beslissen, maar een centraal bestanddeel van het akkoord tussen Nederland en de oude Republiek dat ten grondslag lag aan de RTCovereenkomst. Dat akkoord had zware Nederlandse concessies ingehouden: aanvaarding dat Indonesië onafhankelijk zou worden met Soekarno als president en met de Jogjase republiek als machtigste bestanddeel. Daar hadden (afgezien van de kwestie-Nieuw-Guinea) twee belangrijke Republikeinse concessies tegenover gestaan: aanvaarding dat het onafhankelijke Indonesië een federale staat zou zijn en aanvaarding dat Indonesië en Nederland samen een Unie zouden vormen onder de Nederlandse koningin. Die twee zaken waren trouwens al in 1946 in het akkoord van Linggadjati neergelegd en Nederland had ze bovendien in 1948 in zijn eigen grondwet verankerd (zie p. 582). Omdat de federale structuur een basiselement van de RTC-overeenkomst vormde, zagen veel Nederlanders in de opheffing van die structuur een flagrante contractbreuk. Sommigen verdachten de leiders van de Republiek ervan tijdens de RTC vals spel gespeeld te hebben en slechts in schijn met de federale structuur te hebben ingestemd om er na de soevereiniteitsoverdracht zo gauw mogelijk van af te komen. Men kon moeilijk geloven dat het herstel van de eenheidsstaat een onontkoombare tegemoetkoming aan een spontane volksbeweging geweest was; er waren aanwijzingen dat de agitatie in de eerste maanden van 1950 van bovenaf gedirigeerd was en dat actievoerders soms intimiderend waren opgetreden.

Hoewel het niet vreemd is dat het herstel van de Indonesische eenheidsstaat door velen in Nederland als een contractbreuk beschouwd werd, kan men de intensiteit van de daar gevoelde verontwaardiging en frustratie moeilijk begrijpen als men alleen naar de zaak kijkt waar het formeel om ging, namelijk de vraag of Indonesië beter in deelstaten dan in provincies verdeeld kon worden. Dit was immers een kwestie waar Nederland geen enkel zakelijk 
belang bij had. In de Nederlandse politiek had deze kwestie echter een betekenis gekregen die daar ver bovenuit ging.

Tijdens het conflict met de Republiek had Nederland in alle delen van Indonesië die weer onder Nederlands gezag kwamen te staan Indonesiërs gevonden die bereid waren dit gezag te erkennen en op die basis met Nederland samen te werken. Samen met zulke coöperatieve Indonesiërs had Nederland een reeks autonome gebieden en deelstaten opgericht, eerst buiten Java en Sumatra en later ook binnen die eilanden zelf. Uiteindelijk had het de Republiek zelf niet kunnen uitschakelen, maar het had zich gericht op het bereiken van een compromis waardoor er in het onafhankelijke Indonesië niet alleen voor Republikeinse nationalisten een rol weggelegd zou zijn maar ook voor Indonesiërs die het Nederlandse gezag hadden willen erkennen. De in de RTC bevestigde federale staatsstructuur had hier de belangrijkste waarborg voor moeten vormen. Daarom leek dit compromis door de staatkundige metamorfose van 17 augustus 1950 kapot te zijn gemaakt. De federalisten waren uitgeschakeld en Nederland zag zich net als in 1945 weer geplaatst tegenover een unitaire Republiek Indonesië onder Soekarno en Hatta. Het leek wel alsof alle inspanningen en offers die Nederland zich sindsdien getroost had vruchteloos geweest waren.

\section{Herovering van Ambon}

De uitroeping op Ambon van een Republiek der Zuid-Molukken (RMS) op 24 april 1950 had in Nederland terstond positieve reacties gewekt. Daarbij deed zich opnieuw het merkwaardige fenomeen voor dat juist die Nederlanders die bij hoog en bij laag het recht van het Indonesische volk ontkend hadden om zich van Nederland af te scheiden en over zijn eigen lot te beschikken zich nu vurige pleitbezorgers toonden van het recht van het Ambonese volk op afscheiding en zelfbeschikking. Oud-premier Gerbrandy, nu lid van het parlement, vergeleek de opstand van Ambon tegen Djakarta zelfs met de strijd van de Nederlanders tegen Spanje in de zestiende eeuw.

In dit verband is het nuttig er aan te herinneren dat in 1946 onder leiding van Gerbrandy een Nationaal Comité Handhaving Rijkseenheid was opgericht dat ernaar streefde Indonesië binnen het Koninkrijk der Nederlanden te houden (zie p. 510). Toen het medio 1949 duidelijk werd dat de afscheiding van Indonesië niet viel tegen te houden, had dit Comité zich ingespannen om toch nog het meest oostelijke deel van de archipel daarvan uit te zonderen en in een bijzonder verband met Nederland onder te brengen (zie p. 658). Daartoe voerde het onder meer een grote propaganda-actie waarin vertegenwoordigers van separatistische organisaties zoals de PTB verklaarden dat de volken van de Minahasa, de Molukken en Timor buiten de nieuwe Indonesische staat wil- 
den blijven. Op een deel van het Nederlandse publiek had die actie zo'n diepe indruk gemaakt dat bijna een kwart miljoen Nederlanders een petitie ondertekende waarin gevraagd werd aan de eisen van de drie volken te voldoen. Uiteindelijk slaagde de actie niet en werden op grond van de RTC-overeenkomst ook deze gebieden deel van de RVI, terwijl alleen Nieuw-Guinea voorlopig bij Nederland bleef. In februari 1950 hief het Comité zich op, maar al in diezelfde tijd werd een nieuwe particuliere organisatie voorbereid die zich ten doel stelde de verwezenlijking te bevorderen van 'het zelfbeschikkingsrecht van de volken van Ambon, Timor en de Minahasa'. Deze organisatie kwam eind april formeel tot stand in de vorm van een stichting Door De Eeuwen Trouw. De naam verwees naar het verdrag van 1605 waarin inlandse hoofden op Ambon eeuwige trouw aan Nederland beloofd hadden. De Stichting stelde zich volledig achter de Ambonse rebellie.

De Indonesische regering probeerde die rebellie in de eerste plaats op te lossen door overleg met bemiddeling van nationalistische Ambonezen, maar dit mislukte. De regering was echter niet in staat op korte termijn gewapenderhand tegen de RMS op te treden, omdat daar een grootschalige amfibische operatie voor nodig was. De Republikeinse militairen hadden op dat gebied geen enkele ervaring en de voorbereiding van de beoogde operatie vergde veel tijd. Intussen stelde de Indonesische marine een blokkade van Ambon in om de bevolking onder druk te zetten. Als eerste fase van de militaire operatie bezetten regeringstroepen in juli delen van de naburige eilanden Buru en Ceram.

Er waren overigens in deze maanden heel andere zaken die in Djakarta de aandacht opeisten, waaronder allereerst de voorbereiding van de eenheidsstaat en vervolgens de vorming van een nieuwe centrale regering. De daartoe aangewezen kabinetsformateur Natsir presenteerde op 6 september het nieuwe kabinet. Rum werd minister van buitenlandse zaken en legde dus zijn functie neer als Indonesisch Hoge Commissaris in Nederland. Intussen had Hirschfeld, de eerste Nederlandse Hoge Commissaris in Indonesië, zijn taak eveneens beëindigd; hij werd eind september opgevolgd door de diplomaat A.Th. Lamping.

Op 28 september begon eindelijk de grote aanval op Ambon, die werd ingeleid met een luchtbombardement, terwijl de regeringstroepen op het noordelijk deel van het eiland landden. Deze poging om snel een eind aan de RMS te maken werd een fiasco. Zowel het weerstandsvermogen van de RMSstrijders als de steun die ze bij de bevolking genoten was in Djakarta volledig onderschat. De regeringstroepen kwamen vast te zitten en konden niet doordringen tot het zuidelijk deel van het eiland met de hoofdstad. Nadat uit Java versterkingen waren aangevoerd volgde op 3 november een nieuw offensief, waarbij regeringstroepen ook dicht bij de hoofdstad aan land gingen. Nu werd het verzet op Ambon in enkele dagen gebroken, maar de hoofstad was groten- 
deels verwoest. Manusama, Soumokil en andere RMS-leiders weken met een aantal strijders uit naar het binnenland van het eiland Ceram.

De Indonesische regering stelde zich tegenover de Ambonese bevolking verzoenend op. Gevangen genomen RMS-strijders werden niet als rebellen berecht, maar mochten alsnog toetreden tot het Indonesische leger. Ambtenaren die de kant van de RMS gekozen hadden konden hun functies meestal spoedig weer uitoefenen.

In Nederland was de strijd op Ambon met spanning gevolgd. Bij een deel van het publiek vermengde spontane sympathie voor de underdog zich met gevoelens van schuld tegenover het dappere Ambonese volk dat immers, naar men meende, door Nederland lelijk in de steek gelaten was. Het dagblad Trouw drong zelfs aan op inzet van de Nederlandse marine en luchtmacht om Ambon te hulp te komen. De Nederlandse regering wilde het conflict tussen Djakarta en de RMS liefst als een interne zaak zien waarmee ze geen bemoeienis had, maar de bombardementen van eind september wekten zoveel verontwaardiging dat premier Drees zich op 4 oktober genoodzaakt voelde een gebaar te maken. Dit gebaar had de vorm van een openbaar telegram aan premier Natsir, waarin Drees verklaarde dat de militaire actie niet alleen de regering maar het hele Nederlandse volk diep geschokt had en waarin hij er op aandrong de strijd te staken en naar een vreedzame oplossing te streven. Het telegram wekte woedende reacties in de Indonesische pers en het Indonesische parlement.

De stichting Door De Eeuwen Trouw was de spil van de solidariteit met Ambon. Onder meer zamelde ze geld in voor hulp aan de RMS, organiseerde ze protestvergaderingen en gaf ze een eigen orgaan uit met de titel De Stem van Ambon. Ook bevorderde ze een voor Nederland nieuwe strijdmethode, het forceren van politieke besluiten door juridische procedures. Zo spande een met de stichting verbonden advocaat in oktober namens de RMS een proces aan tegen de KPM, de Nederlandse scheepvaartonderneming die het vervoer in de Indonesische archipel verzorgde. Daarin werd geëist dat de KPM geen schepen meer beschikbaar zou stellen voor het vervoer van Indonesische troepen naar Ambon. In eerste instantie won de RMS het proces; enige maanden later werd deze uitspraak in hoger beroep ongedaan gemaakt.

\section{Impasse over Nieuw-Guinea}

Volgens het Charter van Souvereiniteitsoverdracht zou de staatkundige status van Nieuw-Guinea binnen een jaar na de soevereiniteitsoverdracht bepaald moeten worden door onderhandelingen tussen Indonesië en Nederland (zie p. 666). De eerste gelegenheid hiertoe deed zich voor toen in maart 1950 de eerste ministersconferentie in het kader van de Indonesisch-Nederlandse Unie 
plaatsvond. Op voorstel van minister Van Maarseveen besloot deze conferentie echter de onderhandelingen tot het najaar uit te stellen. Men hoopte dat na een half jaar rust het politieke klimaat gunstiger zou zijn voor het vinden van overeenstemming.

Deze verwachting kwam niet uit: een half jaar later was het politieke klimaat juist ernstig verslechterd. Onder indruk van de opheffing van de deelstaten en de strijd om Ambon stelde het Nederlandse publiek zich tegenover het nieuwe Indonesië veel minder welwillend op dan in het begin van het jaar. Daar droeg ook toe bij dat van de ongeveer vijftigduizend Nederlandse burgers die in de loop van het jaar uit Indonesië naar Nederland gemigreerd waren velen bitter gestemd waren jegens Soekarno en de zijnen. Hetzelfde gold voor het merendeel van de uit Indonesië gerepatrieerde Nederlandse militairen.

Overigens had de Nederlandse regering zelf sinds de soevereiniteitsoverdracht met medewerking van het parlement een aantal maatregelen ten aanzien van Nieuw-Guinea genomen die moeilijk te rijmen vielen met het voorlopige karakter van de in artikel 2 van het Charter overeengekomen regeling. Terwijl toen was afgesproken dat 'de status quo van de residentie' een jaar lang zou worden gehandhaafd, veranderde de regering de bestuursorganisatie van het gebied, verhoogde zij de staatsrechtelijke status ervan van een residentie tot een gouvernement, benoemde zij daarover een gouverneur en richtte zij nieuwe bestuurlijke diensten op. Verder voerde zij onder meer een afzonderlijke geldsoort in (met een afbeelding van koningin Juliana) en diende zij bij het parlement een driejarenbegroting voor Nieuw-Guinea in. Men kan stellen dat Nederland daarmee de eerste was om het Unieverdrag te schenden, zo al niet naar de letter dan toch naar de geest.

Intussen was het politieke klimaat ook aan Indonesische kant niet gunstiger geworden. De RMS-affaire leidde daar tot ongerustheid dat Nieuw-Guinea, als het in Nederlandse handen bleef, een uitvalsbasis kon worden voor tegen Djakarta gerichte acties in Oost-Indonesië. Maar ook los hiervan was de toekomst van Nieuw-Guinea in de loop van het jaar een steeds belangrijker prestigekwestie geworden. In al zijn toespraken hamerde Soekarno er op dat de revolutie nog niet voltooid was zolang Nieuw-Guinea niet met Indonesië herenigd was. Het Indonesische parlement stuurde in oktober een missie naar Nederland om het Indonesische standpunt toe te lichten, met als woordvoerder de radicale nationalist Muhammad Yamin (die al jarenlang betoogde dat Indonesië eigenlijk ook het grondgebied van Malakka, Singapore, Brits Borneo en Portugees Timor moest omvatten). Bij aankomst in Nederland zei hij dat het moeilijk zou worden de Nederlandse belangen in Indonesië veilig te stellen als de Nieuw-Guinea-kwestie niet voor 27 december geregeld zou zijn,. Kort daarna werd uit Indonesië vernomen dat Sutomo ('Bung Tomo'), een onder veel Nederlanders beruchte volksmenner uit de bersiap-tijd, met 
een economische boycot dreigde als Nederland zou weigeren het gebied over te dragen.

De speciale conferentie over Nieuw-Guinea begon in Den Haag op 4 december 1950. Rum leidde de Indonesische en Van Maarseveen de Nederlandse delegatie. Om te bereiken dat Nederland Nieuw-Guinea zou overdragen bood de regering-Natsir in deze conferentie vergaande tegemoetkomingen aan, waaronder erkenning van Nederlandse economische en financiële rechten, voorkeursbehandeling van Nederland bij nieuwe concessies en investeringen, toelating van Nederlandse werkkrachten en immigranten, garanties voor missie en zending en tenslotte autonomie voor de bevolking van het gebied. De regering-Drees meende echter zich volstrekt niet te kunnen veroorloven Nieuw-Guinea los te laten. Pas bij het naderen van de einddatum bood ze een concessie aan, namelijk dat Nederland de soevereiniteit over het gebied zou kunnen overdragen aan de Nederlands-Indonesische Unie, echter onder volledige handhaving van het Nederlandse bestuur en met uitzicht op zelfbeschikking voor de bevolking. Voor de Indonesische delegatie was dit onaanvaardbaar, zodat de conferentie op 27 december in een mislukking eindigde. Rum verklaarde dat, nu het in de RTC overeengekomen jaar van handhaving van de status quo in Nieuw-Guinea voorbij was, de voortzetting van die status quo niet meer de instemming van Indonesië had.

De mislukte conferentie had nog een belangrijk gevolg voor de langere termijn. De Nederlandse regering ging ervan uit dat voor verandering van de status van Nieuw-Guinea nog steeds een twee derde meerderheid in het parlement nodig was. Begin 1951 bleek dat ruim een derde deel van het parlement volstrekt wilde vasthouden aan de Nederlandse soevereiniteit over Nieuw-Guinea en zich ook verzette tegen eventuele overdracht van de soevereiniteit aan de Nederlands-Indonesische Unie. Bovendien bleek dat de minister van buitenlandse zaken, Stikker (die persoonlijk voor overdracht van Nieuw-Guinea aan Indonesië geweest was, maar daarin binnen de regering alleen had gestaan) niet langer het vertrouwen genoot van zijn eigen partij, de VVD. Stikker trad daarom af. Hierop volgde een kabinetscrisis van anderhalve maand. Midden maart trad een nieuw kabinet-Drees op, waarin ook Stikker weer terugkeerde. In zijn regeringsprogram verklaarde dit kabinet dat, omdat enerzijds voor geen enkele verandering van de status van Nieuw-Guinea een twee derde meerderheid in het Nederlandse parlement te vinden was en anderzijds de Republiek Indonesië niets minder wilde aanvaarden dan de volledige soevereiniteit over het gebied, de regering geen andere keus had dan de kwestie voorlopig te laten rusten. Zoals men het destijds placht aan te duiden, zette Nederland de kwestie voor onbepaalde tijd 'in de ijskast'. 


\section{Overbrenging van Ambonese ex-KNIL militairen naar Nederland}

Toen het KNIL op 26 juli 1950 ophield te bestaan, stond voor een deel van de Indonesische KNIL-militairen nog niet vast of zij de militaire dienst zouden verlaten dan wel naar het Indonesische leger zouden overgaan (zie p. 700). Als noodoplossing kregen deze militairen toen een tijdelijke KL-status. Vervolgens gingen ongeveer tienduizend van hen alsnog over naar de APRI (de nieuwe naam van het Indonesische leger na het herstel van de eenheidsstaat), terwijl ongeveer tienduizend zich op verschillende plaatsen binnen Indonesië lieten demobiliseren. Er bleef een groep van ongeveer vierduizend Ambonese militairen over die de kant van de RMS gekozen hadden en verlangden op Ambon gedemobiliseerd te worden. De Indonesische regering wilde dit niet toestaan zolang Ambon in opstand was. Intussen bevonden deze militairen en hun gezinnen zich in doorgangskampen op Java die tijdelijk beveiligd werden door Nederlandse soldaten.

Nadat de Indonesische regering in november haar gezag over Ambon hersteld had verklaarde zij geen bezwaar meer te hebben tegen demobilisatie van deze ex-KNIL-militairen op dit eiland. Maar nu wezen dezen dit zelf af, omdat zij daar represailles verwachtten wegens hun steun aan de RMS. Als alternatief stelden zij voor, hun groep hetzij naar Nieuw-Guinea over te brengen hetzij naar gebied in de Molukken dat nog in RMS-handen was. Ook hier kon noch de Nederlandse regering noch de Indonesische regering mee instemmen.

De Nederlandse regering spande zich in om deze ex-KNIL-militairen ertoe te bewegen zich toch te laten demobiliseren op Ambon of op ander gebied onder gezag van de Indonesische regering. Onder meer bood zij daartoe financiële tegemoetkomingen aan. Intussen hadden deze Ambonezen als hun vertegenwoordiger in Nederland de RMS-minister F.A. Aponno aangewezen, die zich sinds juni in dit land bevond en nauw contact onderhield met de stichting Door De Eeuwen Trouw. Toen de Ambonezen op Java zich eind november bijna lieten overhalen om binnen Indonesië de dienst te verlaten, gaf Aponno hun het dringende advies hiervan af te zien. Hij spande een proces aan tegen de Nederlandse staat met behulp van dezelfde Nederlandse advocaat die het proces tegen de KPM begonnen was. Van de rechter werd gevraagd de Nederlandse staat te verbieden om de Ambonese militairen tegen hun zin te demobiliseren in door de Indonesische regering beheerst gebied.

Op 21 december wees de Nederlandse rechter deze eis toe. De staat ging in beroep, maar verloor een maand later de zaak in hoger beroep. Demobilisatie in gebied onder Indonesisch gezag was daardoor uitgesloten. Demobilisatie op Nieuw-Guinea, zoals door Aponno verlangd, kwam evenmin in aanmerking. In deze situatie meende de Nederlandse regering geen andere keus te hebben dan de vierduizend Ambonese militairen samen met hun ruim achtduizend gezinsleden naar Nederland zelf over te brengen. Met de Indonesische rege- 
ring was intussen afgesproken dat de beveiliging door Nederlandse militairen van de kampen op Java nog enkele maanden voortgezet kon worden. Tussen februari en juni 1951 bracht men de twaalfduizend Ambonese mannen, vrouwen en kinderen in twaalf schepen naar Nederland over. De meesten werden daar gehuisvest in voormalige gevangenkampen die de Duitse bezettingsmacht er tijdens de Tweede Wereldoorlog had laten bouwen. Men ging er in Nederland van uit dat de overbrenging van deze gezinnen naar Europa slechts een tijdelijke noodsprong was in afwachting van een definitieve oplossing.

Intussen had de Nederlandse regering besloten de Ambonese militairen bij aankomst in Nederland uit militaire dienst te ontslaan. Tijdens het transport was dit hun niet bekend; er was tot dan toe alleen gesproken over wachtgeld of pensioen. Het volstrekt onverwachte ontslag uit de dienst betekende voor deze beroepsmilitairen een zware schok, omdat zij de status verloren waar zij hun zelfrespect aan ontleenden.

\section{Mislukking van de Indonesisch-Nederlandse Unie}

De Nederlandse weigering van eind december 1950 om West-Nieuw-Guinea over te dragen kwam in Indonesië hard aan. In de loop van het jaar had de Indonesische verstandhouding met Nederland al enige schade opgelopen door de APRA-aanslag op Bandung, de muiterij in Makassar en de opstand op Ambon. Die schade was vooral veroorzaakt door de sympathie voor deze affaires bij een deel van het Nederlandse publiek, maar daar stond telkens tegenover dat de Nederlandse regering zich er zorgvuldig van gedistantieerd had. $\mathrm{Nu}$ was het echter deze regering zelf die Nieuw-Guinea vasthield ondanks het verstrijken van de op de Rondetafelconferentie overeengekomen termijn. In Indonesië werd dit ervaren als een flagrante schending van het gegeven woord; het vertrouwen in Nederland was diep geschokt.

Begin januari 1951 bleek het hele Indonesische parlement geporteerd te zijn voor opheffing van de Indonesisch-Nederlandse Unie en wijziging van de andere RTC-akkoorden. Algemeen beschouwden Indonesische politici die Unie als een constructie die een restant van de koloniale verhouding belichaamde, waardoor er nog steeds geen volledige gelijkheid en gelijkwaardigheid tussen Indonesië en Nederland bestond.

Deze Indonesische visie strookte met wat aan Nederlandse kant oorspronkelijk met de Unie beoogd was. Die constructie dankte haar ontstaan aan de 'commissie-generaal', de in september 1946 door de Nederlandse regering naar Indonesië gezonden delegatie onder oud-premier Schermerhorn die moest proberen een akkoord met de Republiek te sluiten (zie pp. 471-3 en 482-4). Het onderhandelingsmandaat van deze delegatie had geen ruimte gelaten voor een oplossing waarbij Indonesië geen deel meer zou uitmaken 
van het Koninkrijk der Nederlanden. Daarentegen wilde de Republiek voor de toekomstige verhouding tussen Indonesië en Nederland niet verder gaan dan een volkenrechtelijk bondgenootschap tussen twee onafhankelijke staten. Op voorstel van Van Mook had de commissie-generaal toen (zonder overleg met de regering in Den Haag) aan de Republiek een constructie voorgesteld tussen die beide posities in: het toekomstige Indonesië zou zelf geen deel van het Koninkrijk uitmaken, maar zou wel met dit Koninkrijk een bijzondere band aangaan in de vorm van een Unie met aan het hoofd de Nederlandse koningin. Vooral tegen dit laatste had de Republikeinse delegatie groot bezwaar, maar tijdens de besprekingen stond de Republiek onder zware druk omdat in deze zelfde periode schip na schip met Nederlandse militairen in Indonesië aankwam. Nadat de commissie-generaal verklaard had de besprekingen te zullen beëindigen als haar voorstel over de Unie niet aanvaard werd, zette de Republikeinse delegatie zich over haar bezwaren heen. Daarop kwam in november 1946 het akkoord van Linggadjati tot stand. Hoewel de commissiegeneraal de grenzen van haar onderhandelingsmandaat overschreden had, schaarde de Nederlandse regering zich achter dit akkoord.

Tijdens de onderhandelingen had Schermerhorn verklaard dat de Unie alleen als een samenwerkingsverband bedoeld was en geen 'superstaat' zou worden. Maar toen het er om ging in Nederland politieke steun voor het akkoord van Linggadjati te verkrijgen, stelde de Nederlandse regering de daarin voorziene Unie voor als een soort voortzetting van het Koninkrijk in andere vorm. Zij noemde de Unie een 'staatsverband' en ging er onder meer van uit dat er binnen de Unie eenheid van buitenlands beleid zou bestaan en dat de defensie van Indonesië onder de verantwoordelijkheid van de Unie zou vallen. In de loop van 1947 en 1948 pleitten invloedrijke Nederlandse politici voor de vorming van een 'zware' Unie met belangrijke eigen organen en bevoegdheden. Op de Rondetafelconferentie van 1949 verzetten de Indonesische delegaties zich echter krachtig tegen voorstellen in die geest. Het eindresultaat was toen overeenstemming over een 'lichte' Unie die de vrijheid van de twee staten weinig beperkte (zie p. 655). Wel bevatte het Uniestatuut de bepaling dat aan het hoofd van de Unie de koningin van Nederland stond (en bij opvolging haar wettige opvolgers in de Kroon der Nederlanden). Verder hoorden bij dit Statuut afzonderlijke overeenkomsten over financiële en economische kwesties en over samenwerking op het gebied van de buitenlandse betrekkingen, de handelsbetrekkingen, de culturele betrekkingen en de defensie. De overeenkomsten over samenwerking bevatten weinig concrete afspraken, maar omschreven vooral verschillende mogelijkheden daartoe.

De meeste Indonesische politici hadden geen principieel bezwaar tegen samenwerking tussen Indonesië en Nederland, mits die op voet van gelijkheid plaatsvond. Hun bezwaren betroffen vooral de regel dat het Nederlandse staatshoofd aan het hoofd van de Unie stond, want dit leek duidelijk afbreuk 
te doen aan de soevereiniteit en onafhankelijkheid van Indonesië. Niettemin bleek ook de samenwerking in Uniekader niet te beantwoorden aan de Nederlandse verwachtingen.

Op het terrein van de buitenlandse betrekkingen beperkte die samenwerking zich voornamelijk tot de behartiging van Indonesische belangen door Nederlandse ambassades in landen waar Indonesië nog niet over een eigen diplomatieke vertegenwoordiging beschikte. Dit duurde niet lang, want de Indonesische regering droeg zulke belangenbehartiging liever op aan haar eigen ambassades in naburige landen. Verder verzorgde Nederland in de begintijd de opleiding van een aantal Indonesische diplomaten. De in het RTC-akkoord neergelegde afspraak dat Indonesië en Nederland zouden streven naar coördinatie van hun buitenlands beleid bleef daarentegen volledig dode letter. Daarbij valt te bedenken dat de Koude Oorlog tussen het Oostelijk en het Westelijk blok in 1950 zijn koudste fase inging als gevolg van de oorlog in Korea. Nederland koos voor een actieve rol in het Westelijk blok en nam aan de zijde van de Verenigde Staten aan die oorlog deel, terwijl Indonesië koos voor een onafhankelijke rol tussen de blokken.

Ook de in het RTC-akkoord voorziene gemeenschappelijke handelspolitiek van Nederland en Indonesië tegenover derde landen kwam niet van de grond. Wel bleef het leeuwendeel van het Indonesische handelsverkeer met Europa via Nederlandse havens lopen en maakten de RTC-bepalingen het voor Nederlandse ondernemingen mogelijk hun economische activiteiten in Indonesië onder redelijke voorwaarden te hervatten of voort te zetten. Juist hiertegen groeide echter in Indonesië steeds meer verzet. Daarbij werd betoogd dat het kolonialisme in economisch opzicht was blijven bestaan en dat Indonesië pas waarlijk vrij zou worden wanneer aan de Nederlandse dominantie op economisch gebied een eind was gemaakt.

Bijzonder teleurstellend voor Nederland waren de ontwikkelingen op cultureel gebied. Velen hadden juist op dit terrein blijvende banden verwacht, vooral omdat Nederland beschikte over een gedurende eeuwen opgebouwde schat van kennis omtrent land en volk van Indonesië en omdat in Nederland nog steeds een levendige belangstelling voor dit land bestond. In dat kader leek het vanzelfsprekend dat ontwikkelde Indonesiërs nog gedurende generaties vertrouwd zouden blijven met de Nederlandse taal. De feitelijke gang van zaken was echter volstrekt anders. Van de verschillende vormen van samenwerking die in de culturele RTC-overeenkomst waren voorzien kwam niets op gang. Al in 1950 werd in het Indonesische parlement aangedrongen op snelle verwijdering van de Nederlandse culturele elementen uit de samenleving. Ook Soekarno liet weten dat hij niet langer van het 'Nederlandse culturele kolonialisme' gediend was. Binnen enkele jaren verdween de Nederlandse taal op de scholen als voertaal en als leervak. Nederlandse leraren moesten voortaan in het Indonesisch onderwijs geven; de meesten van hen vertrokken al 
spoedig naar Nederland. Aan de universiteiten konden hoogleraren nog enige jaren in het Nederlands college geven, maar de Indonesische regering spande zich niet in voor het aantrekken van nieuwe hoogleraren uit Nederland. Ook bevorderde zij niet langer dat Indonesiërs in Nederland studeerden. In april 1954 gaf zij de ongeveer achttienhonderd nog in Nederland verblijvende Indonesische studenten zelfs opdracht hun studie in een ander land voort te zetten.

Aldus verdween in het onafhankelijke Indonesië binnen korte tijd de kennis van de taal van de vroegere koloniale overheersers. Deze gang van zaken week sterk af van die in andere voormalige koloniën van Europese landen. Men kan deze snelle verdwijning van het Nederlands echter niet los zien van het voorheen door de Nederlanders zelf gevoerde taalbeleid, zowel in negatieve als in positieve zin (zie pp. 140-2). Terwijl de Portugezen, de Spanjaarden, de Britten en de Fransen hun eigen taal in hun koloniën hadden ingevoerd als verkeerstaal voor alle bevolkingsgroepen, hadden de Nederlanders dit in Indonesie juist niet bevorderd. Ook toen in de twintigste eeuw onder de Indonesiërs zelf een groeiende vraag naar voren kwam naar onderricht in de Nederlandse taal, was het koloniale gouvernement daar slechts in beperkte mate aan tegemoetgekomen. Aan de andere kant had dit gouvernement al sinds de negentiende eeuw stelselmatig bijgedragen tot de ontwikkeling van één der inheemse talen, het Maleis, tot algemene verkeerstaal. Dit gemoderniseerde Maleis was in 1928 door de nationale beweging onder de naam Bahasa Indonesia tot nationale taal uitgeroepen (zie p. 207). Dank zij deze voorgeschiedenis had die taal in 1942-1945 de rol van het Nederlands kunnen overnemen toen die door de Japanse bezetters verboden werd. Het daarop in 1945-1949 gevolgde conflict tussen Nederland en de Republiek had ertoe bijgedragen, dat veel nationalisten de Nederlandse taal nu sterk met het kolonialisme associeerden.

Het enige terrein waarop de samenwerking in Unieverband wel van de grond kwam was merkwaardigerwijs dat van de defensie. Aan Indonesische kant bestond grote behoefte aan steun bij de professionalisering van het eigen leger en de opbouw van de eigen marine. Zoals afgesproken op de RTC werd daartoe in 1950 een Nederlandse Militaire Missie opgericht, die uit ongeveer duizend Nederlandse militairen kwam te bestaan. De NMM verstrekte militair-technische adviezen en verzorgde zowel officiersopleidingen als opleidingen op lager niveau. Deze militaire samenwerking breidde zich in 1951 steeds verder uit, maar in nationalistische kringen rees hiertegen verzet. Eind 1952 drong het Indonesische parlement aan op opheffing van de NMM. In april 1953 kwamen de regeringen van Indonesië en Nederland overeen de NMM per 1 januari 1954 te ontbinden. Daarmee kwam een eind aan de laatste vorm van samenwerking in het kader van de Indonesisch-Nederlandse Unie.

In 1947-1949 had de beoogde Unie tussen Indonesië en Nederland een 
onmisbaar argument gevormd om bij een meerderheid van het Nederlandse publiek steun te vinden voor de dekolonisatie van Indonesië. Tegen die achtergrond is het verrassend hoe snel men zich er in Nederland bij neerlegde dat die Unie niet levensvatbaar bleek. Al begin 1951 had de Indonesische regering in overeenstemming met de wens van het Indonesische parlement verklaard, dat zij streefde naar opheffing van de Unie en wijziging van de andere RTCakkoorden. In Nederland bleken vervolgens ook politici die vroeger voor een 'zware' Unie gepleit hadden nu te vinden, dat handhaving van de Unie weinig zin had als Indonesië er zelf geen prijs op stelde. Wel hechtte men belang aan behoud van sommige andere delen van de RTC-akkoorden, vooral die van belang waren voor Nederlandse ondernemingen. In juni 1951 maakte de Nederlandse regering bekend dat zij bereid was met Indonesië besprekingen te voeren over herziening van de betrekkingen. Een probleem was dat de Indonesische regering dit onderwerp alleen samen met de kwestie-NieuwGuinea wilde bespreken, wat de Nederlandse regering afwees. Niettemin vond er sindsdien herhaaldelijk Indonesisch-Nederlands overleg plaats over vervanging van de Unie, maar telkens deden zich incidenten voor die leidden tot afbreken van het overleg.

In 1954 leek een nieuwe overlegronde tot resultaat te leiden. De Indonesische regering wilde toen zo snel mogelijk van de Unie af en was bereid daarbij Nederland op financieel en economisch gebied tegemoet te komen. Op 10 augustus 1954 ondertekenden de beide regeringen een protocol dat voorzag in opheffing van de Unie onder handhaving van de voor Nederland belangrijkste financiële en economische bepalingen van het RTC-akkoord. Dit laatste leidde echter in Indonesië tot een storm van protest. Men verweet de regering dat zij een knieval voor het Nederlandse kolonialisme gemaakt had. Het bleek onmogelijk parlementaire goedkeuring voor het protocol te verkrijgen, zodat de in feite al overleden Unie op papier nog bleef voortbestaan.

$\mathrm{Na}$ een regeringswisseling in Indonesië begonnen eind 1955 in Genève nieuwe besprekingen met Nederland over opheffing van de Unie. Ondanks de weerstanden die het protocol van 1954 had opgeroepen was de nieuwe Indonesische regering tot vrijwel hetzelfde bereid, met uitzondering van een daarbij behorende internationale arbitrageregeling voor geschillen over de financieel-economische bepalingen. De Nederlandse regering wilde de beslechting van zulke geschillen echter niet uitsluitend overlaten aan de Indonesische rechterlijke macht, die juist in die tijd een slechte reputatie verworven had (zie pp. 726-9). Nadat de onderhandelingen op dit punt waren vastgelopen, besloot de Indonesische regering in februari 1956 de Unie en de RTC-akkoorden eenzijdig op te zeggen. Het formele einde kwam op 12 mei, nadat de eenzijdige opzegging ook door het Indonesische parlement goedgekeurd was. 
De eerste jaren parlementaire democratie in Indonesië

Volgens de voorlopige grondwet van augustus 1950 zouden de parlementsleden van de nieuwe Republiek Indonesië te zijner tijd in algemene verkiezingen gekozen worden, maar zou in afwachting daarvan het parlement worden samengesteld uit de leden van de beide kamers van het RVI-parlement plus de leden van het Werkcomité van het KNIP en de leden van de Hoge Adviesraad van de Jogjase Republiek. Het aldus samengestelde parlement telde in totaal 232 leden; zij behoorden tot zeventien politieke partijen. Hoewel deze leden niet gekozen maar benoemd waren, ging men er toch van uit (op grond van een bij de voorbereiding van de grondwet gemaakte afspraak) dat de regering afhankelijk was van steun door een meerderheid in dit parlement. Eenvoudig was dat niet. Evenals in Nederland beschikte geen enkele partij zelf over een parlementaire meerderheid; ieder kabinet had daarom steun van twee of meer partijen nodig en daartoe waren verschillende combinaties mogelijk. Een kabinetscrisis leidde dan ook meestal tot langdurige onderhandelingen over een alternatieve combinatie. Herhaaldelijk bleef een regering die niet meer over een parlementaire meerderheid beschikte toch nog enige maanden in functie voordat ze door een nieuwe ministersploeg werd afgelost. Overigens machtigde de grondwet de regering om op eigen gezag noodwetten uit te vaardigen die van kracht bleven zolang ze niet door het parlement werden ingetrokken.

Anders dan in Nederland was het destijds onbekend in hoever de partijverdeling binnen het parlement overeenkwam met de werkelijke aanhang van de verschillende partijen onder de bevolking. De grootste fractie in het parlement was die van de islamitische Masjumi; ze telde 49 leden. De tweede fractie was die van de nationalistische PNI (vaak als 'Soekarno's eigen partij' beschouwd) met 36 leden. De fractie van de PSI, de door Sjahrir geleide socialistische partij, telde 17 leden. De communistische PKI had een fractie van 13 leden. (Het kan verbazing wekken dat de PKI zitting in het parlement had terwijl de communisten twee jaar eerder onder leiding van Moeso tegen de Republikeinse regering in opstand waren gekomen. Die regering had toen echter wel de opstand neergeslagen, maar de partij zelf niet verboden.) Enige andere in het parlement vertegenwoordigde partijen die al vroeger een rol gespeeld hadden waren de katholieke partij met 9 leden, de protestants-christelijke partij met 5 leden en de door wijlen Tan Malaka gestichte Partai Murba met 4 leden in het parlement. Overigens telde het parlement ook 26 leden die geen lid van een politieke partij waren. Voorzitter van het parlement was het PNI-lid Sartono, die ook het VSI-parlement gepresideerd had. Hij was een veteraan van de nationale beweging, had in de jaren twintig samen met Hatta in het bestuur van de Perhimpoenan Indonesia gezeten en was in 1930 als verdediger opgetreden in het proces tegen Soekarno.

Naast de indeling van Indonesische politici naar de partijen waartoe zij 
behoorden kan men ook een ruwe tweedeling hanteren naar hun persoonlijke opstelling tegenover het politieke werk. Aan de ene kant waren er de zakelijk ingestelde 'bestuurders' die zich vooral richtten op het oplossen van actuele problemen, aan de andere kant waren er de meer populistisch en ideologisch ingestelde 'volksleiders' die hun aanhangers geestdriftig wilden maken voor een toekomstvisioen. De eersten waren geneigd tot geleidelijkheid en overleg; de tweede tot radicale stappen en confrontatie. Deze tweedeling correspondeert min of meer met de tegenstelling tussen de voorstanders van 'diplomatie' en die van 'strijd' in de jaren 1946-1949. De PSI was een typische bestuurderspartij, met veel invloed in de hogere kringen van het bestuursapparaat en de strijdkrachten, maar weinig aanhang onder het grote publiek. De PKI was een ideologische partij die vooral invloed probeerde te krijgen via de vakbeweging. Daarentegen speelden in sommige andere partijen, zoals de Masjumi en de PNI, zowel 'bestuurders' als 'volksleiders' een belangrijke rol. De Masjumi was overigens de enige grote partij die ook buiten de steden en buiten Java veel aanhang had. De nationalistische PNI had geen duidelijke eigen doelstelling meer, nu de Indonesische onafhankelijkheid bereikt en de federale staatsstructuur opgeheven was.

Begin september 1950 trad het eerste kabinet van de nieuwe eenheidsstaat aan. Het werd geleid door Mohammad Natsir, die behoorde tot de bestuurlijk ingestelde jongere garde van de Masjumi, evenals Mohammad Rum en Sjafruddin Prawiranegara, die de ministersposten van buitenlandse zaken en financiën bezetten. Het meest opvallende aan dit kabinet was dat het geen enkele minister uit de PNI bevatte. Daarentegen telde het wel twee ministers uit Sjahrir's PSI en bovendien verscheidene partijloze ministers die daar politiek dicht bij stonden, zoals Hamengku Buwono IX (de sultan van Jogja), die vice-premier werd, en Assaat, die Anak Agung opvolgde als minister van binnenlandse zaken. Het kabinet had een goede verstandhouding met de leiding van de strijdkrachten, maar beschikte nauwelijks over een basis in het parlement. Het nam verschillende maatregelen voor verbetering van de economie en rationalisering van de strijdkrachten en probeerde in december Nederland met grote concessies te bewegen tot overdracht van Nieuw-Guinea. De mislukking van deze poging droeg bij tot verdere verzwakking van zijn binnenlands-politieke positie.

In maart 1951 diende het kabinet-Natsir zijn ontslag in, nadat het met een meerderheid van het parlement in conflict was geraakt over een regeling voor plaatselijke en regionale verkiezingen die in het voordeel van de Masjumi bleek te zijn. Eind april trad een nieuw kabinet aan met als kern zowel leden van de PNI als van de Masjumi, naast leden van enige kleinere partijen. Premier was Sukiman Wirjosandjojo, een oudere Masjumileider die al in 1927 als voorman van de Sarekat Islam met Soekarno samengewerkt had. Het kabinet-Sukiman had een stevige parlementaire basis maar geen goede verstandhouding met 
de legerleiding. Een merkwaardige bijzonderheid was dat twee van de nieuwe ministers in 1946-1948 in de Republiek gevangen hadden gezeten wegens hun rol in een mislukte staatsgreep tegen de regering-Sjahrir (zie pp. 461-2, 572 en 595). Dit waren de minister van buitenlandse zaken Achmad Subardjo en de minister van justitie Muhammad Yamin. Overigens was Subardjo ook in 1945 al minister van buitenlandse zaken geweest in de eerste regering van de Republiek.

Het kabinet-Sukiman was minder bestuurlijk ingesteld dan zijn voorganger. Zowel de premier als sommige andere ministers namen belangrijke initiatieven zonder overleg met hun collega's. Zo liet Yamin in juni 1951 bijna duizend personen vrij die door het leger gearresteerd waren wegens (al of niet vermeende) subversieve activiteiten. Eén van hen was de in maart 1950 gevangen genomen Chaerul Saleh, die tot zijn politieke vrienden behoorde. De legerleiding nam bijna alle vrijgelatenen, onder wie Saleh, opnieuw gevangen en Yamin trad af.

In augustus 1951 liet Sukiman onverwacht op Java en Sumatra ongeveer vijftienduizend personen arresteren die volgens hem de staatsveiligheid bedreigden, voornamelijk communisten en Chinezen. (Sinds het vasteland van China in 1949 als 'Chinese Volksrepubliek' deel van het communistische blok geworden was, werden ook Chinezen in Indonesië ervan verdacht daar diensten aan te bewijzen.) Ook deze golf van arrestaties gebeurde zonder overleg met de legerleiding. Op buitenlands-politiek gebied sloeg Sukiman samen met Subardjo een pro-Amerikaanse koers in. Beiden stonden zij in nauw contact met de Amerikaanse ambassadeur die toen niemand minder was dan Merle Cochran, de man die zich in 1948-1949 als lid van de VN-commissie voor Indonesië bijzonder had ingespannen voor een vergelijk tussen Nederland en de Republiek. Subardjo ondertekende het door de Amerikaanse regering opgestelde vredesverdrag met Japan, dat door China en de Sovjet-Unie afgewezen werd. In januari 1952 sloot hij met Cochran een akkoord in het kader van de Amerikaanse Mutual Security Act, waardoor Indonesië van de Verenigde Staten zowel economische als militaire hulp zou kunnen ontvangen. Toen dit bekend werd rees hier echter zoveel verzet tegen dat het kabinetSukiman zich in februari gedwongen zag af te treden. In Indonesië bleek een brede voorkeur te bestaan voor een buitenlands beleid van onafhankelijkheid tussen de grote blokken.

Begin april 1952 trad een nieuw kabinet aan onder Wilopo, een vertegenwoordiger van de meer bestuurlijk ingestelde jongere garde van de PNI. Dit kabinet leek in zover op zijn voorganger dat hier wederom zowel de PNI als de Masjumi aan deelnamen, maar het was in politieke opstelling meer verwant aan het kabinet-Natsir. Zo keerden Hamengku Buwono en Mohammad Rum in de regering terug, de eerste als minister van defensie, de tweede als minister van binnenlandse zaken, terwijl het kabinet ook twee leden uit Sjahrir's PSI 
telde. Deze regering ontsloeg overigens Chaerul Saleh opnieuw uit gevangenschap en stuurde hem voor een langdurige studiereis naar Europa.

Het kabinet-Wilopo is ruim een jaar in functie gebleven. In die periode deden zich belangrijke veranderingen voor in het binnenlands-politieke landschap van Indonesië. Eén daarvan was een scheuring in de Masjumi. Deze partij had haar basis voornamelijk in twee nog uit de koloniale tijd stammende islamitische massa-organisaties, de modernistische Muhammadiah en de traditionalistische Nahdatul Ulama. De leider van laatstgenoemde organisatie, Wachid Hasjim, was minister van godsdienstzaken geweest in de kabinetten van Hatta, Natsir en Sukiman, maar verder bekleedden leden van zijn organisatie geen belangrijke functies in het Indonesische staatsbestel. Midden 1952 bracht een conflict tussen de beide massa-organisaties de Nahdatul Ulama ertoe uit de Masjumi te treden en een eigen politiek verbond op te richten onder leiding van Wachid Hasjim.

De andere verandering was de wederopstanding van de PKI als belangrijke speler op het politieke toneel. Sinds de Madiun-opstand van 1948 had zij het stigma gedragen van verraad aan de nationale zaak; bovendien had zij in die opstand een deel van haar leiders verloren. In 1951 werd zij verder verzwakt door de anticommunistische acties van premier Sukiman. Maar in datzelfde jaar kreeg zij een nieuwe leider, D.N. Aidit, die haar tot een ingrijpende koerswijziging bracht. Voorheen had de PKI de politiek in klassentermen geïnterpreteerd; zij beschouwde het Indonesisch nationalisme toen als een 'burgerlijke' ideologie en keerde zich tegen Hatta en Soekarno als 'burgerlijke' politici en tegen de PNI als 'burgerlijke' partij. Onder Aidit verdween de marxistische analyse naar de achtergrond. De PKI ging nu de nationalistische toer op en zocht toenadering tot de PNI. Terwijl zij Soekarno vroeger gehekeld had wegens zijn collaboratie met Japan, vereerde zij hem nu als de grote leider van de natie. Ook werd de PKI oppermachtig in de grootste vakcentrale, de SOBSI.

Het kabinet-Wilopo probeerde de belangrijkste interne problemen aan te pakken waar Indonesië destijds mee te kampen had. Naast de zwakke financiële en economische situatie was dit ook de grote omvang van de strijdkrachten: als erfenis van de vrijheidsstrijd waren die nog tweehonderdduizend man sterk. Generaal-majoor Simatupang, staf-chef van de strijdkrachten, en kolonel Nasution, staf-chef van het landleger, wilden hiervan tachtigduizend man demobiliseren als stap naar de vorming van een kleinere maar meer professionele strijdmacht. Naar hun mening had Indonesië nu niet een volksleger maar een beroepsleger nodig. Deze reorganisatie had de instemming van minister Hamengku Buwono, maar stuitte op hevig verzet binnen de strijdkrachten zelf, zowel onder hoge officieren die hun militaire loopbaan onder Japanse leiding begonnen waren als onder soldaten die vreesden het leger te moeten verlaten. Dit verzet kreeg steun van president Soekarno, van de radicale vleu- 
gel van de PNI en verder onder meer van de PKI en de Nahdatul Ulama.

Er ontstond een situatie die enigzins leek op die van september 1948, toen een controverse over sanering van het Republikeinse leger tot conflicten leidde die uitmondden in de Madiunopstand. Nu werd de kwestie van legersanering maandenlang besproken in het parlement, waarbij zowel het ministerie van defensie als de legerleiding een stortvloed van kritiek te verduren kreeg. Nasution ergerde zich hieraan; hij vond de meeste parlementariërs incompetent en onverantwoordelijk. Een aantal met hem gelijkgezinde officieren maakten plannen voor uitschakeling van het parlement. Op 16 oktober nam dit parlement een motie aan die zinspeelde op vervanging van de leiding van de strijdkrachten en van het ministerie van defensie. De volgende ochtend brachten legervoertuigen duizenden demonstranten naar het centrum van Djakarta, waar zij zich voor het presidentspaleis verzamelden en ontbinding van het parlement eisten. Staande op het bordes van het paleis hield Soekarno een toespraak waarin hij uitlegde niet aan deze eis te kunnen voldoen omdat dit dictatuur zou betekenen. De menigte juichte hem geestdriftig toe en ging uiteen. Intussen waren ook tanks en pantserwagens verschenen, met hun geschut dreigend op het paleis gericht. Soekarno kreeg bezoek van een deputatie van officieren die eveneens ontbinding van het parlement verlangde, maar ook hier gaf hij niet aan toe. Uiteindelijk staakten de rebellerende officieren hun acties.

De mislukte machtsgreep van 17 oktober 1952 leidde tot langdurige tweespalt binnen de strijdkrachten tussen 'pro-17-oktober'-officieren en 'anti-17oktober'-officieren. De regering schorste Nasution als stafchef van het leger. Er kwam geen radicale legerhervorming. Het parlement drong aan op opheffing van de Nederlandse Militaire Missie. Begin 1953 trad Hamengku Buwono af als minister van defensie. Binnen de PNI was de positie van premier Wilopo ernstig verzwakt, maar het duurde nog tot juni 1953 voordat ook hij zich gedwongen zag af te treden.

De afwisseling tussen bestuurlijk ingestelde en populistisch ingestelde kabinetten zette zich nog enige jaren voort. Van juli 1953 tot juli 1955 stond de regering onder leiding van Ali Sastroamidjojo, die tot de oude garde van de PNI behoorde en in 1928 samen met Hatta in Den Haag terechtgestaan had. In dit kabinet zaten voor het eerst geen ministers uit de Masjumi; daarentegen wel drie ministers uit de Nahdatul Ulama. Naast Ali Sastroamidjojo bevatte het kabinet nog een andere veteraan uit de nationale beweging, namelijk Iwa Kusuma Sumantri, die in de jaren dertig samen met Hatta en Sjahrir op Banda geïnterneerd had gezeten en in 1945 deel had uitgemaakt van het eerste kabinet van de Republiek; hij werd nu minister van defensie. Ook keerde Muhammad Yamin in de regering terug, nu als minister van onderwijs. De regering-Ali voerde een uitgesproken populistisch en nationalistisch beleid, ook omdat de PNI de nieuwe radicaal-nationale koers van de PKI probeerde te overtroeven. $\mathrm{Zij}$ zette generaal Simatupang aan de kant door diens functie 
van stafchef van de strijdkrachten af te schaffen. Zij gaf de Indonesische studenten in Nederland opdracht hun studie elders voort te zetten. Tijdens haar regeerperiode begonnen opzienbarende processen tegen enige Nederlanders op beschuldiging van grootscheepse subversieve activiteiten. Verder wilde de regering-Ali zo snel mogelijk een eind maken aan de Indonesisch-Nederlandse Unie onder de Nederlandse koningin. Zij sloot daartoe in augustus 1954 een akkoord met de Nederlandse regering, maar, zoals al in de vorige paragraaf vermeld, werd dit door het thuisfront verworpen.

Ali Sastroamidjojo's grootste succes was de organisatie in april 1955 van een conferentie van Aziatische en Afrikaanse staten in Bandung, waar Soekarno als belangrijk wereldleider kon optreden naast onder meer de Indiase premier Nehru en de Egyptische president Nasser. Intussen had binnen de krijgsmacht een verzoening plaatsgevonden tussen de 'pro-17-oktober'-officieren en de 'anti-17-oktober'-officieren. Beide groepen verzetten zich tegen een reeks ingrepen van minister Iwa in de defensieorganisatie. Dit verzet leidde in juli 1955 tot de val van Ali's kabinet.

De volgende regering werd weer geleid door een vertegenwoordiger van de jonge garde van de Masjumi, Burhanuddin Harahap, en was opnieuw vooral een kabinet van 'bestuurders'. In tegenstelling tot het door de PNI gedomineerde kabinet-Ali bevatte dit nieuwe kabinet geen enkele minister uit de PNI. Anak Agung, die in 1950 minister van binnenlandse zaken geweest was in de regering van de RVI, keerde nu terug als minister van buitenlandse zaken. Het kabinet-Harahap duurde van augustus 1955 tot maart 1956. Tijdens die kabinetsperiode vonden in september 1955 eindelijk de lang verwachte parlementsverkiezingen plaats; het kabinet functioneerde daarom als een soort interim-regering in afwachting van de bijeenkomst van het nieuwe parlement. Het stelde Nasution, die intussen weer op goede voet met Soekarno was komen te staan, opnieuw aan als stafchef van het leger, nu met de rang van generaal-majoor. Verder vonden onder het kabinet-Harahap voor het laatst besprekingen met Nederland plaats over ontbinding van de Indonesische-Nederlandse Unie en wijziging van de RTC-akkoorden. Zoals in de vorige paragraaf vermeld mislukten die onderhandelingen, waarna het kabinet in februari 1956 besloot de Unie en de RTC-akkoorden eenzijdig op te zeggen. Het kabinet-Harahap bleef in functie totdat in maart 1956 het gekozen parlement bijeenkwam en een tweede kabinet-Ali aantrad.

\section{Verscherping van het geschil over Nieuw-Guinea}

In maart 1951 had de Nederlandse regering de kwestie van de toekomst van Nieuw-Guinea voor onbepaalde tijd 'in de ijskast' gezet. Daarentegen was die kwestie voor Indonesië zelf een steeds dringender prestigezaak geworden. 
Dat Nieuw-Guinea nog niet met Indonesië herenigd was werd door Soekarno voorgesteld als het grootste probleem van zijn land. De heftigheid waarmee hij en zijn radicaal-nationalistische aanhang overdracht van dat gebied eisten werkte echter in Nederland averechts. Zo hadden de dreigende verklaringen van Muhammad Yamin en Bung Tomo in oktober-november 1950 het voor de Nederlandse regering alleen maar moeilijker gemaakt om Indonesië op dit punt tegemoet te komen, want niemand wil graag de indruk wekken dat hij voor dreigementen zwicht.

Overigens was de Nederlandse opstelling in deze kwestie niet minder emotioneel dan de Indonesische. Het leek wel alsof alle frustratie in Nederland over het verlies van 'Indië' nu een uitlaat zocht in het vasthouden van NieuwGuinea. Wat de juridische kant van het geschil betreft ging men er zonder meer van uit dat de soevereiniteit over het gebied bij Nederland was blijven berusten. Invloedrijke Nederlandse politici zoals Romme legden zich hardnekkig vast op het standpunt, dat Nederland het gebied moest blijven besturen zolang de bevolking zich niet zelf over haar toekomst kon uitspreken. Als Nederland moest kiezen tussen Nieuw-Guinea en het behoud van de Indonesisch-Nederlandse Unie, dan zou de keuze volgens die politici op Nieuw-Guinea moeten vallen.

Nadat het kabinet-Natsir in december 1950 vergeefs geprobeerd had Nederland langs de weg van overleg tot overdracht van Nieuw-Guinea te bewegen, ondernam het kabinet-Sukiman eind 1951 een nieuwe poging. Het zond een delegatie naar Nederland onder leiding van oud-minister Supomo, met machtiging om zowel over opheffing van de Indonesisch-Nederlandse Unie als over Nieuw-Guinea besprekingen te voeren. De Indonesische delegatie, waar ook Yamin deel van uitmaakte, nam daarbij het standpunt in dat de soevereiniteit over Nieuw-Guinea al bij Indonesië berustte. Een Nederlands voorstel om het juridische geschil over de status van Nieuw-Guinea aan een onafhankelijke rechterlijke instantie voor te leggen werd door Supomo afgewezen met het argument dat het niet om een juridisch maar om een politiek geschil ging. In januari 1952 stelde hij voor dat men in afwachting van de in juni in Nederland te houden parlementsverkiezingen alvast een gemengd Indonesisch-Nederlands bestuur zou instellen onder een Indonesische gouverneur, waarna de beide regeringen dan na de verkiezingen onderhandelingen zouden voeren over de definitieve bestuursoverdracht. Dit voorstel was volstrekt kansloos. Niet lang daarna moest Supomo de besprekingen afbreken wegens de val van het kabinet-Sukiman.

In het voorjaar van 1952 deed Soekarno zelf een compromisvoorstel in een gesprek met Paul Rijkens, president-directeur van Unilever (één van de grootste Nederlandse concerns). Ook dit voorstel voorzag in gezamenlijk beheer van het gebied, waarbij Nederland de positie van een 'senior partner' zou krijgen met grote bestuursbevoegdheden en speciale voordelen op economisch 
terrein. Drees wilde dit voorstel echter niet in behandeling te nemen wegens de naderende parlementsverkiezingen.

Na de Nederlandse verkiezingen van juni 1952 trad in september een nieuw kabinet-Drees aan, nu met ministers uit de PvdA, de KVP, de CHU en de ARP. De toetreding van de ARP betekende dat een partij die het Nederlandse Indonesiëbeleid in de afgelopen jaren steeds te toegeeflijk gevonden had nu verantwoordelijkheid voor het regeringsbeleid ging dragen. De uittreding van de VVD betekende onder meer het vertrek van Stikker, die persoonlijk voor overdracht van Nieuw-Guinea aan Indonesië geweest was maar zich had neergelegd bij het standpunt van zijn partij en van het kabinet. Als minister van buitenlandse zaken werd hij in het nieuwe kabinet opgevolgd door twee ministers, van wie de één zich zou bezighouden met Europese zaken en de ander met niet-Europese zaken. Op voorstel van Romme werd deze laatste rol toebedeeld aan J.M.A.H. Luns, een katholieke diplomaat die hem al dikwijls van advies had gediend over internationale kwesties. Luns was een markante figuur die vond dat Nederland zijn invloed aan de andere kant van de aardbol zoveel mogelijk moest behouden; daarom moest Nederland volgens hem een sterke marine handhaven en het westelijk deel van Nieuw-Guinea even lang vasthouden als Australië het oostelijk deel. (In 1956 kwam het departement van buitenlandse zaken weer onder eenhoofdige leiding. Luns bleef tot 1971 minister van buitenlandse zaken en kon dus nog vele jaren zijn stempel op het Nederlandse Indonesiëbeleid drukken.)

Kort na de verkiezingen had Lamping, de Nederlandse Hoge Commissaris in Djakarta, de regering gewaarschuwd dat alle Nederlandse invloed in Indonesië verloren dreigde te gaan als Nederland op het punt van NieuwGuinea onbuigzaam bleef. Soortgelijke waarschuwingen waren in Den Haag geuit door ambtenaren van het departement van buitenlandse zaken die de relatie met Indonesië behandelden. Het mocht niet baten; de Nederlandse opstelling werd steeds harder.

Zo deed zich eind 1952 ook een opmerkelijke verharding voor in de opstelling van de Partij van de Arbeid. Twee invloedrijke leden van de PvdAfractie in de Tweede Kamer die in 1945-1949 vurige pleitbezorgers voor het Indonesische vrijheidsstreven geweest waren, Frans Goedhart en Jacques de Kadt, vonden overdracht van Nieuw-Guinea nu niet langer verantwoord. Hun politieke denken werd destijds overheerst door de Koude Oorlog en zij waren zeer beducht dat Indonesië naar het communistische kamp zou kunnen overgaan. Goedhart had in najaar 1952 op uitnodiging van de Indonesische regering enige maanden door Indonesië gereisd, maar had zich toen bijzonder geërgerd aan Soekarno's monomane retoriek over Nieuw-Guinea onder verwaarlozing van Indonesië's reële problemen.

Soekarno was bij uitstek een volksleider en geen bestuurder. Tot 1950 had hij al zijn politieke inspanningen op één doel gericht: onafhankelijkheid voor 
Indonesië, maar hij had nooit veel belangstelling getoond voor de vraag wat er gebeuren moest wanneer dat doel eenmaal bereikt was. Intussen wekte de nu bereikte onafhankelijkheid onder de Indonesische bevolking niet alleen voldoening maar ook teleurstelling. Velen hadden daarvan louter vooruitgang en voorspoed verwacht, maar het tegendeel was eerder het geval. Vooral op Java was er sprake van een voortschrijdende economische en sociale ontreddering, die onder meer veroorzaakt werd door de naweeën van de Japanse bezetting en het conflict met Nederland en door een nijpend tekort aan geschoolde krachten. Dat Soekarno in zijn toespraken steeds hamerde op het onvoltooid zijn van de Indonesische revolutie zolang Nieuw-Guinea nog in Nederlandse handen bleef, kwam ten dele voort uit zijn verlangen iets van het elan, de opofferingsgezindheid en de saamhorigheid terug te roepen waarmee de vrijheidsstrijd gepaard was gegaan. Dit betekent niet dat hij deze onvoltooidheid het liefst zag voortduren, want hij wenste wel degelijk de rood-witte vlag over Nieuw-Guinea te zien waaien. Door het mobiliseren van nationale volkswoede hoopte hij de druk op Nederland te vergroten. Overigens was hij niet altijd tegen concessies om het Nederland gemakkelijker te maken de soevereiniteitsaanspraak op Nieuw-Guinea te laten varen. Dit was nog in het voorjaar van 1952 in zijn gesprek met Paul Rijkens gebleken.

In Indonesië deed het in april 1952 aangetreden kabinet-Wilopo geen pogingen meer om de kwestie Nieuw-Guinea met Nederland te bespreken. Vervolgens stelde het in juli 1953 gevormde kabinet-Ali Sastroamidjojo zich in deze kwestie aanzienlijk militanter op. Het liet al spoedig weten dat, als Nederland overeenstemming over Nieuw-Guinea bleef uitsluiten, Indonesië voorbereidingen zou treffen om het gebied met andere middelen dan onderhandelingen terug te krijgen. In 1954 stelde deze regering een West-Irian Bureau in dat de bevolking moest doordringen van de noodzaak van terugkeer van Nieuw-Guinea in het Indonesische staatsverband. Toch opende deze zelfde regering ook besprekingen met Nederland, niet omdat zij verwachtte daarmee ten aanzien van Nieuw-Guinea een stap verder te komen, maar omdat zij definitief een eind wilde maken aan de Indonesisch-Nederlandse Unie. Inderdaad weigerde Nederland over Nieuw-Guinea te spreken, maar wel ondertekenden de beide regeringen in augustus 1954 een protocol over opheffing van de Unie. Zoals al eerder vermeld werd dit protocol in Indonesië zeer negatief ontvangen zodat het niet in werking kon treden.

Bij haar weigering om over Nieuw-Guinea te spreken kon de Nederlandse regering in 1954 rekenen op massieve steun in het parlement. Met uitzondering van de communistische partij waren alle partijen het erover eens, dat de soevereiniteit over het gebied bij Nederland berustte en moest blijven berusten totdat de bevolking ervan in staat zou zijn zelf over haar staatkundig lot te beslissen, dat er geen sprake kon zijn van nieuwe onderhandelingen met Indonesië over de toekomstige status van het gebied en dat Nederland geen 
enkele vorm van gemengd bestuur of gedeelde verantwoordelijkheid voor het gebied zou mogen aanvaarden.

De regering-Ali besloot nu een andere weg in te slaan. Op 17 augustus 1954 kondigde Soekarno aan dat Indonesië zich over deze kwestie tot de Verenigde Naties zou wenden. In september zette de Algemene Vergadering der Verenigde Naties (AVVN) de kwestie inderdaad op de agenda van haar najaarszitting en ook in enige latere zittingen hield zij zich met dit onderwerp bezig. De pogingen van Indonesië om langs deze weg Nederland onder druk te zetten werden echter een uitermate frustrerende exercitie.

Omdat Indonesië de kwestie voorstelde als een probleem dat de vrede in gevaar zou kunnen brengen, kon de AVVN hier alleen met een meerderheid van twee derde besluiten over nemen. De door Indonesië gewenste ontwerpresoluties behaalden echter telkens wel een gewone maar geen twee derde meerderheid. Er bestond destijds in de Verenigde Naties nog niet zo'n overwicht van niet-westers georiënteerde staten als later ontstaan is, vooral na de toetreding van tientallen voormalige Franse en Britse koloniën. Verder kreeg Nederland in zijn verzet tegen die ontwerp-resoluties niet alleen steun van de Europese niet-communistische landen maar ook van veel Latijns-Amerikaanse landen. De Verenigde Staten onthielden zich van stemming.

In 1954 ging de stemming over een ontwerp-resolutie die alleen maar de hoop uitsprak dat de regeringen van Indonesië en Nederland zouden blijven streven naar een oplossing van hun geschil over Nieuw-Guinea en die hun verzocht daarover verslag uit te brengen aan de AVVN. Desondanks verzette Nederland zich hier krachtig tegen. De ontwerp-resolutie kreeg uiteindelijk 34 voorstemmen en 23 tegenstemmen.

In 1955 voelde Indonesië zich gesterkt omdat de Afro-Aziatische conferentie in Bandung in april met algemene stemmen een resolutie aangenomen had die het Nederlandse Nieuw-Guineabeleid verwierp als een vorm van kolonialisme. Niettemin zag de regering-Harahap er eind 1955 van af om weer in de AVVN te laten stemmen over een Nederland onwelgevallige tekst, omdat zij toen zelf nieuw bilateraal overleg met Nederland aanging. De tussen de beide regeringen overeengekomen agenda voor dat overleg betrof in de eerste plaats de beëindiging van de Indonesisch-Nederlandse Unie, maar bevatte ook een agendapunt luidende: 'Bespreking van bepaalde vraagstukken betreffende Nieuw-Guinea, met dien verstande dat ten aanzien van de soevereiniteit iedere partij haar eigen standpunt handhaaft'. Kennelijk was het eerste deel van deze formule voor het Indonesische publiek bestemd en het tweede deel voor het Nederlandse publiek. Het overleg vond in Genève plaats. Daarbij werd de Indonesische delegatie geleid door minister Anak Agung en de Nederlandse delegatie door minister Luns. De bespreking van kwesties met betrekking tot Nieuw-Guinea leidde echter tot niets, terwijl zoals al in vorige paragrafen vermeld ook het overleg over de beëindiging van de Unie op een mislukking 
uitliep. Begin 1956 is dit voor Indonesië aanleiding geweest is om de Unie eenzijdig op te zeggen.

In het voorjaar van 1956 maakte het kabinet-Harahap plaats voor het tweede kabinet onder Ali Sastroamidjojo. In het najaar kwam in de AVVN een nieuwe ontwerp-resolutie over Nieuw-Guinea in stemming. Naar het voorbeeld van de VN-bemoeienis uit 1947-1948 met het conflict tussen Nederland en de Republiek voorzag dit ontwerp in de benoeming van een VN-Commissie van Goede Diensten die een rechtvaardige en vreedzame oplossing van de NieuwGuinea-kwestie zou moeten bevorderen. Deze resolutie kreeg 40 voorstemmen en 25 tegenstemmen en haalde dus wederom niet de vereiste twee derde meerderheid. In najaar 1957 legde de Indonesische regering de kwestie voor de derde maal aan de AVVN voor, waarbij zij uitdrukkelijk liet weten dat dit de laatste maal zou zijn.

De frustratie in Indonesië over de mislukking van de initiatieven in de Verenigde Naties was des te groter, omdat de bevolking in deze zelfde periode bewerkt werd met een steeds heftiger propagandacampagne tegen de Nederlandse aanwezigheid in Nieuw-Guinea. Hierbij werd de regeringAli krachtig gesteund door de PNI, de PKI en ook de Nahdatul Ulama. Er vonden talloze anti-Nederlandse demonstraties plaats en er werd dikwijls gevraagd om stappen tegen de Nederlandse belangen in Indonesië. Ook trokken Indonesische strijders soms Nieuw-Guinea zelf binnen. In oktober 1954 ontvoerde een Indonesische infiltratiegroep onder Papoealeiding daar een Nederlandse politieagent. De internationale publiciteit hierover was de Indonesische regering welkom, opdat men ook binnen de Verenigde Naties zou gaan beseffen dat het conflict over Nieuw-Guinea zich tot een gevaarlijke situatie ontwikkelde. De Nederlandse agent bleef een jaar lang in Indonesische gevangenschap. Daarna liet de regering-Harahap hem vrij omdat zij het bilaterale overleg met Nederland wilde hervatten. Na de mislukking van dat overleg en het aantreden van de tweede regering-Ali Sastroamidjojo nam de anti-Nederlandse campagne nog in hevigheid toe.

\section{Anti-Nederlandse processen in Djakarta}

Hoewel er in 1949 een eind gekomen was aan het grote militaire conflict tussen de Republiek Indonesië en Nederland, betekende dit niet dat er daarna binnen Indonesië geen gewapende strijd meer gevoerd werd. Al ten tijde van de Nederlandse soevereiniteitsoverdracht bestonden hier verschillende Indonesische strijdgroepen die niet bereid waren zich aan het gezag van Soekarno en Hatta te onderwerpen. Verreweg de belangrijkste daarvan was de Darul Islam die sommige delen van West-Java beheerste en wier leider, Kartosuwirjo, een Islamitische Indonesische Staat uitgeroepen had. Midden 
1950 ontstond er ook een breuk tussen de centrale regering en een grote guerrilla-organisatie in Zuid-Celebes die bezwaar had tegen de voorwaarden waaronder zij tot het leger kon toetreden. Deze opstandige beweging onder leiding van Kahar Muzakkar, een streng-orthodoxe moslim, sloot zich in 1952 bij de Darul Islam aan. In 1953 vond in Indonesië een verdere scheuring plaats in de vorm van een opstand in Atjeh onder leiding van Daud Beureuh, een Masjumi-politicus die voor 1950 de belangrijkste Republikeinse bestuurder in Atjeh geweest was. Verder waren de Indonesische strijdkrachten, ondanks de herovering van Ambon eind 1950, er nooit in geslaagd volledig een eind te maken de opstandige beweging die zich Republiek der Zuid-Molukken (RMS) noemde; onder meer op het eiland Ceram voerden RMS-aanhangers nog steeds een guerrilla tegen de centrale regering.

Voor een groot deel van het Indonesische publiek was het onbegrijpelijk dat de eigen strijdkrachten er niet in slaagden deze opstandige bewegingen uit te schakelen. De veronderstelling lag daarom voor de hand dat die bewegingen buitenlandse steun kregen. Daarbij richtten de verdenkingen zich in de eerste plaats op Nederland. De Nederlandse avonturier Westerling had immers begin 1950 zelf beweerd over een eigen leger te beschikken, de APRA. Daarna was zijn aanslag op Bandung weliswaar mislukt en was hij zelf uit Indonesië gevlucht, maar men kon zich afvragen waar het gros van zijn leger gebleven was. Bovendien genoot hij in Nederland alle vrijheid om tegen de Indonesische eenheidsstaat te ageren en werd in hetzelfde Nederland openlijk geld ingezameld voor steun aan de RMS. Tegen die achtergrond deden al jarenlang geruchten de ronde dat Nederlandse oud-officieren actief meestreden met de Darul Islam.

In 1953 zaten nog twaalf Nederlanders in hechtenis die in 1950 gearresteerd waren op verdenking van medeplichtigheid aan de activiteiten van Westerling. In augustus en november werden zij nu eindelijk vrijgelaten, maar dit leidde tot felle kritiek op de regering-Ali Sastroamidjojo. Zowel van militaire als van links-politieke kant stelde men dat deze verdachten terecht hadden moeten staan.

Na deze omstreden vrijlatingen volgde tot veler verrassing een nieuwe arrestatiegolf, niet door de gewone politie of door het leger maar door een onder de premier staande veiligheidsdienst, de Dinas Pengawas Keselamatan Negara (DPKN, Dienst voor Toezicht op het Welzijn van de Staat). Deze veiligheidsdienst nam op Java tussen half december 1953 en eind januari 1954 meer dan dertig Nederlanders gevangen. Al in januari berichtten Indonesische kranten dat een grote ondergrondse organisatie opgerold was, die NederlandsIndische Guerrilla Organisatie (NIGO) zou heten en zou samenwerken met de Darul Islam. Al deze berichten berustten niet op eigen journalistiek onderzoek maar op anonieme mededelingen van hogerhand. De zogenaamde NIGO bestond in werkelijkheid niet en had nooit bestaan. 
Hoewel de DPKN ruim dertig Nederlanders gearresteerd had, richtte zij zich in hoofdzaak op de voorbereiding van processen tegen slechts twee van hen, L. Jungschläger en H. Schmidt. Jungschläger had voor de Tweede Wereldoorlog gewerkt bij het interinsulaire scheepvaartbedrijf KPM. Tijdens de oorlog had hij bij de Nederlandse marine gediend; eind 1944 was hij in Australië bij de Nederlandse inlichtingendienst NEFIS gekomen en van april tot november 1947 was hij daar hoofd van geweest. Daarna was hij gedemobiliseerd en teruggekeerd bij de KPM. Schmidt was een voormalige KNILofficier die de oorlog in Japanse gevangenschap doorgebracht had. Na de opheffing van het KNIL in 1950 had hij eerst bij Garuda Indonesian Airways in Djakarta gewerkt en was hij vervolgens in dienst getreden bij een makelaarskantoor in Bandung.

De DPKN wilde deze twee Nederlandse oud-officieren presenteren als leiders van een grote subversieve organisatie. De overige arrestanten zouden bewijs tegen hen moeten leveren door verklaringen af te leggen die hun door de DPKN werden opgegeven. Om hen tot die verklaringen te dwingen werden veel arrestanten mishandeld, onder meer met afranselingen en met onderdompeling in water. Het lukte enkelen van hen om briefjes uit de gevangenis te smokkelen waarin zij om hulp vroegen. Al in februari bereikten zulke noodkreten het Nederlandse Hoge Commissariaat. Omdat het ministerie van justitie liet weten geen zeggenschap over de DPKN-gevangenen te hebben wendde de Nederlandse Hoge Commissaris zich tot premier Ali zelf, maar die deed de berichten over mishandeling af als verzinsels.

Pas eind juni, toen de regering-Ali onderhandelingen met Nederland opende over ontbinding van de Indonesisch-Nederlandse Unie, kregen medewerkers van het Hoge Commissariaat toestemming om de Nederlandse arrestanten te bezoeken, maar zonder mogelijkheid hen onder vier ogen te spreken. Op 9 september 1954 begon onder grote publieke belangstelling het proces tegen Schmidt. Sommige dagbladen verlangden al bij voorbaat de doodstraf tegen 'deze vijand van het volk'. Volgens de openbare aanklager was Schmidt opgetreden als leider van de NIGO en was dit een organisatie die ten doel had de wettige Indonesische regering omver te werpen; daarbij zou hij onder meer de Darul Islam van wapens en levensmiddelen hebben voorzien en gewapende aanvallen hebben geleid op leger- en politie-eenheden. Het Hoge Commissariaat had er intussen voor gezorgd dat Schmidt verdedigd werd door twee advocaten, de Nederlander H. Bouman en de Indonesische mevrouw Razak. Er volgden nog vele zittingen. Het proces was openbaar en werd ook door Nederlandse journalisten bijgewoond.

In Nederland trok deze rechtzaak uiteraard bijzondere aandacht, die nog toenam toen daar in oktober onthullingen in de pers verschenen over de mishandeling van arrestanten. De Nederlandse regering had zelf nog geen bekendheid aan die mishandelingen gegeven, omdat zij hoopte de 
Indonesische regering onder druk te kunnen zetten door met publiciteit te dreigen.

Tot de door de openbare aanklager in het proces opgevoerde getuigen behoorden, naast Nederlanders die in het begin van het jaar gearresteerd waren, ook verscheidene Indonesiërs. Vooral hun verklaringen waren vaak bijzonder vreemd. Zo zei een getuige dat Kartosuwirjo (de belangrijkste opstandelingenleider van Indonesië) meermalen in Djakarta de Nederlandse Hoge Commissaris persoonlijk had bezocht. Ook zou Kartosuwirjo in de eetzaal van een groot hotel in Djakarta een geheime bespreking met Schmidt hebben gevoerd. Verder zou Schmidt aan de zuidkust van Java zijn gezien terwijl daar een duikboot opdook waaruit drie grote motorboten gelost werden. Overigens noemden de getuigen zoveel dagen waarop ze Schmidt in de bergen van West-Java gezien hadden, dat hij nauwelijks tijd gehad zou hebben om op zijn kantoor in Bandung te werken. De meeste Indonesische kranten gaven de aantijgingen tegen de zogenaamde NIGO uitgebreid weer, zonder aandacht voor deze ongerijmdheden.

Schmidt en zijn advocaten toonden de ongeloofwaardigheid van veel zulke getuigenissen aan. Kennelijk was de rechter zelf ook niet van die getuigenissen onder de indruk, naar bleek uit zijn kritische vragen aan de getuigen. In november werd het proces echter plotseling geschorst; kort daarna trok de rechter zich om gezondheidsredenen terug. Pas in maart 1955 werd het proces hervat, nu onder een andere rechter die zich minder kritisch opstelde dan zijn voorganger.

In februari 1955 begon eindelijk ook het proces tegen Jungschläger, onder nog een andere rechter. Volgens de openbare aanklager was Jungschläger het eigenlijke brein achter de complotten. Hij zou de leiding gehad hebben van verschillende ondergrondse bewegingen, waaronder de APRA en de NIGO, die er op uit waren de regering van Indonesië omver te werpen en het Nederlandse gezag te herstellen.

Ook in het proces-Jungschläger traden Bouman en mevrouw Razak als verdedigers op, maar de aanklager spande zich nu in om hen uit te schakelen door henzelf van strafbare feiten te beschuldigen. Al in februari onderwierp hij Bouman aan een langdurig verhoor; in april werd ook mevrouw Razak beschuldigd en verhoord. Bouman trok zich als verdediger terug; hij kreeg een uitreisverbod maar wist begin mei via Singapore naar Nederland te vluchten. Kort daarop trok ook mevrouw Razak zich uit de verdediging terug. Intussen had de Nederlandse regering een Britse advocaat bereid gevonden om Schmidt en Jungschläger te verdedigen, maar de Indonesische regering weigerde hem toe te laten.

Er kwam nu een nieuwe wending die de belangstelling in Nederland voor de processen bijzonder stimuleerde: Bouman's vrouw, die zelf geen juriste was maar de twee processen nauwkeurig gevolgd had, nam de verdediging van 
Schmidt en Jungschläger over. Zij bleek over een uitstekend geheugen, een helder inzicht en grote persoonlijke moed te beschikken. Verder publiceerde de Nederlandse regering in juni een witboek in verschillende talen over de politieke processen in Indonesië en de daarmee verbonden mishandeling van arrestanten. Overigens kwam het nu ook in die processen zelf voor dat getuigen in de rechtzaal openlijk verklaarden te zijn mishandeld.

In augustus 1955 maakte het kabinet-Ali plaats voor het kabinet-Harahap, maar tot teleurstelling van Nederland bleven de processen zich voortslepen. Bovendien werd de sfeer steeds dreigender. Op de zittingsdagen werd het gerechtsgebouw omringd door demonstranten die riepen om de doodstraf tegen Jungschläger en Schmidt. Soms werd ook mevrouw Bouman bedreigd. In februari 1956 eiste de aanklager de doodstraf tegen Jungschläger. In maart kreeg Jungschläger voor het laatst het woord. De uitspraak zou eind april volgen, maar zover kwam het niet. Op 19 april stierf hij aan een hersenbloeding.

Intussen was Ali Sastroamidjojo eind maart teruggekeerd als ministerpresident. De rechter die het proces tegen Jungschläger voorgezeten had werd minister van justitie in het nieuwe kabinet-Ali. Verder kwam er een eind aan de Indonesisch-Nederlandse Unie, zodat Nederland nu niet meer door een Hoge Commissaris vertegenwoordigd werd. Het proces tegen Schmidt ging nog een half jaar door.

In augustus 1956 eiste de aanklager tegen Schmidt een gevangenisstraf van vijftien jaar. Op 17 september hield deze zijn laatste verdedigingsrede. Heel Djakarta hing vol leuzen die de doodstraf tegen hem verlangden. Mevrouw Bouman werd na de zitting door demonstranten aangevallen; met hulp van Nederlandse journalisten kon zij zich binnen het gerechtsgebouw verbergen en later wegvluchten over een muur. Omdat zij haar leven niet meer zeker was vertrok zij kort daarna naar Nederland. De rechter veroordeelde Schmidt in oktober overeenkomstig de eis tot vijftien jaar gevangenisstraf.

Een deel van de in 1954 gearresteerde Nederlanders was intussen vrijgelaten. In de loop van 1957 kregen alle nog in voorarrest vastzittende arrestanten hun vrijheid terug. Schmidt zelf bleef gevangen tot maart 1959.

Niets heeft de verhouding tussen Indonesië en Nederland ooit meer kwaad gedaan dan de schijnprocessen tegen Schmidt en Jungschläger. Voor sommige Indonesische gezagsdragers kwamen die processen goed van pas, omdat ze de aandacht afleidden van hun eigen falen in de oplossing van de binnenlandse problemen en in de beëindiging van de opstandige bewegingen. Vooral op Java heerste er onder de bevolking teleurstelling over de economische en sociale achteruitgang sinds het bereiken van de onafhankelijkheid. De berichten over de zogenaamde NIGO brachten daar een bevredigende verklaring voor: die achteruitgang was het gevolg van Nederlandse sabotage. Tussen de eerste berichten hierover in januari 1954 en de veroordeling van Schmidt in oktober 1956 verstreek ruim tweëenhalf jaar. Al die tijd werd het Indonesische 
publiek tegen Nederland opgehitst met de verzinsels van de DPKN. Niemand durfde daar tegen in te gaan. De processen kregen een haast rituele betekenis. Schmidt en Jungschläger waren zondebokken geworden die moesten boeten voor alles wat Indonesië aan Nederland verweet.

De tijd waarin deze schijnprocessen het Nederlandse publiek in beroering brachten duurde niet veel korter: ruim twee jaar van september 1954 tot oktober 1956. Via pers en radio volgde men deze vertoning met spanning, verbijstering en afschuw. Na het overlijden van Jungschläger liet de Nederlandse regering zijn stoffelijk overschot per vliegtuig naar Nederland overbrengen; duizenden woonden daar zijn begrafenis bij. Een half jaar later werd mevrouw Bouman bij haar aankomst in Nederland door duizenden op het vliegveld verwelkomd. Zij was toen de meest bewonderde vrouw van Nederland en werd kort daarna door koningin Juliana ontvangen. De processen droegen in Nederland bij tot grote weerzin tegen het Indonesië van Soekarno. De bereidheid om Nieuw-Guinea daaraan over te dragen werd onder het Nederlandse publiek kleiner dan ooit. Slechts weinigen trokken een tegenovergestelde conclusie, namelijk dat men juist aan Indonesië tegemoet zou moeten komen om de Indonesische bevolking uit haar anti-Nederlandse psychose te verlossen.

\section{De eerste Indonesische parlementsverkiezingen en het laatste parlementaire kabinet}

Toen tijdens de laatste maanden van 1945 in de eerste Republiek Indonesië politieke partijen opgericht werden, verwachtte men algemeen dat in 1946 verkiezingen voor het Indonesische parlement zouden plaatsvinden. Niemand vermoedde toen dat de parlementsverkiezingen nog bijna tien jaar op zich zouden laten wachten.

De voorlopige grondwet van de nieuwe Republiek Indonesië van 1950 bepaalde dat de parlementsleden in algemene verkiezingen gekozen zouden worden volgens een bij wet te bepalen regeling. In afwachting van die verkiezingen kreeg de Republiek een uit benoemde leden bestaand voorlopig parlement. Het duurde tot 1953 voordat dit parlement eindelijk een kieswet vaststelde; daarna verstreken nog twee jaren voordat de uitvoering ervan geregeld was. Die vertraging was voor een belangrijk deel te wijten aan de vrees van veel parlementsleden niet in het gekozen parlement te zullen terugkeren. Dit gold onder meer voor veel parlementariërs uit de voormalige federale gebieden. Als late erfenis van het door Van Mook opgezette federale stelsel waren zowel de niet-Javaanse gebieden als de aristocratische families in het voorlopige parlement oververtegenwoordigd. Daarnaast verwachtten verscheidene politieke partijen er bij verkiezingen op achteruit te zullen gaan. Zo vreesde men in de nationalistische PNI dat het overwicht van de islamitische Masjumi dan nog flink zou toenemen omdat zij de enige partij was met veel aanhang 
buiten de steden. Die vrees werd weliswaar minder toen de traditionalistische Nahdatul Ulama (NU) zich van de meer modernistische Masjumi afsplitste, maar daar stond tegenover dat de positie van de PNI nu steeds meer bedreigd werd door de communistische PKI, de enige partij met een strak geleide partijorganisatie.

Volgens de grondwet moest naast het parlement ook een Konstituante worden gekozen die de definitieve grondwet zou moeten ontwerpen. In april 1955 werd afgesproken dat de verkiezingen voor het parlement gehouden zouden worden op 29 september en die voor de Konstituante op 15 december. De parlementsverkiezingen vonden zonder ernstige incidenten plaats. De opkomst was zeer hoog: ongeveer $90 \%$. De uitslagen weken sterk af van de partijverhoudingen in het voorlopige parlement. Er bleken nog maar vier grote partijen te bestaan. De PNI was de grootste met $22 \%$ van de stemmen; de Masjumi werd tweede met 21\%; daarna volgden de NU met $18 \%$ en de PKI met $16 \%$. Alle andere partijen behaalden hooguit enkele procenten. Zo kreeg Sjahrir's PSI, die lange tijd een belangrijke politieke rol gespeeld had, nu nog maar $2 \%$ van de stemmen. De in december gehouden verkiezingen voor de Konstituante leverden een overeenkomstige uitslag op. Het nieuwe parlement kwam op 26 maart 1956 voor het eerst bijeen.

Sommigen hadden gehoopt dat de vervanging van het benoemde parlement door het gekozen parlement een heilzame invloed zou uitoefenen op het slecht functionerende parlementair-democratische stelsel. Het tegendeel bleek het geval: de verkiezingen hadden de opmaat gevormd naar de ondergang van dit stelsel.

Het nieuwe parlement beschikte over minder politieke ervaring dan zijn voorganger; slechts een kwart van zijn leden had ook deel uitgemaakt van het voorlopige parlement. De langdurige verkiezingsstrijd had de politieke verdeeldheid verscherpt. Ook beklemtoonde de uitslag de verschillen tussen de Javanen en de niet-Javanen (met inbegrip van de Soendanezen). De overgrote meerderheid van de aanhang van PNI, NU en PKI bevond zich op Java en vooral in Midden- en Oost-Java; daarentegen was de Masjumi zowel in de rest van Indonesië als in West-Java de sterkste partij.

In maart 1956 vormde Ali Sastroamidjojo een nieuw kabinet. De leden daarvan kwamen in hoofdzaak uit de PNI, de Masjumi en de NU. Tijdens de formatie hadden deze drie partijen zich verzet tegen aandrang van president Soekarno om ook leden van de PKI in de regering op te nemen. Wel waren nog vijf kleine partijen in het kabinet vertegenwoordigd. Er heerste echter binnen dit kabinet zoveel verschil van mening dat het onvoldoende in staat bleek de grote problemen van het land aan te pakken.

Steeds meer Indonesiërs raakten ontevreden over het partijpolitieke stelsel, dat naar hun mening de verdeeldheid van de natie bevorderde en doelmatig bestuur in de weg stond. Zulke gedachten leefden sterk onder de militairen, 
maar ook bij anderen. Soekarno zelf maakte zich tolk van die gedachten door bij de opening van het parlement te verklaren, dat een echte Indonesische democratie op broederschap moest berusten en niet op westers individualisme.

Er was hier een samenhang met de in deze zelfde tijd gevoerde anti-Nederlandse agitatie. Voor de Tweede Wereldoorlog hadden de meeste Indonesische nationalisten het Nederlandse parlementaire stelsel als politieke norm gehanteerd. In 1938 had dit geleid tot de grote campagne 'Indonesië parlementair', die het verzet tegen het koloniale bestel gekleed had in de eis dat Indonesië een uit en door de bevolking gekozen parlement zou moeten krijgen met een daaraan verantwoordelijke regering (zie pp. 241-2). In oktober-november 1945 had dezelfde norm geleid tot een ingrijpende hervorming van het Republikeinse staatsbestel (zie pp. 421-2). Nu deed zich het omgekeerde voor: het Indonesische parlementaire stelsel kwam juist in een slecht daglicht te staan omdat het met het Nederlandse stelsel overeenkwam.

Wat Soekarno betreft, die had zich nooit kunnen vinden in de rol van een titulair staatshoofd. Weliswaar liet hij het dagelijks bestuur van het land graag aan anderen over, maar hij wilde zelf wel de opperste leider zijn die het laatste woord had. Na de bijeenkomst van het nieuwe parlement bleef hij herhaaldelijk lange tijd uit Indonesië weg. In mei-juli 1956 reisde hij naar de Verenigde Staten en verschillende West-Europese landen, waarbij hij het Amerikaanse parlement mocht toespreken en zowel president Eisenhower als andere staatshoofden mocht ontmoeten. In augustus-oktober 1956 bezocht hij de SovjetUnie en de Chinese Volksrepubliek. Na zijn terugkeer uit China verklaarde hij dat Indonesië in 1945 een ernstige fout gemaakt had door de oprichting van een groot aantal politieke partijen te bevorderen. Indonesië had volgens hem een 'geleide democratie' nodig.

Intussen namen binnen Indonesië de spanningen toe tussen de centrale regering en de gebieden buiten Java. In veel van die gebieden achtte men zich economisch benadeeld ten voordele van het hoofdeiland. Het grootste deel van de Indonesische inkomsten uit export werd door deze gebieden opgebracht, maar die opbrengsten kwamen vooral aan de bevolking van Java ten goede. Daarnaast ergerde men zich aan het centralistische stelsel waardoor men allerlei regionale kwesties niet regionaal kon regelen maar telkens afhankelijk was van besluiten in Djakarta. Tenslotte bestonden er ook psychologische tegenstellingen tussen Javanen en niet-Javanen. De niet-Javanen, met inbegrip van de Soendanezen, vormden $55 \%$ van de bevolking; velen van hen waren beducht voor een samenleving waarin alleen Javanen de dienst zouden uitmaken. Juist als Sumatraan genoot vice-president Hatta veel vertrouwen onder de niet-Javanen.

In de loop van 1956 namen plaatselijke gezagsdragers zowel op Celebes als op Sumatra maatregelen waardoor een groter deel van de export-inkomsten 
aan de exporterende gebieden zelf ten goede kwam. Militaire commandanten en burgerlijke bestuurders werkten hierbij samen. De centrale regering was verdeeld over de vraag hoe men deze regionale insubordinatie moest aanpakken. Vooral binnen de Masjumi bestond begrip voor de regionale wensen.

Op 1 december 1956 trad Hatta af als vice-president. De verschillen van opvatting tussen hem en Soekarno waren te groot geworden. Zijn aftreden gaf een verdere stimulans aan de regionale pogingen om zich aan het gezag van de centrale regering te onttrekken. In de loop van december namen militaire commandanten zowel in Midden-Sumatra als in Noord-Sumatra het bestuur over.

In januari 1957 verlieten de tot de Masjumi behorende ministers het kabinet, waardoor dit zijn meerderheid in het parlement kwijtraakte. Niettemin bleef het afbrokkelende kabinet-Ali nog aan. In februari verklaarde Soekarno dat Indonesië een nieuw regeersysteem nodig had, niet gebaseerd op geïmporteerde westerse normen maar op traditionele Indonesische waarden. Tot die westerse normen rekende hij zowel partijstrijd als besluitvorming bij meerderheid van stemmen, tot de Indonesische tradities behoorden volgens hem zowel wederzijds hulpbetoon als het streven naar overeenstemming door voortgezet overleg. In aansluiting hierop zette hij zijn eigen denkbeelden (zijn konsepsi) over het wenselijke staatsbestel uiteen, waaronder de instelling van een Nationale Raad ter vertegenwoordiging van groepen die onvoldoende in de politieke partijen tot hun recht kwamen.

Begin maart kwam er een nieuwe breuk in de eenheid van Indonesië. De territoriale commandant van Oost-Indonesië, luitenant-kolonel Ventje Sumual, trok de macht over de hele provincie aan zich. Tegelijk publiceerde hij onder de titel Piagam Perdjuangan Semesta Alam (Handvest van de Universele Strijd) een samenvatting van de wensen van de regio's tegenover de centrale regering; zijn opstandige beweging werd daarom wel de Permesta-beweging genoemd. Kort daarna maakte ook de militaire commandant van Zuid-Sumatra zich los van het centrale gezag.

De positie van het kabinet-Ali was onhoudbaar geworden. Op 14 maart 1957 trad het af. Soekarno nam nu in overeenstemming met zijn konsepsi de afbraak van het parlementaire stelsel ter hand. Nog op dezelfde dag kondigde hij voor heel Indonesië de staat van beleg af, wat onder meer inhield dat het burgerlijke bestuur op plaatselijk niveau ondergeschikt werd aan het militaire gezag. Op 8 april vormde hij zelf een extra-parlementair kabinet. Premier hiervan werd de partijloze maar algemeen gerespecteerde oud-minister Djuanda Kartawidjaja. Het kabinet bestond voornamelijk uit leden van de PNI en de NU naast negen partijloze deskundigen; Chaerul Saleh maakte er deel van uit als minister van veteranenzaken. Vervolgens installeerde Soekarno in juli de door hem al aangekondige Nationale Raad. De Raad telde 42 leden, onder wie de chefs van de strijdkrachten en de politie naast vertegenwoordigers 
van groepen zoals arbeiders, boeren, ondernemers, journalisten, kunstenaars, vrouwen, jongeren, veteranen en de 'generatie van 1945'. Soekarno werd zelf voorzitter van deze Raad; Ruslan Abdulgani werd secretaris-generaal.

\section{Volledige breuk van Indonesië met Nederland}

Na de opzegging van de Indonesisch-Nederlandse Unie in het voorjaar van 1956 raakten Indonesië en Nederland steeds verder uit elkaar. Met uitzondering van de communisten hielden vrijwel alle Nederlandse politici vast aan het standpunt, dat de soevereiniteit over westelijk Nieuw-Guinea bij Nederland berustte en moest blijven berusten totdat de inwoners van het gebied in staat zouden zijn over eigen lot te beslissen. Terwijl in juni verkiezingen voor de Tweede Kamer plaatsvonden, speelde de verhouding met Indonesië in de daaraan voorafgaande verkiezingsstrijd geen rol. De daarop gevolgde kabinetsformatie duurde nog veel langer dan destijds in Indonesië gebruikelijk was. Pas in oktober 1956 trad een nieuw kabinet-Drees aan, overigens van dezelfde politieke samenstelling als het vorige en met Luns als minister van buitenlandse zaken. In zijn regeringsverklaring liet dit nieuwe kabinet weten dat het geen initiatieven over Nieuw-Guinea zou nemen.

Een tegengeluid kwam in juli 1956 uit niet-politieke hoek. Een grote protestants-christelijke kerkelijke organisatie, de Generale Synode der Nederlands Hervormde Kerk, publiceerde toen een 'Oproep tot bezinning' waarin zij verklaarde dat Nederland bereid moest zijn af te zien van zijn aanspraken om Nieuw-Guinea alleen op eigen gezag te besturen. Daarbij merkte zij ook op dat Nederland door de handhaving van zijn bestuur de bewoners van dit gebied afsneed van de naburige gebieden in Oost-Indonesië waarmee zij door historische banden verbonden waren. De oproep van de Synode was verrassend omdat juist de protestants-christelijke partijen al sinds 1945 de felste voorstanders waren van een harde lijn in het Indonesië-beleid. De oproep kreeg echter weinig steun. Bij een opiniepeiling verklaarden slechts $10 \%$ van de ondervraagde Nederlanders zich voor een nieuwe poging tot bijleggen van het conflict met Indonesië. Zo kort na de dramatische dood van Jungschläger kon men ook moeilijk anders verwachten.

Zoals vaker werden de verkiezingen gevolgd door een grondwetswijziging (omdat wijzigingen van de Nederlandse grondwet pas van kracht kunnen worden wanneer ze na verkiezingen opnieuw in het parlement behandeld zijn). Sinds 1948 luidde artikel 1 van de grondwet: 'Het Koninkrijk der Nederlanden omvat het grondgebied van Nederland, Indonesië, Suriname en de Nederlandse Antillen'. Bij de grondwetswijziging van 1956 verdween de vermelding van Indonesië uit dit artikel, maar werd tegelijk Nederlands Nieuw-Guinea erin opgenomen. Naar Nederlandse opvatting was dit niets 
meer dan een aanpassing van de tekst aan de nieuwe situatie sinds de soevereiniteitsoverdracht van december 1949. Daarentegen zag men in Indonesië deze grondwetswijziging als een onrechtmatige en vijandige daad.

Intussen was in Indonesië de tweede regering-Ali aangetreden en was de anti-Nederlandse campagne daar nog in hevigheid toegenomen. In massavergaderingen en in persartikelen werd onder meer gepleit voor nationalisatie van de Nederlandse ondernemingen als Nederland bleef weigeren NieuwGuinea over te dragen. In augustus 1956 zette de Indonesische regering zelf een nieuwe stap na de opzegging van de Unie: zij verklaarde de nog bestaande financiële schulden van Indonesië aan Nederland niet langer te erkennen. Een en ander gaf de meeste Nederlandse politici geen aanleiding tot nadenken over de consequenties van het Nieuw-Guineabeleid. In het algemeen dachten deze politici niet dat dit beleid op een ramp in de verhouding met Indonesië afstevende; bovendien meenden ze dat iedere Nederlandse tegemoetkoming het Indonesische radicalisme alleen maar zou versterken. Ook het merendeel van de Nederlandse pers vond dat men niet moest wijken voor Indonesische chantage.

Daarentegen gaven de in Indonesië werkende Nederlandse ondernemers herhaaldelijk uiting aan hun diepe zorgen over de gevolgen van de starre Nederlandse houding. Hun pleidooien voor verandering maakten echter weinig indruk op de Nederlandse politici. Wel werden hun zorgen in Nederland gedeeld door enige leidende figuren van zeer grote ondernemingen. Op initiatief van Paul Rijkens, president-directeur van Unilever, waarschuwden deze figuren in informele contacten met Nederlandse beleidsmakers voor de rampzalige consequenties van het Nieuw-Guineabeleid. De niet-openbare waarschuwingen van deze 'groep-Rijkens' leidden evenmin tot politiek resultaat.

Een openbaar tegengeluid tegen het immobilisme van de Nederlandse politici kwam eind 1956 wederom uit niet-politieke hoek. Een groep van honderdzestien Nederlandse hoogleraren en andere intellectuelen vroeg toen aan de besturen van de zes grote partijen opnieuw om heroverweging van het Nieuw-Guineabeleid. Daarbij wezen zij de opvatting af dat het Nederlands bestuur over Nieuw-Guinea zijn rechtvaardiging vond in een zedelijke roeping. Ook dit verzoek vond geen weerklank.

Intussen nam de verontrusting ernstig toe op de Nederlandse vertegenwoordiging in Djakarta (die sinds de opzegging van de Unie geen Hoge Commissariaat meer was). De staf van die vertegenwoordiging redigeerde een kritisch stuk waarin het bestaande Indonesiëbeleid als legalistisch, passief en inconsequent werd bestempeld en waarin gepleit werd voor het zoeken van een oplossing in bilateraal overleg met Indonesië; daartoe zou herziening van het Nieuw-Guineabeleid noodzakelijk zijn. De staf zond dit stuk in januari 1957 aan minister Luns, met kopieën aan premier Drees en aan de voorzitters van de beide kamers van het parlement. Luns verwierp het stuk 'categorisch'; 
hij bleef bij zijn standpunt dat Nederland ten aanzien van Indonesië geen enkel initiatief moest nemen.

Eveneens in januari 1957 richtten ruim vierhonderd in Indonesië werkende Nederlanders, onder wie achttien hoogleraren, een petitie aan het Nederlandse parlement waarin zij erop aandrongen dat Nederland opnieuw met Indonesië over de status van Nieuw-Guinea zou praten. De petitie was georganiseerd door Willem Oltmans, een Nederlandse journalist die medio 1956 met Soekarno kennis gemaakt had tijdens diens bezoek aan WestEuropa. Oltmans was zich sindsdien gaan inzetten voor doorbreking van de tussen Nederland en Indonesië heersende impasse en kreeg daarbij financiële steun uit de groep-Rijkens. De petitie bleef zonder gevolg.

Op het politieke toneel in Indonesië zelf ging de aandacht in de eerste maanden van 1957 vooral uit naar de tweedracht tussen de centrale regering en enige militaire commandanten in Sumatra en Celebes, die leidde tot het aftreden van het kabinet-Ali, de afkondiging van de staat van beleg en Soekarno's stappen ter verwezenlijking van zijn eigen staatkundige konsepsi. De in april aangetreden regering-Djuanda polste de Nederlandse vertegenwoordiger in Djakarta over de mogelijkheid van toenadering tussen de beide landen, maar de onverzoenlijke standpunten over Nieuw-Guinea lieten hier geen ruimte voor.

In de tweede helft van 1957 ondernam de Indonesische regering een laatste poging om een voor Indonesië gunstige resolutie aangenomen te krijgen in de Algemene Vergadering van de VN. Die zeer korte en gematigde maar door Nederland fel bestreden ontwerp-resolutie hield een uitnodiging aan beide partijen in om hun pogingen tot het vinden van een oplossing van de Nieuw-Guinea-kwestie voort te zetten met bijstand van de Secretaris-Generaal van de VN. In nauwe samenhang met de Indonesische actie in de VN werd in Indonesië zelf de agitatie voor de terugkeer van West-Irian (westelijk NieuwGuinea) sterk opgevoerd. Vooral de politieke partijen PNI en PKI en de daarmee verbonden vakbonden ontplooiden in dit kader allerlei activiteiten. De door Soekarno voorgezeten Nationale Raad stelde voor een grote campagne te organiseren. De regering droeg de coördinatie daarvan op aan een nieuw Comité voor de Bevrijding van West-Irian. De campagne zou drie fasen tellen en telkens een stap verder gaan. Ook de in Indonesië wonende Nederlanders zouden daarbij het doelwit van acties worden.

Op 28 oktober begon de eerste fase met een grote demonstratie voor het gebouw van de Nederlandse vertegenwoordiging, waarbij een pop verbrand werd die het Nederlandse kolonialisme voorstelde. In de daarop volgende dagen werden Nederlandse kantoren en woningen met leuzen beklad en soms geplunderd. Op 10 november begon de tweede fase van de campagne met de bezetting van de twee belangrijkste Nederlandse clubgebouwen in Djakarta. De intimidatie van Nederlanders werd verhevigd; onder meer werden zij niet 
meer geholpen in winkels en markten en niet meer toegelaten tot restaurants en het openbaar vervoer.

Op 29 november vond in New York de stemming over de resolutie plaats. De uitslag was: 41 stemmen voor en 29 stemmen tegen, dus wederom wel een meerderheid maar geen twee derde meerderheid zodat de resolutie niet aangenomen was. De volgende dag steeg de spanning in Indonesië nog verder omdat in Djakarta een aanslag met handgranaten op Soekarno plaatsvond, waarbij hijzelf ongedeerd bleef maar elf anderen om het leven kwamen.

Op 3 december begon de derde fase van de Iriancampagne met een staking van vierentwintig uur in de Nederlandse bedrijven, een landingsverbod voor de Nederlandse luchtvaartmaatschappij KLM en beslag op de vloot van de Nederlandse scheepvaartmaatschappij KPM. Overigens hadden de meeste KPM-schepen de Indonesische wateren al tijdig verlaten; wel bezetten demonstranten het hoofdkantoor van de KPM in Djakarta. Eén dag later verbood de regering alle Nederlandstalige publicaties. Op 5 december verklaarde de minister van justitie (die voordien als rechter het proces tegen Jungschläger had voorgezeten) dat alle Nederlanders Indonesië zouden moeten verlaten. De fatale datum van deze verklaring kreeg onder de Nederlanders als spoedig de naam van 'Zwarte Sinterklaas'. Overigens werd de verklaring later afgezwakt in die zin dat alleen Nederlanders zonder werk zouden worden uitgewezen. Verder werden in deze derde fase steeds meer Nederlandse kantoren en bedrijven door demonstranten bezet; vaak gebeurde dit door vakbondsleden die daar dan rode vlaggen hesen.

De campagne kreeg een radicaler karakter dan de regering had voorzien. In het bijzonder de plotselinge overname van de talrijke grote landbouwbedrijven (de plantages) was de regering niet welkom. Op 9 december verklaarde Soekarno dat acties alleen toegestaan waren als ze door de centrale autoriteiten bevolen waren. Premier Djuanda onttrok de leiding van de Iriancampagne aan het Comité voor de Bevrijding van West-Irian. Generaal Nasution stelde alle plantages onder militair beheer. De rode vlaggen maakten plaats voor het nationale rood-wit. Ook werd er een eind gemaakt aan de anti-Nederlandse boycot. Wel kwamen nu alle Nederlandse bedrijven onder Indonesisch toezicht te staan, met uitzondering van bedrijven waar veel buitenlands kapitaal in geïnvesteerd was zoals Shell en Unilever.

Hoewel de regering de oorspronkelijk aangekondigde uitwijzing van de Nederlanders niet handhaafde, leidde die aankondiging samen met de van bovenaf ontketende intimidatie- en boycotcampagne wel degelijk tot verdrijving van de Nederlandse bevolkingsgroep uit Indonesië. Begin december 1957 telde Indonesië nog bijna vijftigduizend ingezetenen van Nederlandse nationaliteit (minder dan een kwart van het aantal Nederlandse ingezetenen van Indonesië in 1950). De overgrote meerderheid hiervan was in Indonesië geboren; de meesten waren van gemengd Europees-Aziatische afkomst; velen 
waren de bersiap-terreur van 1945 nog niet vergeten. Er kwam nu een grote uittocht op gang. Alleen al in december 1957 vertrokken er negenduizend. Passagiersschepen en vliegtuigen onderhielden een pendeldienst op Singapore; daar werden de evacués in geïmproviseerde kampen ondergebracht om vervolgens naar Nederland door te reizen. Binnen een half jaar trokken vierendertigduizend Nederlanders uit Indonesië weg. Van de resterende Nederlanders was een deel in dienst van zending of missie of van internationale oliebedrijven, terwijl een ander deel bestond uit onbemiddelde Indische Nederlanders zonder reële banden met Nederland.

Eind december 1957 besprak de Nederlandse regering de in Indonesië genomen anti-Nederlandse maatregelen met de Tweede Kamer. Zij kreeg brede instemming met haar mening dat die maatregelen geen uitvloeisel waren van het conflict over Nieuw-Guinea, maar dat dit conflict daartoe slechts tot voorwendsel gediend had. Ook de Nederlandse pers zag in het algemeen in die maatregelen geen gevolgen van de Nederlandse houding over Nieuw-Guinea, maar meende dat het de Indonesische leiders er alleen om ging zich op onwettige manier meester te maken van de Nederlandse ondernemingen. Daarentegen liet de fractie van de PvdA in de Eerste Kamer (waar oud-premier Schermerhorn deel van uitmaakte) begin 1958 een afwijkend geluid horen. Onder meer vond zij het onjuist dat Nederland zich in de VN tegen de resolutie gekeerd had die op overleg over Nieuw-Guinea aandrong.

Overigens betekenden de Indonesische maatregelen tot onderbeheerstelling van de Nederlandse bedrijven nog niet dat ze nu door Indonesië genationaliseerd werden, hoe vaak daar ook in het kader van de anti-Nederlandse agitatie op was aangedrongen. Nog lange tijd hoopte de Indonesische regering ze als onderpand te kunnen gebruiken om Nederland alsnog tot overdracht van Nieuw-Guinea te bewegen. Pas toen in het najaar duidelijk was dat hier geen enkele kans op bestond, besloot zij tot nationalisatie over te gaan. Daarbij verklaarde Soekarno dat de betaling van schadeloosstelling zou worden opgeschort zolang het geschil over Nieuw-Guinea bleef voortbestaan. De voor nationalisatie nodige wetgeving werd eind december 1958 door het parlement aangenomen. De waarde van de door Indonesië genationaliseerde bedrijven wordt op vier à vijf miljard gulden geschat.

Ook ging Indonesië in 1958 nog niet over tot verbreking van de diplomatieke betrekkingen met Nederland. Dit deed het pas op 17 augustus 1960, vijftien jaar na de proclamatie van de Indonesische onafhankelijkheid (zie p. 745).

\section{Ondergang van de democratie in Indonesie}

Op korte termijn bezorgden de anti-Nederlandse acties van december 1957 meer nadeel aan Indonesië dan aan Nederland. De plotselinge uitschake- 
ling van de Nederlandse banken en handelsondernemingen ontwrichtte de Indonesische economie. Het beslag op de KPM, die drie kwart van het interinsulaire scheepvaartverkeer in Indonesië verzorgd had, leidde zowel op Java als elders tot acute voedseltekorten. Hatta en verscheidene andere politici, onder meer van de Masjumi, uitten kritiek op de acties. Zo waarschuwde oud-minister Sjafruddin Prawiranegara, nu president van de Bank Indonesia, dat de Indonesische staat het merendeel van zijn belastinginkomsten uit Nederlandse ondernemingen betrok. De actievoerders keerden zich fel tegen hun critici. Omstreeks de jaarwisseling weken Sjafruddin, Natsir en Harahap naar Sumatra uit omdat zij zich op Java bedreigd voelden. Daar voerden ze in Padang overleg met enige dissidente militaire commandanten.

Het overleg leidde tot een ultimatum van deze groep aan het kabinetDjuanda waarin zij eiste dat dit kabinet zou aftreden, dat er een nieuwe regering zou komen onder Hatta en de sultan van Jogja, en dat Soekarno zich zou beperken tot zijn rol van constitutioneel staatshoofd. Het kabinet verwierp het ultimatum en ontsloeg de betrokken officieren. Daarna riep de Padangse groep op 15 februari 1958 een tegenregering uit die zich aandiende als Pemerintah Revolusioner Republik Indonesia (PRRI, Revolutionaire Regering van de Republiek Indonesië). Sjafruddin trad op als premier. Twee dagen later sloot de Permesta-beweging op Celebes zich bij de PRRI aan.

Ondanks het prestige van Sjafruddin, die in 1948-1949 de Republikeinse noodregering op Sumatra geleid had toen Soekarno en Hatta in Nederlandse gevangenschap verkeerden, genoot deze tegenregering weinig gezag. De rebellen hadden uiteenlopende belangen en motieven en kregen weinig steun van de bevolking. De rebellie was zowel militair als politiek slecht voorbereid. In feite beheerste de PRRI alleen Midden-Sumatra, een deel van NoordSumatra en het noorden van Celebes. In de andere gebieden buiten Java hielden de machthebbers zich afzijdig of bleven zij trouw aan Djakarta. Voorzover de rebellen sympathie verwacht mochten hebben van staf-chef Nasution als Sumatraan kwam die verwachting niet uit. Met vaste hand leidde hij de onderdrukking van de opstand. In maart 1958 gingen de eerste regeringstroepen op Sumatra aan land; begin mei waren daar alle belangrijke steden in hun handen. Daarna landden regeringstroepen in juni op Celebes, waar zij ook al spoedig alle steden beheersten. De leiders van de opstand weken met een deel van hun aanhangers naar de binnenlanden van Sumatra en Celebes uit.

De PRRI was aanvankelijk clandestien gesteund door de Amerikaanse geheime dienst, vooral via Taiwan en de Filipijnen. Naast de levering van wapens omvatte die steun onder meer de uitvoering van luchtaanvallen op Ambon dat een belangrijke basis voor de regeringstroepen vormde. Midden mei werd daar één van de aanvallende vliegtuigen neergeschoten, waarbij de piloot levend in Indonesische handen viel. Hij bleek een Amerikaan te zijn. Voor de Verenigde Staten was dit een ernstige blamage, al ontkende de 
Amerikaanse regering uiteraard iedere betrokkenheid.

De geslaagde onderdrukking van de opstand versterkte Nasution's positie als machtigste man van het land naast Soekarno. Hierbij valt te bedenken dat het leger er al sinds 1945 aanspraak op maakte niet onder maar naast de regering te staan. Na 1950 had het zelfs al tweemaal een minister gearresteerd op beschuldiging van corruptie. De in maart 1957 afgekondigde staat van beleg had aan de militairen bovendien uitdrukkelijke bevoegdheden gegeven om in te grijpen in het burgerlijk bestuur. In december 1957 had Nasution zijn macht verder uitgebreid door de bezette Nederlandse bedrijven onder militair toezicht te stellen. Zijn overwinning op de dissidente officieren op Sumatra en Celebes in 1958 vergrootte nu ook zijn gezag tegenover de territoriale commandanten. Hij benutte de nieuwe situatie om de rationalisatie van de strijdkrachten te hervatten. Veel officieren die hij in dat kader uit de actieve dienst verwijderde kregen nieuwe functies als toezichthouders van onder beheer gestelde bedrijven.

Het mislukte PRRI-avontuur had de positie van de Masjumi ernstig verzwakt. Enige van haar meest prominente leden hadden daar leiding aan gegeven; zelf had zij geweigerd de rebellie te veroordelen; zij zat niet in de regering en gaf geen steun aan Soekarno's staatkundige konsepsi. Daarentegen had de communistische PKI de strijd tegen de rebellie krachtig gesteund en was haar positie nu sterker dan ooit. Bij provinciale verkiezingen in 1957 was al gebleken dat zij kon rekenen op een grotere aanhang dan enige andere partij. Niet alleen beschikte zij over een gedisciplineerde partijorganisatie, maar ook voerde zij de regie over een reeks met haar verbonden arbeiders-, boeren-, vrouwen- en jeugdbonden die miljoenen leden telden. De leiding van de PKI wist echter dat het leger haar vijandig gezind was en zocht daartegen bescherming door zich nauw bij Soekarno aan te sluiten. Zo had zij grote demonstraties georganiseerd tot steun aan Soekarno's konsepsi. Ook was zij de motor geweest van de in december 1957 uitgevoerde bezetting van Nederlandse bedrijven. Soekarno van zijn kant gebruikte de steun van de PKI om niet uitsluitend van het leger afhankelijk te zijn.

Naast de in 1957 in het kader van Soekarno's konsepsi ingestelde Nationale Raad functioneerde intussen nog steeds het in 1955 gekozen parlement. Volgens de grondwet moest na vier jaar, dus in 1959, een nieuw parlement gekozen worden, maar de regering-Djuanda besloot in september 1958 de parlementsverkiezingen uit te stellen. Dit uitstel hield verband met het feit dat de aanhang van de PKI sinds 1955 enorm was toegenomen, waardoor de andere partijen vreesden bij verkiezingen een deel van hun zetels te zullen verliezen. Omgekeerd wilde de PKI de verkiezingen laten doorgaan nu zij mocht verwachten in het nieuwe parlement de grootste partij te worden. Verder bestond naast het parlement ook nog de eveneens in 1955 gekozen Konstituante, die in Bandung vergaderde en het ontwerp voor de definitieve 
grondwet moest opstellen. Weliswaar was in deze Konstituante veel gediscussieerd over het meest wenselijke staatsbestel, maar die discussies waren vastgelopen op de wens van de orthodox-islamitische leden om in de grondwet vast te leggen dat de Indonesische staat op de islam gebaseerd moest zijn. De Konstituante kon deze kwestie niet oplossen omdat zij alleen met een twee derde meerderheid besluiten mocht nemen, terwijl noch de voorstanders noch de tegenstanders van die wens over zo'n meerderheid beschikten.

In deze vastgelopen situatie lanceerde Nasution medio 1958 een nieuw denkbeeld, namelijk helemaal geen nieuwe grondwet opstellen, maar de grondwet van 1950 afschaffen en eenvoudig terugkeren tot de oorspronkelijke grondwet uit augustus 1945. Die grondwet (zie p. 343) voorzag in een tamelijk autoritair staatsbestel en sprak niet over een door verkiezingen samen te stellen parlement. Na veel overleg stemden begin 1959 zowel Soekarno als de PNI, de PKI en de NU met het denkbeeld in. Het leger organiseerde nu een grote propagandacampagne voor 'terugkeer naar 1945' en dreigde met maatregelen tegen persorganen die zich aan 'tendentieuze berichtgeving' schuldig zouden maken.

De voorstanders van herstel van de grondwet van 1945 zagen het liefst dat de Konstituante daar zelf mee zou instemmen. Een probleem daarbij was echter dat die grondwet geen speciale positie aan de islam toekende. De regering-Djuanda meende aan de orthodoxe islamieten tegemoet te kunnen komen door in het besluit tot herstel van de oude grondwet te verwijzen naar een in juli 1945 opgestelde ontwerp-preambule (het zogenaamde Handvest van Djakarta) die wel aan de islam een bijzondere plaats gegeven had maar die uiteindelijk in augustus 1945 niet in de definitieve tekst opgenomen was. In deze vorm werd het voorstel tot terugkeer naar 1945 aan de Konstituante voorgelegd. De manoeuvre mislukte echter, omdat een aantal orthodox-islamitische leden die verwijzing onvoldoende vond. Dank zij hun verzet kreeg het voorstel tot herstel van de grondwet van 1945 bij de uiteindelijke stemming op 2 juni 1959 geen twee derde meerderheid

Terwijl de Konstituante hierover beraadslaagde was Soekarno weer bezig met een wereldreis. Na de fatale laatste stemming kondigde Nasution een tijdelijk verbod op politieke activiteiten af. Eind juni keerde Soekarno in Indonesië terug. Op voorstel van Nasution ontbond hij op 5 juli 1959 de Konstituante en voerde hij bij decreet de grondwet van 1945 weer in. Kort daarna vormde hij een nieuwe regering, nu met hemzelf als minister-president en met Nasution als minister van nationale veiligheid, terwijl Djuanda met de dagelijkse leiding van de regering belast bleef.

Het parlement keurde op 22 juli het herstel van de oude grondwet goed en beroofde zich daarmee van zijn constitutionele basis. De twee jaar eerder ingestelde Nationale Raad werd weer opgeheven, want die moest nu plaats maken voor de in de oude grondwet voorziene Hoge Adviesraad. Eveneens 
in juli werd het aan hoge ambtenaren en aan bestuurders van staatsbedrijven verboden om lid van een politieke partij te zijn.

Deze in juli 1959 in nauw overleg tussen Soekarno en Nasution genomen maatregelen voerden een autoritair staatsbestel in zonder dat duidelijk was bij wie de oppermacht berustte. Nasution had de militaire macht in handen, maar Soekarno bezat het charisma van leider van de onafhankelijkheidsstrijd. Omdat hij niet over een eigen organisatie beschikte gebruikte hij de PKI als tegenwicht tegen de macht van de militairen. Soekarno wilde echter niet alleen macht, maar verlangde ook erkenning als denker en als ideologisch leider van de natie.

Op 17 augustus 1959 gebruikte hij zijn toespraak ter herdenking van de onafhankelijkheidsproclamatie voor een betoog over de ideologische basis van de 'geleide democratie'. Het betoog bevatte een bloemlezing van zijn geliefkoosde thema's, waaronder samenwerking tussen alle revolutionaire krachten, centrale leiding van de politiek en de economie en verwerping van de compromissen van Linggadjati, Renville en de RTC. Deze toespraak vormde het startsein voor een propagandacampagne waarin zijn betoog werd aangeprezen als een politiek manifest (aangeduid met het acroniem Manipol) dat richtlijn moest zijn voor de nationale politiek. Voortaan gold instemming met Manipol als toetssteen voor politieke betrouwbaarheid.

Het gekozen parlement bleef nog tot maart 1960 bestaan en werd toen vervangen door een benoemd parlement, gedeeltelijk bestaand uit vertegenwoordigers van 'functionele groepen', maar zonder leden van de Masjumi of van Sjahrir's PSI. Op grond van de grondwet van 1945 werd bovendien een 'Congres voor Volksoverleg' ingesteld dat ruim zeshonderd leden zou tellen, onder wie alle parlementsleden plus bijna honderd regionale vertegenwoordigers en nog eens ruim tweehonderd vertegenwoordigers van functionele groepen. Tot de verdere in 1960 genomen stappen ter invoering van de 'geleide democratie' behoorden afschaffing van verkiezingen voor regionale en plaatselijke raden en afschaffing van de verantwoordingsplicht van bestuurders tegenover zulke raden.

Tegen deze liquidatie van de democratie rees in Indonesië weinig verzet. Enige politici uit de kring van de Masjumi, de PSI en de christelijke partijen richtten in juni 1960 een Democratische Liga op om zich tegen de 'geleide democratie' te weren, maar deze Liga werd al in juli verboden. In augustus volgde een verbod op de Masjumi en de PSI zelf. De persvrijheid werd steeds verder beknot. In 1961 kwam een perswet tot stand die bepaalde dat de pers de ideologie van de staat moest onderschrijven.

Intussen kwam er geleidelijk een eind aan het in sommige delen van Indonesië gevoerde gewapende verzet tegen de centrale regering. De in maart 1958 op Sumatra uitgeroepen tegenregering, de PRRI, was niet in staat gebleken tot daadwerkelijk tegenspel tegen het door Soekarno en Nasution ingevoerde 
autoritaire stelsel. Haar leiders raakten in een uitzichtloze situatie. Dank zij gunstige capitulatievoorwaarden lieten de meesten van hen zich in de loop van 1961 overhalen tot het staken van de strijd. De capitulerende PRRI-leiders, onder wie de politici Sjafruddin, Natsir en Harahap en de kolonels Kawilarang en Sumual, werden als teruggekeerde verloren zonen verwelkomd. In oktober 1961 volgde zelfs een algemene amnestie voor allen die aan de PRRI-rebellie deelgenomen hadden. Verder leidde een verzoeningsgezinde opstelling van Djakarta medio 1962 ook tot beëindiging van de opstand in Atjeh onder Daud Beureuh. In hetzelfde jaar slaagde het leger er eindelijk in de Darul Islam in West-Java uit te schakelen; haar leider Kartosuwirjo werd gevangen genomen en terechtgesteld. Een jaar later eindigde de guerrillastrijd van de RMS op Ceram met de gevangenneming van haar leider Soumokil. Tenslotte staakte de Darul Islam in Zuid-Celebes de strijd in 1965 nadat haar leider Kahar Muzakkar gesneuveld was.

In januari 1962 werd Soekarno opnieuw het doelwit van een mislukte aanslag. Op beschuldiging van betrokkenheid bij die aanslag werden daarna verscheidene zeer prominente politici gearresteerd, onder wie Sjahrir, Rum, Anak Agung, sultan Hamid, Sjafruddin, Natsir en Harahap. De beschuldigingen berustten op een bizarre complottheorie. De gearresteerden waren in feite zuiver politieke gevangenen; hun gevangenneming bezegelde de ondergang van de democratie in Indonesië.

\section{Militaire confrontatie over Nieuw-Guinea}

De in najaar 1957 in Indonesië ontketende campagne voor de 'bevrijding van West-Irian', die was uitgelopen op de verdrijving van de Nederlandse bevolking en de inbeslagneming van de Nederlandse ondernemingen, had geen verandering gebracht in de opstelling van de Nederlandse regering in de kwestie-Nieuw-Guinea. De Indonesische machthebbers richtten zich sindsdien vooral op versterking van de Indonesische strijdkrachten om Nederland ertoe te brengen het gebied los te laten. De snelle onderdrukking van de opstand op Sumatra en Celebes in het voorjaar van 1958 liet zien dat die strijdkrachten al in staat waren tot omvangrijke operaties, maar voor verovering van West-Nieuw-Guinea zou een veel groter militair potentieel nodig zijn.

Al sinds 1954 werkte Indonesië stelselmatig aan de versterking van zijn militaire uitrusting. Onder meer bestelde het toen marineschepen en ander oorlogsmaterieel in Italië, Groot-Brittannië en West-Duitsland. Ook wilde het graag Amerikaanse wapens aankopen, maar de Verenigde Staten leverden die slechts op kleine schaal. Daarentegen bood de Sovjet-Unie sinds 1956 grote leningen aan voor de aanschaf van militair materieel. De leveringen op basis hiervan kwamen in 1958 goed op gang. Daarbij kreeg Indonesië onder 
meer de beschikking over Russische bommenwerpers en straaljagers. Ook deed het militaire aankopen in andere communistische landen zoals Polen en Tsjechoslowakije. Naast de spectaculaire versterking van de Indonesische luchtmacht leidden de Oost-Europese leveringen tot versterking van de landmacht met onder meer tanks, helikopters, kanonnen en handwapens en tot uitbreiding van de marine met tientallen oorlogsschepen waaronder ook onderzeeboten.

De Verenigde Staten leverden tot 1958 slechts weinig militair materieel aan de Indonesische strijdkrachten. Het Amerikaanse Aziëbeleid richtte zich bovenal op het voorkomen van een verdere uitbreiding van het communisme, dat het vasteland van China en het noorden van Korea en Vietnam al beheerste. De sterke opkomst van de communistische beweging in Indonesië en de welwillende opstelling van Soekarno tegenover die beweging leidden dan ook tot grote ongerustheid in Washington. Daarom gaf de Amerikaanse geheime dienst in de eerste helft van 1958 militaire steun aan de opstand van de PRRI op Sumatra en Celebes. De snelle onderdrukking van die opstand door het Indonesische regeringsleger bewees echter dat deze dienst op het verkeerde paard gewed had. De mislukking van dit avontuur was voor Washington extra pijnlijk door de gevangenneming van de Amerikaanse piloot op Ambon. In de zomer van 1958 besloot de Amerikaanse regering tot een radicale koerswijziging. Om te voorkomen dat Indonesië naar het communistische kamp zou overgaan vestigde zij nu al haar hoop op het regeringsleger onder Nasution. Daarom besloot zij over te gaan tot zowel economische als militaire steun aan Indonesië. Het in dat kader door de VS geleverde militaire materieel was voornamelijk voor de Indonesische landmacht bestemd en omvatte geen zware wapens.

De Amerikaanse steun betekende niet dat Indonesië nu naar het westelijke kamp overging. Indonesië trok profijt van de 'koude oorlog' tussen het oostelijk en het westelijk blok. De Russische regeringsleider Chroesjtsjov bezocht Indonesië in mei 1960 en Nasution bracht in december 1960 een bezoek aan Moskou. De Sovjet-Unie bleef Indonesië steunen met grote militaire kredieten, die vooral de versterking van de Indonesische marine en luchtmacht ten goede kwamen. Zowel Amerikaanse als Russische instructeurs trainden nu Indonesische militairen in het gebruik van het door hun regeringen geleverde materieel.

In Nederland maakte men zich tot het eind van de jaren vijftig weinig zorgen over het vooruitzicht van een militaire krachtmeting om Nieuw-Guinea. De meeste politici beseften wel dat Nederland het gebied niet tegen een grootscheepse aanval zou kunnen verdedigen, maar ze dachten dat de Verenigde Staten het nooit zo ver zouden laten komen. Vooral minister Luns was hiervan overtuigd. Overigens kwam er in deze periode een belangrijke wijziging in de samenstelling van de Nederlandse regering. Conflicten tussen de PvdA en de 
KVP leidden in december 1958 tot het aftreden van Drees en de andere PvdAministers. Er kwam nu een eind aan de coalitie van PvdA en KVP die sinds 1946 de basis van de Nederlandse regering gevormd had. In maart 1959 vonden parlementsverkiezingen plaats waarbij de PvdA twee zetels verloor en de VVD zes zetels won. In mei trad een kabinet aan van de confessionele partijen KVP, ARP en CHU samen met de VVD. Het nieuwe kabinet werd geleid door de KVP-politicus J.E. de Quay; Luns bleef minister van buitenlandse zaken.

Begin 1960 besloot het kabinet-De Quay de Nederlandse strijdmacht in Nieuw-Guinea, die ruim tweeduizend man telde, sterk uit te breiden en ook tientallen straaljagers en andere vliegtuigen naar het gebied over te brengen. Bovendien besloot men het grootste schip van de Nederlandse marine, het vliegkampschip 'Karel Doorman', in mei samen met twee torpedobootjagers op een wereldreis te sturen waarbij het Nieuw-Guinea zou bezoeken en daar tegelijk een deel van de nieuwe vliegtuigen zou afleveren. Daarna zou het eskader onder meer Japan bezoeken ter viering van het 350-jarig bestaan van Japans-Nederlandse betrekkingen. Deze wereldreis voor 'vlagvertoon' werd al eind maart aangekondigd.

In Indonesië wekte het reisplan woedende reacties. De Indonesische regering veroordeelde het zenden van het eskader als een bedreiging van de Indonesische veiligheid; de pers noemde het een oorlogsdaad. Er vonden antiNederlandse demonstraties plaats en op 6 mei 1960 bestormden honderden demonstranten het gebouw van de Nederlandse diplomatieke vertegenwoordiging in Djakarta. Weliswaar lieten ze daar het personeel ongemoeid, maar ze sloegen de inventaris stuk, vernielden het portret van koningin Juliana en verbrandden de Nederlandse vlag. De Nederlandse regering reageerde verontwaardigd, maar zag niet van het reisplan af. De 'Karel Doorman' vertrok op 31 mei. Als represaille sloot Indonesië zijn territoriale wateren voor alle schepen onder Nederlandse vlag. Overigens betaalde de Indonesische regering wel een vergoeding aan Nederland voor de in het gebouw van de vertegenwoordiging aangerichte schade.

De vlagvertoonreis van de 'Karel Doorman' liet zien in welk een internationaal-politiek isolement Nederland door zijn conflict met Indonesië beland was. Egypte had al vroeg duidelijk gemaakt dat de schepen niet door het Suezkanaal zouden mogen varen; de reis ging dan ook om Afrika heen. De regering van Madagascar gaf echter geen toestemming voor een bezoek aan dat eiland. Bij aankomst in Australië werd het eskader door de Australische havenarbeiders geboycot. Nadat het eskader gedurende augustus NieuwGuinea bezocht had zette het koers naar Japan, maar de Japanse regering trok nu haar toestemming in voor het afgesproken feestelijke bezoek zodat de schepen rechtsomkeert moesten maken. Bovendien gaf de Filipijnse regering geen toestemming voor doorvaart door haar gebied. Uiteindelijk keerde het eskader via Australië, Nieuw-Zeeland en Zuid-Amerika naar Nederland terug. 
De vlagvertoonreis had nog een ander gevolg. In zijn rede op 17 augustus 1960 hekelde Soekarno de houding die Nederland die aan de dag had gelegd door de 'Karel Doorman' naar West-Irian te sturen en maakte hij bekend dat Indonesië daarom de diplomatieke betrekkingen met Nederland verbrak.

\section{Ontdooiing van het Nederlandse standpunt over Nieuw-Guinea}

In 1951 had de Nederlandse regering de kwestie van de toekomst van NieuwGuinea voor onbepaalde tijd 'in de ijskast' gezet. Van niet-politieke kant werd in Nederland vooral sinds 1956 meer dan eens gepleit voor herziening van het Nieuw-Guineabeleid. Niettemin hielden de meeste Nederlandse politici nog lang vast aan het standpunt dat de soevereiniteit over het gebied bij Nederland berustte en moest blijven berusten totdat de bevolking ervan in staat zou zijn zelf over haar staatkundige lot te beslissen, dat er geen sprake kon zijn van onderhandelingen met Indonesië over de toekomstige status van het gebied en dat Nederland geen enkele vorm van gemengd bestuur of gedeelde verantwoordelijkheid voor het gebied zou mogen aanvaarden. Het duurde tot 1958 voordat er enige beweging in dit standpunt kwam.

Het in 1950 door Nederland met grote verwachtingen begonnen afzonderlijke bestuur over westelijk Nieuw-Guinea had toen acht jaar geduurd. De redenen die destijds voor het vasthouden van dit gebied waren aangevoerd hadden hun overtuigingskracht grotendeels verloren. Het gebied had zich niet geleend voor volksplantingen van Indische Nederlanders (de reden die minister Jonkman in december 1946 had aangevoerd om de mogelijkheid open te laten voor afscheiding van Nieuw-Guinea van de rest van Indonesië). De voorspellingen over lucratieve exploitatie van bodemschatten waren niet uitgekomen. De gedachte dat Nederland met Nieuw-Guinea als basis voor zijn marine een invloedrijke rol in de Pacific zou kunnen spelen (een vooral door Luns gekoesterde gedachte) was een hersenschim gebleken. Zo hadden de Verenigde Staten in 1951 een defensieverdrag met Australië en NieuwZeeland gesloten, het ANZUS-pact, maar Nederland was hier niet bij betrokken. Vervolgens was in 1954 op Amerikaans initiatief een bondgenootschap tot stand gekomen onder de naam Southeast Asian Treaty Organization (SEATO), met als leden de Verenigde Staten, Groot-Brittannië, Frankrijk, Australië, Nieuw-Zeeland, de Filipijnen, Thailand en Pakistan, maar ook hier werd Nederland buiten gehouden.

Het enige overgebleven motief voor de voortzetting van het Nederlandse gezag over Nieuw-Guinea was het begeleiden van de Papoeabevolking op de weg naar zelfbeschikking, een door Nederland zelf bedachte taak die het geen andere baten dan morele bevrediging opleverde. De gedachte dat Nederland zich nog decennia lang van deze belangeloze taak zou moeten kwijten begon 
sommige politici te benauwen, ook omdat Nederland het hierin zonder hulp van anderen moest stellen. Dit laatste had al eerder geleid tot nadenken over mogelijkheden van samenwerking met andere landen bij de vervulling van die taak. De eerste vorm van 'internationalisering' die in aanmerking leek te komen was samenwerking met Australië, dat immers de oostelijke helft van Nieuw-Guinea bestuurde. Wat de toekomst van dat gebied betreft dacht men in Australië wel eens aan een zelfstandig samengaan van Oost- en West-Guinea, bij voorkeur samen met een aantal ten oosten daarvan gelegen eilanden in een onafhankelijke 'Melanesische federatie'. Ook in Nederland bestond belangstelling voor die gedachte. Op 6 november 1957 maakten de Australische en de Nederlandse regering bekend dat zij hun bestuur over Oost- en West-Guinea zouden gaan coördineren met het oog op de verwezenlijking van het zelfbeschikkingsrecht voor de bevolking van de beide gebieden. De bekendmaking geschiedde net voordat in Indonesië de tweede fase begon van de nationale campagne voor de 'bevrijding van West-Irian'. Deze Australisch-Nederlandse samenwerking wekte daar verontrusting omdat het denkbeeld van een Melanesische federatie waar heel Nieuw-Guinea deel van zou uitmaken wel eens een gunstig onthaal zou kunnen krijgen binnen de Verenigde Naties.

De eind 1957 in het kader van de Indonesische campagne voor de 'bevrijding van West-Irian' ondernomen anti-Nederlandse acties lieten het denken in Nederland niet geheel onberoerd. Wel hadden velen zich in eerste aanleg aangesloten bij de opvatting van de regering dat die acties geen uitvloeisel van het conflict over Nieuw-Guinea waren maar dat dit conflict daartoe slechts tot voorwendsel gediend had. Niettemin begonnen sommigen zich af te vragen of het werkelijk nodig geweest was in Indonesië het lot van vijftigduizend Nederlanders plus Nederlandse investeringen ter waarde van vier à vijf miljard gulden op te offeren voor het heilige doel van het behoud van Nieuw-Guinea. Vooral binnen de PvdA groeide ontevredenheid over de onwrikbaarheid van het regeringsstandpunt. Haar fractie in de Eerste Kamer liet al in januari 1958 blijken geen bezwaar te hebben tegen overleg met Indonesië over Nieuw-Guinea. De PvdA-fractie in de Tweede Kamer vroeg in september aan de regering de mogelijkheid te onderzoeken om Nieuw-Guinea tot een trustschapgebied van de Verenigde Naties te maken. Ook maakte zij bezwaar tegen gedwongen uitzending van dienstplichtige militairen naar het gebied.

De val van het kabinet-Drees in december 1958 en het aantreden van het kabinet-De Quay in mei 1959 maakten het gemakkelijker de kwestie NieuwGuinea 'uit de ijskast' te halen. Nu de PvdA in de oppositie was hoefde zij zich niet meer gebonden te voelen tot steun aan het officiële standpunt om de regeringscoalitie niet in gevaar te brengen. Verder was het vooral Drees geweest die halsstarrig aan dat standpunt had vastgehouden, terwijl de nieuwe premier, De Quay, persoonlijk meer voor internationalisering voelde. 
Ook enige andere ministers uit zijn kabinet twijfelden aan de houdbaarheid van het officiële standpunt. Niettemin verklaarde de nieuwe regering het Nieuw-Guineabeleid van het vorige kabinet te zullen voortzetten. Bovendien besloot zij de ontwikkeling van de bevolking in de richting van zelfbeschikking aanzienlijk te versnellen. Onder meer bereidde zij daartoe de instelling voor van een vertegenwoordigend lichaam dat in meerderheid uit Papoea's zou bestaan, de Nieuw-Guinea Raad. Ook richtte zij een Papoea Vrijwilligers Korps op. In april 1960 presenteerde zij een tienjarenplan voor de ontwikkeling van Nieuw-Guinea, dat ook instemming van de PvdA kreeg.

Voor het overige werden de discussies in Nederland over Nieuw-Guinea in 1960 sterk beïnvloed door de voortgaande versterking van het Indonesische militaire potentieel, de toenemende Indonesische infiltraties op het eiland en de ongelukkig verlopen reis van de 'Karel Doorman'. Nadat Soekarno op 17 augustus bekendgemaakt had dat zijn land de diplomatieke betrekkingen met Nederland verbrak, hield hij eind september een bijzonder dreigende toespraak tot de AVVN in New York. Hij noemde daarin de Nederlandse bezetting van westelijk Nieuw-Guinea een koloniaal zwaard dat op het hart van Indonesië gericht was en de wereldvrede bedreigde. In Nederland gingen nu steeds meer stemmen op ten gunste van internationalisering van Nieuw-Guinea in die zin dat de verantwoordelijkheid niet meer uitsluitend op Nederland zou rusten. Ook het kabinet-De Quay besloot deze weg in te slaan. In het najaar deed minister Luns al een kleine stap in die richting door in de AVVN te verklaren dat Nederland bereid was zijn beleid in Nieuw-Guinea te onderwerpen aan onderzoek en beoordeling door de VN.

De meeste Nederlandse politici, met inbegrip van die van de PvdA, waardeerden het dat er beweging zat in de opstelling van de Nederlandse regering. Maar 'internationalisering' kon nog van alles betekenen. Voor Luns was het slechts een middel om Indonesië buiten Nieuw-Guinea te houden. Streven naar internationalisering in die zin kon echter het acute gevaar van oorlog over Nieuw-Guinea niet bezweren. Tegen die achtergrond ondernamen andere Nederlanders dan politici in 1961 diverse activiteiten ten gunste van een vreedzame oplossing van het conflict. Zulke activiteiten werden ook bevorderd door verklaringen van prominente Indonesiërs dat hun land weliswaar in staat was Nederland met geweld uit Nieuw-Guinea te verdrijven, maar dat zij een oorlog liever zouden willen vermijden. Zo zei de Indonesische minister van buitenlandse zaken, Subandrio, in februari 1961 dat zijn land zich niet zou verzetten tegen deelname van de $\mathrm{VN}$ aan het zoeken van een oplossing mits van tevoren zou vaststaan dat Nieuw-Guinea na verloop van één of twee jaar bij Indonesië zou terugkeren.

Tot de hier bedoelde activiteiten van Nederlandse niet-politici behoorde een in april 1961 verschenen manifest tegen het Nieuw-Guineabeleid van de regering, ondertekend door een honderdtal intellectuelen en kunstenaars. 
Het manifest wees er onder meer op dat dit beleid de Papoea's opvoedde in vijandschap tegen Indonesië terwijl zij daar in de toekomst toch mee zouden moeten samenleven. Buiten de openbaarheid voerden leden van de groepRijkens in het eerste halfjaar van 1961 herhaaldelijk overleg met Indonesische vertegenwoordigers. Deze groep van Nederlandse 'captains of industry' (zie p. 734) onderhield zowel contact met president Soekarno als met premier De Quay en beschikte bovendien over relaties met de Amerikaanse regering. Ook in de kringen van kerk en zending zocht men naar mogelijkheden om een oor$\log$ met Indonesië te voorkomen. Verder spande professor F.J.F.M. Duynstee, een conservatieve katholiek, zich bijzonder voor een vreedzame oplossing in. Generaal Nasution sprak medio 1961 tijdens een bezoek aan Europa zowel met Duynstee als met Nederlanders uit kerkelijke kringen. In diezelfde tijd berichtte de journalist Oltmans in het weekblad Vrij Nederland uitvoerig over de activiteiten van de groep-Rijkens.

In de loop van het jaar stelden ook enige belangrijke Nederlandse kranten zich steeds kritischer op tegenover het officiële Nieuw-Guineabeleid. Het meest gezaghebbende dagblad, de Nieuwe Rotterdamse Courant, sprak zich in augustus zelfs uitdrukkelijk uit voor overdracht van Nieuw-Guinea aan Indonesië.

Intussen ging de Nederlandse regering door met haar programma van versnelde ontwikkeling van de Papoeabevolking naar zelfstandigheid. Op 5 april 1961 werd de Nieuw-Guinea Raad geïnstalleerd, bestaande uit dertien benoemde en zestien gekozen leden. Later in het jaar kreeg het gebied zelfs een eigen vlag en een eigen volkslied. In Indonesië zag men een en ander als de voorbereiding van een pseudo-onafhankelijke Papoeastaat. De hierbij door Nederland gevolgde methodiek kwam sterk overeen met die waarmee het in 1947-1949 een aantal deelstaten in Indonesië opgericht had.

Daarnaast besloot de regering bij de Verenigde Naties een eigen voorstel tot internationalisering in te dienen. Luns zette dit voorstel in september 1961 in de AVVN uiteen; journalisten noemden het sindsdien het 'plan-Luns'. De ontvangst van dit plan door de Nederlandse politici liet zien dat hun opstelling ten aanzien van Nieuw-Guinea in het algemeen achterbleef bij de veranderende opvattingen in niet-politieke kring. Het plan kreeg brede steun in het parlement, ook van de PvdA. Een verrassende uitzondering hierop deed zich voor bij de ARP die altijd een harde lijn tegenover Indonesië had voorgestaan. Onder invloed van de protestants-christelijke zending pleitte zij nu voor een open gesprek met Indonesië over Nieuw-Guinea en keerde zij zich tegen het Nederlandse internationaliseringsvoorstel.

Dit voorstel stelde voorop dat Nederland bereid was zijn bestuur over Nederlands Nieuw-Guinea over te dragen aan een door de VN op te richten internationaal orgaan, mits het recht van zelfbeschikking van de bevolking gewaarborgd zou zijn. Met het oog daarop zou de AV eerst een commissie 
moeten instellen die naar het gebied zou gaan om daar onder meer de mogelijkheid te onderzoeken van een onder VN-toezicht te houden volksstemming over de wensen van de inwoners. Vervolgens zou die commissie de mogelijkheid van een interim-bestuur onder gezag van de VN moeten bezien. Als zo'n interim-bestuur er zou komen, zou Nederland zijn soevereiniteit over het gebied aan de bevolking afstaan.

Het voorstel werd in najaar 1961 in de AVVN gesteund door Australië en Nieuw-Zeeland maar kreeg verder vrijwel geen bijval, terwijl het wel scherpe kritiek uitlokte. Ook de Amerikaanse delegatie nam er afstand van. Minister Subandrio waardeerde de Nederlandse bereidheid om de aanspraak op soevereiniteit over West-Irian op te geven, maar verzette zich tegen de plannen tot stichting van een Papoeastaat. Hij zei dat Indonesië de stichting van zo'n staat evenmin zou dulden als het de stichting van de RMS op Ambon geduld had. Zou Nederland zijn plannen tot afscheiding van West-Irian doorzetten, dan betekende dat oorlog. Aan de andere kant verklaarde hij ook dat Indonesië bereid was tot een oplossing met een overgangsperiode waarin de VN een rol zou spelen.

De Nederlandse delegatie zag er van af het plan-Luns in stemming te brengen. Wel stemde zij voor een voorstel van een aantal Afrikaanse landen waarin Indonesië en Nederland werden aangespoord om met elkaar over de toekomst van Nieuw-Guinea te onderhandelen zonder afbreuk te doen aan de zelfbeschikking van de bevolking. Dit voorstel haalde echter geen twee derde meerderheid.

De mislukking van het Nederlandse initiatief in de AVVN versterkte binnen Nederland de gedachte dat een radicale wijziging van het NieuwGuineabeleid nodig was. In december 1961 riepen zowel de rooms-katholieke bisschoppen als het bestuur van de Nederlands Hervormde Kerk op tot rechtstreeks overleg met Indonesië.

\section{Beëindiging van het conflict en overdracht van Nieuw-Guinea}

De hoofddoelstelling van het beleid van de Verenigde Staten met betrekking tot Azië was het voorkomen van een verdere uitbreiding van het communisme, dat het vasteland van China en het noorden van Korea en Vietnam al beheerste. De mogelijkheid dat Indonesië naar het communistische kamp zou overgaan was dan ook een bron van grote zorg in Washington. Om zo'n ontwikkeling tegen te gaan vestigde de Amerikaanse regering sinds medio 1958 haar hoop op het Indonesische leger onder generaal Nasution en gaf zij Indonesië zowel militaire en economische steun. Het tussen Indonesië en Nederland bestaande conflict over Nieuw-Guinea was in dat verband een storende factor. Er was de Amerikaanse regering dus veel aan gelegen dit conflict 
de wereld uit te helpen, maar onder president Eisenhower ondernam zij geen actieve pogingen hiertoe. Dit werd anders toen John F. Kennedy in januari 1961 als president aantrad.

Kennedy beschouwde Nieuw-Guinea als een gevaarlijke crisishaard. De situatie was in 1960 ook steeds ernstiger geworden door de voortgaande opbouw van de Indonesische strijdkrachten, door de verbreking van de diplomatieke betrekkingen van Indonesië met Nederland en door de steeds radicaler anti-westerse opstelling van Soekarno. Kennedy vreesde dat de Nederlandse Nieuw-Guineapolitiek Indonesië in de armen van Moskou dreef. Zou er over Nieuw-Guinea werkelijk oorlog uitbreken dan zou Indonesië niet alleen door landen als India en Pakistan en de Arabische landen gesteund worden, maar dan zou de Sovjet-Unie zich zeker actief aan de kant van Indonesië scharen, en dat tegen Nederland dat in de NAVO met de Verenigde Staten verbonden was. Het was een nachtmerriescenario dat zelfs tot een wereldoorlog zou kunnen leiden. Om dit gevaar af te wenden zou men een procedure moeten vinden om Nederland ertoe te brengen Nieuw-Guinea los te laten zodat het gebied met Indonesië verenigd kon worden.

Eén van de eerste dingen die Kennedy ondernam was het scheppen van een persoonlijke band met zijn Indonesische collega. Op zijn uitnodiging bracht Soekarno in april 1961 een bezoek aan Amerika, waarbij Kennedy zijn gast met veel egards behandelde. Kort daarvoor sprak hij uitvoerig met Luns over Nieuw-Guinea. Luns zei dat Nederland openstond voor iedere vorm van trustschap, maar het zelfbeschikkingsrecht vooropstelde. Kennedy beval hem aan over de mogelijkheden van internationalisering overleg te plegen met het State Department. In de volgende maanden sprak de Nederlandse ambassade in Washington hier inderdaad herhaaldelijk over met het State Department. Het vervolgens in september 1961 door Nederland gelanceerde internationaliseringsvoorstel week echter af van de aan Amerikaanse kant levende gedachten. Het plan-Luns was in de eerste plaats bedoeld om de weg te bereiden voor een onafhankelijke Papoeastaat. Daarentegen dachten de Amerikaanse beleidsmakers aan een scenario dat juist zou moeten leiden tot hereniging van Nieuw-Guinea met Indonesië, via een tussenfase waarin het Nederlandse bestuur plaats zou maken voor een interim-bestuur van de VN maar met volle toegang van Indonesië tot het gebied voordat de bevolking gelegenheid zou krijgen tot een keuze over haar staatkundige toekomst.

Nadat in november 1961 in de AVVN gebleken was dat Nederland met zijn plan vrijwel alleen stond, vond de Amerikaanse regering dat het tijd was om rechtstreeks overleg tussen de Nederlandse en de Indonesische regering tot stand te brengen. Begin december vroeg zij aan de beide regeringen hoe zij behulpzaam kon zijn bij het vinden van een oplossing. Luns wilde erkenning van het recht op zelfbeschikking van de Papoea's als prealabele voorwaarde stellen voor een gesprek met Indonesië, maar het kabinet besloot hiervan af 
te zien. Eind december deelde de Nederlandse regering aan Washington mee dat zij bereid was tot een open gesprek met Indonesië, bij voorkeur in aanwezigheid van een derde partij, en dat het zelfbeschikkingsrecht daarbij voor Nederland 'uitgangspunt' zou zijn.

De Amerikaanse vraag aan Indonesië was vergezeld gegaan van een persoonlijke brief van Kennedy waarin hij Soekarno dringend vroeg om af te zien van het gebruik van geweld. Het conflict over Nieuw-Guinea was inderdaad een gevaarlijker stadium ingegaan. In Indonesië was aangekondigd dat Soekarno op 19 december 1961 zijn 'laatste bevel' voor de bevrijding van WestIrian zou geven. Op die dag hield hij een rede waarin hij een algemene mobilisatie aankondigde en zijn volk opdroeg de vorming van een marionettenstaat in West-Irian te verhinderen en ervoor te zorgen dat de Indonesische vlag boven West-Irian zou worden gehesen. Ook stelde hij een speciaal commando in voor de bevrijding van het gebied. In de afgelopen jaren was het Indonesische militaire potentieel wel sterk uitgebreid, vooral met schepen en vliegtuigen, maar pas nu bouwde men daaruit een geïntegreerde aanvalsmacht op. Het commando kwam onder leiding te staan van kolonel Suharto, die tot generaal-majoor bevorderd werd en zijn hoofdkwartier vestigde in Udjung Pandang (het vroegere Makassar).

Op de dag waarop Soekarno zijn rede uitsprak zond de secretaris-generaal der Verenigde Naties, U Thant, telegrammen aan de Indonesische en de Nederlandse regering waarin hij zijn grote zorg over de gevaarlijke situatie uitsprak en er bij beide partijen op aandrong samen naar een vreedzame oplossing te zoeken.

De initiatieven van de Amerikaanse regering en de secretaris-generaal der VN leidden tot een waaier van verkennende gesprekken in Washington, New York, Djakarta en Den Haag. Onder andere bezocht Robert Kennedy, een broer van de president, zowel Soekarno als de Nederlandse regering. Uiteindelijk werd men het er over eens dat Indonesië en Nederland onder auspiciën van de $\mathrm{VN}$ en zonder prealabele voorwaarden geheim overleg zouden voeren in Amerika onder leiding van een Amerikaan die zou optreden als vertegenwoordiger van U Thant. Dit overleg begon op 20 maart 1962 in een landhuis in de buurt van Washington onder leiding van Ellsworth Bunker, een gepensioneerde Amerikaanse diplomaat. De Nederlandse delegatie werd geleid door de ambassadeur in Washington, J.H. van Roijen; de Indonesische delegatie door Adam Malik, die toen ambassadeur in Moskou was. Nadat Van Roijen in 1949 voor een goede afwikkeling had mogen zorgen na de mislukking van de Nederlandse politiek tegenover de Republiek, viel hem nu dus een soortgelijke taak toe na het volledige bankroet van het Nederlandse NieuwGuineabeleid.

Het op 20 maart geopende overleg tussen Indonesië en Nederland leidde pas op 15 augustus tot een akkoord. Daarmee duurde dit overleg onnodig 
lang, want in feite ging het om een eenvoudige zaak: Nederland moest westelijk Nieuw-Guinea loslaten zodat het gebied met Indonesië verenigd kon worden. Dat bracht enige praktische problemen mee, maar die kwamen in het overleg pas laat aan de orde. Daarentegen werd het overleg van begin af aan door prestigekwesties overheerst. De Amerikaanse regering had in de door haar voorgestane oplossing twee elementen opgenomen om de vernedering voor Nederland te verzachten: ten eerste geen rechtstreekse overdracht van het bestuur door Nederland aan Indonesië maar indirecte overdracht via een tijdelijk VN-bestuur, en ten tweede een gelegenheid voor de bevolking van het gebied tot vrije keuze over haar staatkundige toekomst na een aantal jaren Indonesisch bestuur. Het eerste element hield geen rekening met de belangen van die bevolking, want die zouden met rechtstreekse overdracht door Nederlandse aan Indonesische functionarissen meer gebaat zijn dan met een tussenbewind door tijdelijk personeel in VN-dienst dat noch Nederlands noch Indonesisch kende. Ook het tweede element was pure symboliek ten behoeve van Nederlands gezichtbehoud, want het was politiek ondenkbaar dat de Indonesische machthebbers de bevolking van West-Irian werkelijk zouden toestaan zich van Indonesië af te scheiden. Een andere belangrijke prestigekwestie die het overleg bemoeilijkte was de Indonesische wens dat de roodwitte vlag nog voor het eind van het jaar in West-Irian zou worden gehesen.

Het was zowel aan Luns als aan Soekarno te wijten dat tussen de opening van het overleg en de sluiting van het akkoord veel tijd verstreek. Luns wilde lange tijd niet inzien dat zijn Nieuw-Guineabeleid mislukt was en belemmerde daardoor een vlotte afwikkeling. Soekarno wilde lange tijd niet definitief kiezen tussen diplomatie en strijd als methode om West-Irian met Indonesië te herenigen. Hij voerde de militaire confrontatie voortdurend op. Al in januari had dit er onder meer toe geleid dat een Indonesische motortorpedoboot voor de kust van Nieuw-Guinea door de Nederlandse marine tot zinken gebracht werd. Om de druk op Nederland te verhogen werden Indonesische militairen niet alleen per boot op Nieuw-Guinea en de bijbehorende eilanden aan land gezet, maar werden daar van april tot augustus ook honderden parachutisten neergelaten. Intussen ging de opbouw van de eigenlijke aanvalsmacht onverminderd voort.

Het op 20 maart geopende overleg werd al na drie dagen afgebroken omdat Adam Malik in Indonesië nadere instructies wilde halen. In afwachting van de hervatting van het overleg stelde ambassadeur Bunker een schets voor een akkoord op die hij begin april aan beide partijen voorlegde. Deze schets, die bekend is geworden als het 'plan-Bunker', hield het volgende in. Nederland zou het bestuur over westelijk Nieuw-Guinea overdragen aan een tijdelijk gezagsorgaan onder de secretaris-generaal van de VN, dat het gebied minimaal een jaar en maximaal twee jaar zou besturen. Tijdens die periode zouden eerst de Nederlandse functionarissen worden vervangen door personeel in 
VN-dienst en zou vervolgens dit personeel worden vervangen door Indonesische functionarissen, zodat het bestuur bij het eind van de periode volledig bij Indonesië zou berusten. Verder zou Indonesië samen met de VN regelingen treffen om de bevolking van het gebied na een nog nader te bepalen aantal jaren gelegenheid te geven voor een vrije keuze. Het woord 'soevereiniteit' kwam in het hele stuk niet voor. President Kennedy beval dit plan-Bunker in persoonlijke brieven aan de beide regeringen aan.

In Nederland was intussen de PvdA overstag gegaan en had zij zich uitgesproken voor overdracht van Nieuw-Guinea aan Indonesië. Dit leidde er echter toe dat de regering en de meerderheid in het parlement zich nog steviger vastbeten in het zelfbeschikkingsrecht van de Papoea's. Pas op 26 mei verklaarde de regering zich bereid het plan-Bunker te aanvaarden als een basis voor verdere onderhandelingen. De Indonesische regering had zich al eerder in die zin geuit, overigens zonder in te stemmen met de in het plan aangegeven termijnen. Na de Nederlandse bereidverklaring hield Soekarno de heropening van het overleg echter nog anderhalve maand op. Pas op 13 juli konden Van Roijen en Adam Malik hun gesprek hervatten. In deze tweede ronde van het overleg nam soms ook minister Subandrio er aan deel.

De nieuwe overlegronde voltrok zich in een zeer gespannen sfeer. De Indonesische aanvalsmacht werd in Oost-Indonesië in gereedheid gebracht. Deze strijdmacht telde ongeveer dertigduizend man en beschikte over dertig oorlogsschepen, honderdtwintig transportschepen en honderden vliegtuigen. Het grootste marineschip was een moderne Russische kruiser die de naam 'Irian' kreeg. Intussen had Nederland nog enige versterkingen naar Nieuw-Guinea overgebracht, zodat de Nederlandse verdediging daar nu ongeveer tienduizend man telde. De onderhandelaars raakten in tijdnood, want men moest rekening houden met oorlog als geen akkoord bereikt zou zijn voor 17 augustus, de dag waarop in Indonesië de onafhankelijkheidsproclamatie van 1945 herdacht werd. In afwijking van het plan-Bunker wilde de Indonesische delegatie de fase van het VN-tussenbestuur nu eenvoudig overslaan en het bestuur rechtstreeks van Nederland op Indonesië laten overgaan. In tweede aanleg wilde zij het VN-intermezzo zo kort laten duren dat Indonesië in elk geval nog in 1962 zelf het bestuur zou overnemen. Deze voorstellen hielden kennelijk verband met de herhaalde publieke uitspraken van Soekarno, dat West-Irian nog voor het eind van het jaar met Indonesië herenigd zou worden.

Dank zij door zowel secretaris-generaal U Thant als president Kennedy ondernomen stappen kon de Indonesische delegatie tot een meer coöperatieve houding worden gebracht. Daardoor wisten de twee delegaties eind juli toch overeenstemming te bereiken over alle belangrijke punten. Die overeenstemming hield in dat het interim-bestuur van de VN zou duren van 1 oktober 1962 tot 1 mei 1963, dat de eerste fase al op 31 december 1962 zou eindigen 
en dat de bevolking uiterlijk in 1969 zou mogen kiezen of zij wel of niet met Indonesië verbonden wilde blijven. De manier waarop zij die keuzevrijheid zou kunnen uitoefenen zou te zijner tijd nader worden bepaald in overleg met vertegenwoordigende lichamen.

Overigens sprak men tijdens deze tweede ronde ook over een reeks praktische kwesties, waartoe de beide delegaties werden uitgebreid met onder meer militaire en financiële deskundigen. Hierbij rezen geen ernstige moeilijkheden. Het overleg vond nu niet meer in een afgelegen landhuis plaats maar deels in Washington deels in New York. De delegatieleiders bespraken het ontwerpakkoord (waar het woord 'soevereiniteit' niet in voorkwam) begin augustus met hun regeringen. Met U Thant werd onder meer nog een regeling getroffen over het voeren van de nationale vlaggen tijdens het VN-tussenbestuur: naast de VN-vlag zou van 1 oktober tot 31 december de Nederlandse vlag waaien en van 1 januari 1963 tot 1 mei de Indonesische vlag.

Terwijl in de tweede week van augustus in New York met behulp van het VN-secretariaat alle voorbereidingen werden getroffen om tot ondertekening van het akkoord over te gaan, begon in het oosten van Indonesië de aanvalsmacht toch in actie te komen en maakte Soekarno plotseling bezwaar tegen de vlaggenregeling. Uiteindelijk ging hij ermee akkoord mits de Indonesische vlag al in de avond van 31 december gehesen zou worden. Met één dag vertraging vond op 15 augustus 1962 de ondertekening van het akkoord plaats namens de beide regeringen. Tegelijk kwamen die regeringen overeen hun diplomatieke betrekkingen te zullen hervatten. Op 17 augustus kon Soekarno in zijn rede op Onafhankelijkheidsdag triomfantelijk bekendmaken dat Nederland gecapituleerd had. Daarbij verklaarde hij lijnrecht in strijd met de in New York ondertekende tekst dat de daarin overeengekomen keuzevrijheid geen extern zelfbeschikkingsrecht maar alleen een intern zelfbeschikkingsrecht inhield.

$\mathrm{Na}$ de ondertekening wikkelden verschillende organen in recordtempo de procedures af die nodig waren om de overeenkomst van New York in werking te stellen. De Nederlandse regering legde de overeenkomst op 25 augustus voor aan het parlement. Bij de parlementaire behandeling nam zij het standpunt in dat geen formele handeling nodig was om de Nederlandse soevereiniteit over westelijk Nieuw-Guinea te beëindigen. Zowel de Tweede als de Eerste Kamer keurde de overeenkomst met overweldigende meerderheid goed. Op 20 september werd de overeenkomst in New York namens de Indonesische en de Nederlandse regering bekrachtigd. De volgende dag nam de AVVN een door deze beide regeringen ingediende resolutie aan waarin de secretaris-generaal gemachtigd werd om de taken uit te voeren die hem bij de overeenkomst waren toevertrouwd. Dat betrof in de eerste plaats de instelling van de United Nations Temporary Executive Authority (UNTEA), het VN-bestuursorgaan dat westelijk Nieuw-Guinea tot 1 mei 1963 zou besturen.

Het VN-secretariaat had intussen voorbereidend werk gedaan. De Indiase 
generaal Rikhye, militair adviseur van U Thant, was al in augustus naar WestIrian en Indonesië vertrokken voor overleg met de plaatselijke autoriteiten en voor toezicht op het militaire bestand dat sinds 18 augustus van kracht was. De regering van Pakistan stelde aan de VN een korps van vijftienhonderd militairen ter beschikking dat begin oktober aankwam om de Nederlandse militairen af te lossen. Hoofd van de UNTEA werd een Perzische diplomaat, Djalal Abdoh. Maar toen de UNTEA op 1 oktober het bestuur formeel van Nederland overnam, had zij voor de uitoefening van dat bestuur pas ruim veertig niet-Indonesische en niet-Nederlandse functionarissen in dienst. De meeste Nederlandse ambtenaren vertrokken spoedig en tegelijk stroomden Indonesische ambtenaren en vrijwilligers binnen. Al in november stemde de UNTEA ermee in dat Indonesische officieren de leiding van de politie overnamen. Ook verschenen er steeds meer Indonesische militairen. Op 31 december hielden Indonesische troepen een parade door de straten van Hollandia ter gelegenheid van het hijsen van de rood-witte vlag. Hoewel het bestuur over West-Irian formeel nog vier maanden bij de VN bleef berusten, oefende de UNTEA haar bestuur in die periode al voornamelijk met Indonesische functionarissen uit.

Op 1 mei 1963 droeg de VN het bestuur formeel aan Indonesië over. Eliëzer Bonay, een voormalig Papoealid van de Nieuw-Guinea Raad, werd de door Djakarta benoemde gouverneur van de provincie Irian Barat. Op 4 mei heette hij Soekarno welkom die aan boord van de kruiser 'Irian' in het voormalige Hollandia aankwam. De president sprak als gebruikelijk een volksmenigte toe en liet zijn gehoor vele malen 'merdeka' roepen. Ook legde hij een krans bij een monument voor de gesneuvelde parachutisten. Eindelijk mocht Soekarno de nationale vrijheidsstrijd als voltooid beschouwen, nu het Indonesische gezag zich uitstrekte over het hele gebied dat hij altijd had omschreven als 'van Sabang tot Merauke'.

\section{Aantekeningen bij hoofdstuk IX}

\section{Literatuuroverzicht}

De politieke ontwikkelingen in Indonesië gedurende de jaren 1950-1962 worden globaal beschreven in diverse algemene geschiedwerken over dit land zoals $A$ history of modern Indonesia door M.C. Ricklefs (1991). Meer gedetailleerde studies zijn The decline of constitutional democracy in Indonesia door H. Feith (1962) over de periode 1950-1957 en The transition to guided democracy; Indonesian politics 1957-1959 door D.S. Lev (1964). Ook het derde deel van Verguisd en vergeten; Tan Malaka, de linkse beweging en de Indonesische Revolutie, 1945-1949 door H.A. Poeze (2007) bevat veel bijzonderheden over dit tijdvak. Een veelomvattend maar beknopter overzicht is te vinden in Indonesië; kolonialisme, onafhankelijkheid, neo-kolonialisme door J. Pluvier (1978).

De Nederlandse kant van de relatie tussen Indonesië en Nederland gedurende dit 
tijdvak is grondig beschreven in Den Haag-Djakarta; De Nederlands-Indonesische betrekkingen 1950-1962 door H. Meijer (1994).

Een afzonderlijk aspect van die relatie was het geschil over westelijk Nieuw-Guinea. Dit heeft aanleiding gegeven tot een overvloed van geschriften, deels van polemische, deels van historische en deels van journalistieke aard. Op de grens van de eerste en de tweede categorie bevinden zich twee publikaties van Nederlandse hoogleraren in het publiekrecht, namelijk Nieuw Guinea als wereldprobleem door B.V.A. Röling (1958) en Nieuw Guinea als schakel tussen Nederland en Indonesië door F.J.F.M. Duynstee (1961). De belangrijkste geschiedkundige studies zijn The trauma of decolonization; The Dutch and West New Guinea door A. Lijphart (1966), De kwestie Nieuw Guinea; Aspecten van buitenlands beleid en militaire macht door P.B.R. de Geus (1984), Misleiding of zelfbedrog; Een analyse van het Nederlandse Nieuw Guinea-beleid aan de hand van gesprekken met betrokken politici en diplomaten door R. Gase (1984), The West New Guinea debacle; Dutch decolonization and Indonesia 1945-1962 door C.L.M. Penders (2002) en Een daad van vrije keuze; De Papoea's van westelijk Nieuw-Guinea en de grenzen van het zelfbeschikkingsrecht door P.J. Drooglever (2005).

De politieke situatie na de soevereiniteitsoverdracht

Deze kenschets van de sfeer in begin 1950 berust allereerst op mijn persoonlijke herinnering. Over Hirschfeld zie Meijer 1994. Over de ontbinding van het KNIL zie Den Hoed 1990, over de Molukse KNIL-militairen zie Manuhutu 1990.

Op 29 januari 1950 stierf Panglima Besar Sudirman, de leider van de Republikeinse strijdkrachten tijdens de vrijheidsstrijd. Hoewel de term Panglima Besar op zichzelf niets anders dan 'opperbevelhebber' betekent, was die titel zo nauw met Sudirman's persoon verbonden geraakt dat dezelfde titel nooit meer aan latere opperbevelhebbers toegekend is.

\section{De APRA-affaire}

Zie onder meer NIB XX:757-62, 786, 840-2, 854-5, Meijer 1994:100-22 en De Moor 1990 en 1999. De achtergrond van deze affaire is altijd onduidelijk gebleven. Ik vermoed dat het APRA-plan in eerste aanleg niet van Westerling zelf afkomstig was, maar van personen binnen de Nederlandse militaire inlichtingendienst. Voor de uitroeping van de Negara Islam Indonesia door Kartosuwirjo zie Van Dijk 1981:92. De eveneens tegen de RVI strijdende Chaerul Saleh werd in maart 1950 door de TNI gevangen genomen. Sultan Hamid is in april 1953 veroordeeld tot tien jaar gevangenisstraf met aftrek van voorarrest; hij is in 1956 vrijgelaten.

Ontmanteling van de federale structuur

Zie Kahin 1952:446-52, Feith 1962:58-77 en Meijer 1994:155-7.

Het parlement van de RVI kwam op 20 februari 1950 voor het eerst bijeen. Bij die gelegenheid werd ook een voorlopige versie getoond van het staatswapen van het nieuwe Indonesië, met onder meer de mythische vogel Garuda, de spreuk 'Bhinekka tunggal ika' (Eenheid in verscheidenheid) en een schild met symbolen voor de vijf onderdelen van de Pantja Sila.

Mislukte muiterij in Makassar

Zie Van Kaam 1977:105-12, Van der Meulen 1981:11-25, Chauvel 1990:331-46, Kawila- 
rang 1993:162-3 en Bouman 1995:335-40.

Andi Abdul Aziz is in april 1953 veroordeeld tot veertien jaar gevangenisstraf met aftrek van voorarrest; een half jaar later is die straf verminderd tot acht jaar; hij is in 1956 vrijgelaten.

Uitroeping van de Republiek der Zuid-Molukken

Zie Van Kaam 1977:113-30, Van der Meulen 1981:27-32, 45-56, Chauvel 1990:347-63 en Kawilarang 1993:181-2.

Opheffing van het KNIL

Zie Den Hoed 1990, Manuhutu 1990:35-8 en Meijer 1994:197-200. Over J. Tahija zie Van Kaam 1977:96, 106-7.

Herstel van de Indonesische eenheidsstaat

Zie Kahin 1952:460-7 en Feith 1962:68-9, 92-9. Over de zienswijze van Hirschfeld zie Meijer 1994:157. Voor een Engelse vertaling van de Indonesische grondwet van 1950 zie A.B. Nasution 1992:487-510.

Herovering van Ambon

Zie Van Kaam 1977:131-52, Van der Meulen 1981:141-6, Bosscher en Waaldijk 1985:10755, Chauvel 1990:387-91 en Kawilarang 1993:182-96.

\section{Impasse over Nieuw-Guinea}

Zie Feith 1962:155-65, Lijphart 1966:163-77, Anak Agung 1973:79-89, De Geus 1984:608, Meijer 1994:255-9, 287-90 en Drooglever 2005:186-203.

De Nederlandse regering nam de hier genoemde maatregelen op basis van een op 21 december 1949 door het Nederlandse parlement aangenomen 'Machtigingswet Nieuw-Guinea' (zie ook NIB XX:652, noten 12 en 13). De uitspraak dat Nederland met die maatregelen als eerste het Unieverdrag heeft geschonden is ontleend aan oudminister De Geus (zie De Geus:1984:52).

Van Maarseveen werd in maart 1951 minister van binnenlandse zaken in het nieuwe kabinet; hij stierf echter in november van dat jaar.

Overbrenging naar Nederland van Ambonese ex-KNIL-militairen

Zie Bosscher en Waaldijk 1985:53-60, Manuhutu 1990:39-42 en Meijer 1994:239.

Mislukking van de Indonesisch-Nederlandse Unie

Zie Meijer 1994:271-87, 299-307, 341-4, 386-96, 440-5, 491-518 en Groeneboer 1993:4603.

De eerste jaren parlementaire democratie in Indonesië

Voor een uitvoerig overzicht van de binnenlands-politieke ontwikkelingen in Indonesië in 1950-57 zie Feith 1962. Voor meer beknopte overzichten zie Pluvier 1978:112-95 en Ricklefs 1991:237-56. Voor de samenstelling van het parlement zie Feith 1962:93-5, 128. Voor een overzicht van de politieke partijen zie Feith 1962:122-45.

De grondwet van de RVI van 1949 had in artikel 122 uitdrukkelijk bepaald dat het parlement in zijn voorlopige samenstelling noch het kabinet noch individuele minis- 
ters tot aftreden kon dwingen. Een overeenkomstige bepaling was welbewust niet opgenomen in de voorlopige grondwet van 1950. Daardoor kon het stelsel voldoen aan de politieke norm van de in 1939 door de vrijheidsbeweging gelanceerde campagne 'Indonesië parlementair' (zie pp. 241-2).

Het onderscheid tussen 'bestuurders' en 'volksleiders' heb ik ontleend aan de onderscheiding tussen 'administrators' en 'solidarity makers' in Feith 1962:33-4, 113-22.

\section{Verscherping van het conflict over Nieuw-Guinea}

Zie Duynstee 1961:203-19, Lijphart 1966:177-91, Anak Agung 1973:95-177, Meijer 1994:296-9, 342-5, 373-7, 397-8, 404-5, 425-6, 457-73 en Drooglever 2005:208-37, 3089. Over de reis van Frans Goedhart zie Goedhart 1953. Over de behandeling van de kwestie Nieuw-Guinea in de AVVN in 1954-1957 zie BZ 1955, BZ 1956, BZ 1957, BZ 1958.

\section{Anti-Nederlandse processen in Diakarta}

Zie Goedhart 1953:111-3, Beynon 1956, Schmidt 1961, Meijer 1994:431-8, 459-62, 46776, 541-2, 554-5 en Penders 2002:226-36. Over de islamitische opstandige bewegingen in West-Java, Zuid-Celebes en Atjeh zie Van Dijk 1981:97-108, 166-95, 300-20. Voor een Nederlands pleidooi om aan Indonesië tegemoet te komen zie Beynon 1956:190-201.

Schmidt werd in maart 1959 in het geheim aan Nederland overgedragen nadat de Nederlandse regering smeergeld betaald had en nadat een Indonesisch hof van beroep zijn gevangenisstraf verlaagd had tot de tijd die hij al in gevangenschap doorgebracht had. Toen dit bekend werd volgden in Indonesië woedende reacties. De regering-Djuanda ontsloeg de procureur-generaal die de zaak behandeld had en verklaarde tegen gerechtshoven te zullen optreden als hun vonnissen de nationale veiligheid in gevaar brachten. Zie Feith 1962:331 en Meijer 1994:571.

De eerste Indonesische parlementsverkiezingen en het laatste parlementaire kabinet

Zie Feith 1962:424-40, 462-555, Lev 1964:1-42, Pluvier 1978:158-68 en Ricklefs 1991:250-

9. Zie over Soekarno's buitenlandse reizen in 1956 ook Giebels 2001:122-39. Over Chaerul Saleh zie Poeze 2007:1702-4, 1724-5, 1787-90.

Tot de gekozen parlementsleden behoorde de voormalige Nederlander Poncke Princen die kandidaat gesteld was door een bond van oud-militairen, de Ikatan Pendukung Kemerdekaan Indonesia (IPKI, Bond van Ondersteuners van de Indonesische Onafhankelijkheid). Overigens zat hij van medio 1958 tot eind 1959 gevangen wegens kritiek op de strijdkrachten en raakte hij toen in gevangenschap bevriend met Schmidt (zie Schmidt 1961:221-2 en Princen 1995:161-2).

Volledige breuk van Indonesië met Nederland

Zie Duynstee 1961:236-71, Lijphart 1966:200-9, Pluvier 1978:186-9, De Geus 1984:87-94, Meijer 1994:545-64, 575-94 en Drooglever 2005:308-11. Zie over de behandeling van de kwestie-Nieuw-Guinea in de AVVN in 1957 ook Röling 1958:45-78 en BZ 1958.

\section{Ondergang van de democratie in Indonesië}

Zie Feith 1962:578-608, Lev 1964, Pluvier 1978:179-82, 189-213 en Ricklefs 1991:262-70. Voor de discussie in de Konstituante zie A.B. Nasution 1992. Over de beëindiging van de opstandige bewegingen zie Van Dijk 1981:124-6, 215-7, 334-9. 
De eind 1957 begonnen aanstelling van beroepsofficieren tot toezichthouders over de onder beheer gestelde Nederlandse bedrijven heeft de opmaat gevormd naar de vervlechting van het Indonesische officierscorps met de nationale economie die kenmerkend zou worden voor de later onder president Soeharto ingevoerde 'Nieuwe Orde'.

\section{Militaire confrontatie over Nieuw-Guinea}

Zie Duynstee 1961:271-2, 279, 298-302, 310-1, De Geus 1984:95-6, 104-10, 115-27, Meijer 1984:606-8, Van Holst Pellekaan, De Regt en Bastiaans 1989 en Drooglever 2005:35271. Het vliegkampschip 'Karel Doorman' was genoemd naar de commandant van een geallieerd marine-eskader die in februari 1942 gesneuveld was in de zeeslag met de Japanse invasievloot in de Javazee (zie p. 263).

\section{Ontdooiing van het Nederlandse Nieuw-Guinea-beleid}

Zie Duynstee 1961:278-98, 329-40, Lijphart 1966:223-76, De Geus 1984:111-3, 130-2, 139-41, 147-153 en Drooglever 2005:379-416. Voor de behandeling van het plan-Luns in de AVVN in 1961 zie BZ 1962.

De uitspraak dat het lot van vijftigduizend Nederlanders en investeringen ter waarde van vier à vijf miljard gulden zijn opgeofferd voor het heilige doel van het behoud van Nieuw-Guinea is afkomstig van oud-minister De Geus (De Geus 1984:93).

De ommezwaai van de ARP in 1961 was des te opmerkelijker omdat die in het parlement werd bekendgemaakt door de fractievoorzitter Bruins Slot (tevens hoofdredacteur van het dagblad Trouw), een politicus die in 1946-48 een fervent pleitbezorger was geweest van militair optreden tegen de Republiek.

Een heldere en evenwichtige analyse van zowel de Nederlandse als de Indonesische motieven ten aanzien van Nieuw-Guinea is in december 1957 geschreven door de volkenrechtsgeleerde B.V.A. Röling, nadat hij als lid van de Nederlandse delegatie in de AVVN de behandeling van het onderwerp had bijgewoond (Röling 1958). Zijn conclusie was dat Nederland er goed aan zou doen Nieuw-Guinea snel aan Indonesië over te dragen. Röling, die hoogleraar in Groningen was, trad in 1958 ook als spreker over dit onderwerp op. Wegens zijn stellingname werd hij voor landverrader uitgemaakt en had hij herhaaldelijk politiebescherming nodig. Zijn stellingname had nog een ingrijpender gevolg. In 1959 kwam de leerstoel volkenrecht vrij aan de Rijksuniversiteit in Leiden, de meest prestigieuze Nederlandse leerstoel op dit vakgebied. De juridische faculteit in Leiden had Röling hiervoor unaniem voorgedragen. De Nederlandse regering besloot echter een jurist van mindere statuur (die zelfs nog niet gepromoveerd was) op deze leerstoel te benoemen.

\section{Beëindiging van het conflict en overdracht van Nieuw-Guinea}

Zie BZ 1963, Lijphart 1966:277-84, De Geus 1984:154-92, Penders 2002:332-75 en Drooglever 2005:417-91, 571-99. Over de rol van Luns zie Huydecoper van Nigtevegt 1990. Over de rol van Kennedy zie Koster 1991. Over de militaire confrontatie zie Van Holst Pellekaan, De Regt en Bastiaans 1989.

Wat betreft het achterwege laten van een formele beëindiging van de soevereiniteit over westelijk Nieuw-Guinea verklaarde de Nederlandse regering op 12 september 1962 onder meer: 'Wanneer Nederland krachtens de overeenkomst op 1 oktober de uitoefening van zijn soevereine bevoegdheden staakt, komt daarmee de facto en 
de jure een einde aan de Nederlandse soevereiniteit' (BZ 1963:134). Ik vind dit een absurde redenering. Op grond van de sinds eind 1949 door alle Nederlandse regeringen gehuldigde (maar door mij niet gedeelde) theorie dat de Nederlandse soevereiniteit over het gebied gehandhaafd was gebleven, zou Nederland die soevereiniteit volgens mij wel degelijk met een formele daad hebben moeten beëindigen. Dit had bijvoorbeeld de vorm kunnen krijgen van een door koningin Juliana te ondertekenen, door het kabinet te contrasigneren en in het Staatsblad te publiceren verklaring, dat het Koninkrijk met ingang van 1 oktober 1962 afstand deed van de soevereiniteit over het gebied. 